UNIVERSIDADE DE SÃO PAULO

ANGELA GONÇALVES DE SOUZA

As várias figurações de Thânatos na poesia de Sophia de Mello Breyner Andresen 
ANGELA GONÇALVES DE SOUZA

\section{As várias figurações de Thânatos na poesia de Sophia de Mello Breyner Andresen}

Dissertação apresentada ao Programa de Mestrado em Literatura Portuguesa da Faculdade de Filosofia Letras e Ciências Humanas da Universidade de São Paulo, como requisito parcial à obtenção do título de Mestre em Literatura Portuguesa.

Orientadora Profa. Dra. Mônica Muniz de Souza Simas, Universidade de São Paulo - USP

São Paulo

Faculdade de Filosofia, Letras e Ciências Humanas da USP

Departamento de Literatura Portuguesa 
2011

\section{FOLHA DE APROVAÇÃO}

SOUZA, A. G. As várias figurações de Thânatos na obra de Sophia de Mello Breyner Andresen. Dissertação apresentada ao Departamento de Letras Clássicas e Vernáculas Programa de Literatura Portuguesa da Universidade de São Paulo para obtenção de título de Mestre em Literatura Portuguesa.

Aprovado em:

\section{Banca examinadora}

Prof. Dra. Sofia Sousa e Silva Instituição: UFRJ - RJ

Julgamento:

Assinatura:

Prof. Dra. Ana Maria Domingues de Oliveira Instituição: UNESP - ASSIS

Julgamento:

Assinatura:

\section{Suplentes}

Prof. Dra. Ida Maria Santos Ferreira Alves Instituição: UFRJ - RJ

Julgamento:

Assinatura:

Prof. Dra. Lilian Jacoto

Instituição: USP - SP

Julgamento:

Assinatura:

Prof. Dra. Marlise Vaz Bridi

Instituição: USP - SP

Julgamento:

Assinatura: 
"A morte? Mas a morte está dentro da vida." (Bernardo Soares - Livro do Desassossego)

"Se temos mesmo de morrer, será mais suave morrermos esclarecidas." (Coro das servas - Íon) 


\section{AGRADECIMENTOS:}

Ao meu pai, Silvério, e à minha mãe, Iracema, pelo infinito amor e pelo exemplo de vida.

À minha irmã Edna, pelo incentivo e amor, e à memória de minha irmã, Cristina.

Aos meus sobrinhos Vivian, Rafael e Kamila, por todo o apoio.

A meu querido cunhado e amigo Valdemar.

Ao tio Toni e à tia Helena, pela acolhida.

Aos meus amigos, em especial ao Douglas, à Carla, à Regina e à Cíntia pela força constante.

À minha orientadora Mônica Muniz de Souza Simas, pelos ensinamentos, pela deferência, pela amizade e pela paciência.

Aos professores do Departamento de Literatura Portuguesa da USP, em especial à Mônica Muniz de Souza Simas, à Marlise Vaz Bridi e à Lilian Jacoto.

Aos professores do Departamento de Literatura Grega, em especial à Adriane da Silva Duarte. Ao professor de Literatura Brasileira Roberto Ventura. 


\section{RESUMO}

Sophia de Mello Breyner Andersen, Porto 1919 - Lisboa, 2004, importante poeta portuguesa do século XX, absorveu, em sua obra, uma influência muito intensa da cultura clássica grega. Em seus livros de poesia, apresentou um constante e intenso diálogo com alguns mitos da Grécia Antiga.

Esta dissertação parte da constatação de que o mito de Thânatos, nas suas mais variadas figurações, dialoga intensamente com a poesia de Sophia Andresen, criando uma atmosfera melancólica e nostálgica.

O presente trabalho divide-se em três capítulos: Thânatos: O Tempo e a Memória, Thânatos: Noite e Thânatos: do Minotauro as Fúrias.

Palavras-chave: Sophia Breyner Andersen, Literatura Portuguesa, poesia portuguesa do século XX, mitos, Thânatos, análise poética. 


\begin{abstract}
Sophia de Mello Breyner Andresen, Porto, 1919 - Lisboa 2004 was an important Portuguese poet from the 20th Century. She absorbed a very intense influence from the classic Greek culture in her work. In her poetry books she presents us a constant and intense dialog with some myths from the Ancient Greece.
\end{abstract}

This dissertation begins from the findings that the myth of Thanatos, in its most various pictures, maintains an internal dialog with Sophia Andresen's poetry, building up a nostalgic and melancholic atmosphere.

This paper is divided in three chapters - Thanatos: Time and Memory, Thanatos: Night and Thanatos: Minotaur and the Furies.

Key-words: Sophia de Mello Breyner Andersen, Portuguese Literature, $20^{\text {th }}$ Century Portuguese poetry, myths, Thanatos, poetic analysis. 


\section{SUMÁRIO}

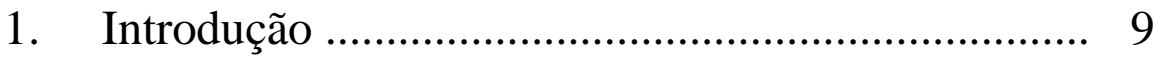

2. Thânatos: O Tempo e a Memória .......................... 19

3. Thânatos e a Noite ................................................. 50

4. Thânatos: do Minotauro às Fúrias ......................... 79

5. O deixar a casa ................................................. 125

6. Bibliografia ....................................................... 136

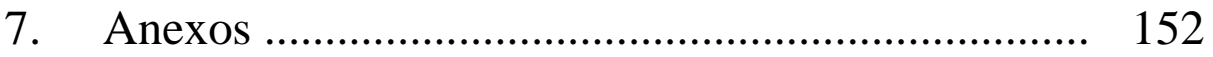

Anexo A - Thânatos 152

Anexo B - Mito, Thânatos e Psicologia 154

Anexo C - O polvo na cerâmica grega 155

Anexo D - O homem Vitruviano 156

Anexo E - Clitemnestra 158

Anexo F - Electra 159

Anexo G - Metamorphoses $\quad 160$ 


\section{INTRODUÇÃO}

Este estudo pretende analisar, a partir de um determinado grupo de poemas, quais as possíveis implicações que as variadas imagens do mito de Thânatos $^{l}$ podem assumir na poesia de Sophia de Andresen.

Sabemos que não é um assunto fácil, mas a lição que o eu lírico, nesses versos do poema "O Sol, o muro, o mar", do livro Ilhas $^{2}$ nos ensina é que não devemos desviar os olhos para o que nos causa temor:

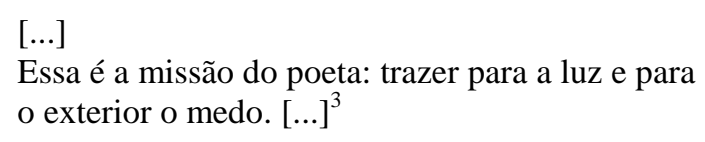

Sophia de Mello Breyner Andresen nasceu na cidade do Porto, a 6 de novembro de 1919, e faleceu em Lisboa a 2 de Julho de 2004. É uma das mais importantes poetas portuguesas da segunda metade do século XX. Data de 1944 seu primeiro livro, de nome Poesia. Sua obra é composta de livros de poesias, de contos, de histórias infantis, de ensaios e de traduções, entre elas o drama Medeia ${ }^{4}$, do poeta grego Eurípedes.

Sua poesia tem como marca a busca incessante do real e da união entre todas as coisas do mundo, herança do romantismo do poeta Rainer Maria Rilke. Segundo Joaquim Manuel Magalhães, a poesia de "Sophia Andresen insere-se dentro de uma intenção lírica insistentemente referencial." ${ }^{, 5}$ É a partir do intenso diálogo com a cultura do mundo clássico, principalmente o mundo grego antigo, que este estudo pretende analisar a presença de Thânatos na obra andresiana. Alberto Lacerda, no ensaio "Sophia de Mello à cerca da sua

\footnotetext{
${ }^{1}$ Verifica Anexo - A.

${ }^{2}$ Vamos utilizar, para este trabalho, as re-edições póstumas dos livros individuais de Sophia de Mello Breyner Andresen. Não é intuito desta dissertação discutir critérios de edição.

${ }^{3}$ ANDRESEN, Sophia de Mello Breyner. Ilhas. Lisboa: Caminho, 2004, p.44.

${ }^{4}$ EURÍPEDES, Medeia. Tradução de Sophia de Mello Breyner Andresen. Lisboa: Caminho, 2006.

${ }^{5}$ MAGALHÃES, Joaquim Manuel. Rima pobre. Lisboa: Presença, 1999, p. 41.
} 
poesia", diz que esta "é de raiz trágica, pois tem a lucidez constante e agudíssima das antinomias. Sua fome de absoluto é um desejo de realização, e não de fuga." ${ }^{6}$ Este estudo busca saber como se desenvolve este encontro corajoso da poesia andresiana com as mais variadas figurações de Thânatos.

Thânatos $^{7}$ é a personificação da morte na mitologia grega, mas não o seu agente. Faz parte da primeira geração dos deuses, filho da divindade Nýx (a Noite) e Érebo, (as Trevas). Do ponto de vista simbólico, Thânatos apresenta o aspecto perecível e destruidor da vida (decomposição do corpo). É quem introduz as almas no Hades (mundo infernal). Em sua estreita ligação com todos os seres viventes da Terra, apresenta a função regenerativa, que o liga aos ritos de passagem, função que apresenta também quando está ligado ao seu irmão Hipnos.

O medo da morte faz parte do homem. Os gregos tinham uma relação de ódio com ela, pois morrer e ir para o Hades, transformava o homem em sombra. Uma vez lá, ele mergulhava no esquecimento. A poesia lírica permitiu ao poeta expressar de uma forma mais contundente a experiência da finitude humana em oposição à imortalidade dos deuses, como a poeta Safo: "É um mal morrer e os deuses bem o sabem; / Se assim não fora, eles próprios morreriam."

Muitos escritores, pensadores e filósofos, mas principalmente Maurice Blanchot, escreveram sobre a relação entre Morte e Literatura, a partir de obras de escritores como Kafka, Hölderlin e Rilke. Octávio Paz e Alfredo Bosi, em seus escritos sobre poesia também reservaram espaço para a análise da presença da morte na poesia. Os textos desses autores nos ajudaram profundamente na busca das possíveis respostas referentes ao tema deste trabalho: como se apresentam as mais variadas figuras da morte na poesia de Sophia Andresen.

\footnotetext{
${ }^{6}$ LACERDA, Alberto. “Sophia de Mello à cerca da sua poesia”. In: Távola redonda: Folhas de poesia, n. 07. Porto: 1950.

${ }^{7}$ Verificar Anexo -B.

${ }^{8}$ SAFO. "Poemas e fragmentos de Safo", in: Poesia e prosa. Tradução de Eugênio de Andrade. Lisboa: Ed. O Jornal, 1990, p.25.
} 
Um elemento poético presente na obra de Sophia Andresen é a preocupação com a despersonalização do eu lírico. Sophia Andresen refere-se a isso em "Arte Poética V", presente no livro Ilhas, de1989:

\begin{abstract}
Na minha infância, antes de saber ler, ouvi recitar e aprendi de cor um antigo poema tradicional português, chamado Nau Catrineta. Tive assim a sorte de começar pela tradição oral, a sorte de conhecer o poema antes de conhecer a literatura. Eu era de facto tão nova que nem sabia que os poemas eram escritos por pessoas, mas julgava que eram consubstanciais ao universo, que eram a respiração das coisas, o nome deste mundo dito por ele próprio. Pensava também que, se conseguisse ficar completamente imóvel e muda em certos lugares mágicos do jardim, eu conseguiria ouvir um desses poemas que o próprio ar continha em si. No fundo, toda a minha vida tentei escrever esse poema imanente. E aqueles momentos de silêncio no fundo do jardim ensinaram-me, muito tempo mais tarde, que não há poesia sem silêncio, sem que se tenha criado o vazio e a despersonalização. ${ }^{9}$
\end{abstract}

O "silêncio", o "vazio", são elementos importantes ao processo de despersonalização e estão presentes em boa parte dos poemas andresianos como premissa para a existência do próprio poema.

Alberto de Lacerda no texto "Sophia de Mello à cera da sua poesia", aponta a imaginação da poeta como um dos meios fundamentais a este processo:

Onde está a estranheza, a originalidade deste poeta? No aspecto novo por que reflecte emoções e pensamentos eternos da poesia, sobretudo da grande poesia; no poder quase mágico de plasmar as visões da sua imaginação inesgotável em versos de uma linguagem precisa, de um ritmo admirável, simultaneamente suspenso e calmo, cheio de silêncios [...]. ${ }^{10}$

Na revista Távola Redonda - Folhas de Poesia, de novembro de 1949, foram publicados alguns poemas inéditos de Sophia Andresen. Entre eles há um que fala do “mentir", do ser outro, da despersonalização do poeta em relação ao poema em si:

Juro que venho pra mentir

Tão profundamente

Que todos aqueles que um dia me mentiram

Talvez então encontrem a verdade.

\footnotetext{
${ }^{9}$ ANDRESEN, Sophia de Mello Breyner. Ilhas. Lisboa: Caminho, 2004, p. 76.

${ }^{10}$ LACERDA, Alberto de. "Sophia de Mello à cerca da sua poesia". In: Távola redonda: Folhas de Poesia, n. 07. Porto: $1950, \mathrm{~s} / \mathrm{p}$.
} 
Juro que nada tem sentido

No céu no mar no vento

Aprendi que os deuses morrem

Inutilmente. $^{11}$

O eu lírico ao iniciar o poema com o verso, "Juro que venho pra mentir", coloca em cheque todas as outras afirmações do poema, principalmente o verso que abre a segunda estrofe: "Juro que nada tem sentido". O poema é marcado pelo esvaziamento de qualquer verdade que se queira absoluta, pois até mesmo os deuses estão sob o domínio da finitude: “Aprendi que os deuses morrem / Inutilmente".

Conforme nos diz estes dois versos do poema, ironicamente, a mentira (dissimulação) é o caminho para se atingir a verdade: "Que todos aqueles que um dia me mentiram / Talvez então encontrem a verdade". O jurar de ter vindo "para mentir", feito pelo eu lírico, implica no deslocamento e na dissimulação do poeta. Essas relações entre mentira e verdade estão no mito das Musas, as filhas da Memória (Mnemosýne), descritas na Teogonia de Hesíodo:

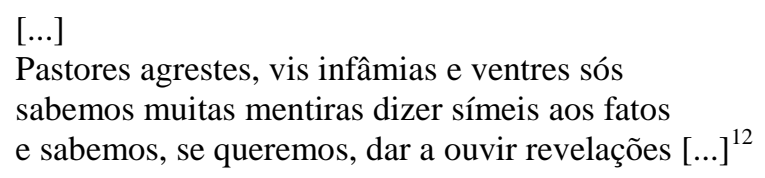

Ao dizer mentiras "símeis", as Musas ocultam a verdade e entram no campo das aparências, da semelhança. Esta é a ambigüidade da palavra poética, através da dissimulação desvelar o que antes estava oculto. Afirma Maurice Blanchot:

[...] não tendo o poema outro objeto senão ele próprio, a poesia, mais fortemente que em qualquer outra parte, ali é real e verdadeira, verdade que lhe dá o direito de dispor de todo o resto e primeiramente de tudo. ${ }^{13}$

\footnotetext{
11 ANDRESEN, Sophia de Mello Breyner. "Poemas inéditos". In: Távola redonda: Folhas de poesia, n. 07. Porto: $1950, \mathrm{~s} / \mathrm{p}$.

${ }^{12}$ HESÍODO, Teogonia. Tradução de JAA Torrano. São Paulo: Iluminuras, 1992, p. 107.

${ }^{13}$ BLANCHOT, Maurice. A parte do fogo. Tradução de Ana Maria Scherer. Rio de Janeiro: Rocco, 1997, p.115.
} 
Citando ainda Maurice Blanchot, em $O$ livro por vir, ele afirma que a representação pela ausência e o distanciamento presentes na arte é uma forma de poder:

[...] esse poder de representar pela ausência e de manifestar o distanciamento que está no centro da arte, poder que parece afastar as cosias para dizê-las, mantê-las à distância para que elas se esclareçam, poder de transformação, de tradução, em que é esse próprio afastamento (o espaço) que transforma e traduz, que torna visíveis nelas e se descobre então como fundo luminoso de invisibilidade e de irrealidade de onde vem e onde tudo acaba. ${ }^{14}$

A segunda estrofe traz um elemento muito presente na poesia de Sophia Andresen: a ausência. Todos, até mesmo os deuses

A partir deste doloroso aprendizado há a confirmação que tudo, inclusive os deuses, estão sob o domínio da finitude, pois até mesmo “[...] os deuses morrem / inutilmente". Perpassa, assim, em todo o poema uma visão negativa muito intensa diante do esvaziamento de qualquer afirmação que se quer absoluta.

O primeiro livro de Sophia Andresen, Poesia, é datado de 1944, ano em que ainda estava em curso a Segunda Guerra Mundial. Esse período foi extremamente conturbado, devido à estupidez humana e a uma voracidade da morte talvez nunca vista antes. Aprendemos a matar em grande escala e o horror, a loucura e o aspecto macabro que os homens externaram no concretizar destas mortes, fizeram que muitos chegassem a colocar em xeque a própria existência de Deus. O governo em Portugal estava sob a ditadura do Estado Novo, instituída por António de Oliveira Salazar ${ }^{15}$, e que durou de 1933 a 25 de Abril de 1974. De certa forma, os acontecimentos que vieram em decorrência desses movimentos bélicos e políticos ditatoriais também deixaram marcas na poesia de Sophia Andresen, ora

\footnotetext{
${ }^{14}$ Idem. O livro por vir. Tradução de Leyla Perrone-Moises. São Paulo: Martins Fontes. 2005, p.79.

${ }^{15}$ Sobre o contexto histórico desse período remetemos o leitor aos seguintes livros: SECCO, Lincoln Ferreira. A Revolução dos Cravos e a Crise do Império Colonial Português; MAXWELL, Kenneth. O Império Derrotado Revolução e Democracia em Portugal; CARVALHO, Joaquim Barradas de. O Obscurantismo Salazarista. Importantes revelações para a compreensão das relações entre a literatura portuguesa e a ditadura salazarista encontram-se em TCHEN, Adelaide. A Aventura Surrealista. Pensamos em ampliar as condições históricas, analisando inclusive, as mortes políticas referidas na obra da poeta em um momento mais à frente.
} 
descrevendo os horrores da guerra, como no poema "Os Aviões"16, do livro Geografia, de 1967, ora como relato e denúncia do sistema ditatorial, presentes no poema "Cidade dos Outros", também do mesmo livro.

Como foi dito no início deste texto, a obra de Sophia Andresen manteve um diálogo intenso com a cultura clássica, principalmente a mitologia grega, resultando em um corpus literário profundamente fecundo. Podemos encontrar na poesia andresiana todo um mundo fabuloso de imagens e símbolos míticos gregos que se alternam conforme a necessidade do poema. Porém, esse reencontro com o mundo clássico não se resume a um simples dejà vu ou a um simples "copiar de novo". Portanto, o estudo da presença das variadas imagens de Thânatos na poesia de Sophia Andresen parte da re-leitura que a poeta faz do universo clássico a partir das circunstâncias históricas do seu tempo e do seu olhar pessoal ${ }^{17}$.

Em vários poemas andresianos encontramos versos nos quais o sujeito ou o próprio poema apontam uma forte ligação com a morte: no poema "Signo", do livro Geografia, de 1967: "Meu signo é o da morte" "18; no poema "Sinto os mortos", do livro Poesia, de 1944: "E sei que trago em mim a minha morte"19 e em "Alexandre da Macedônia", de Mar Novo de 1947: "E o destino que em nós é caos e luto". ${ }^{20}$

A partir da leitura do poema "Signo", Maria João Borges diz que "O conhecimento da morte é a pedra em que assenta a identidade do sujeito." ${ }^{21}$ Este conhecimento de que o ser humano carrega a morte dentro de si, engendrando-a dia-a-dia, é uma dolorosa realidade a

\footnotetext{
${ }^{16}$ ANDRESEN, Sophia de Mello Breyner. Geografia. Lisboa: Caminho, 2004, p. 22.

${ }^{17}$ Esta dissertação não pretende julgar o quão grega Sophia Andresen foi ao exercer seu ofício poético. Apesar de a maioria dos críticos observar uma influência dessa cultura na sua obra, poucos foram aqueles que a demonstraram. Este trabalho visa dissertar e analisar os fundamentos míticos da cultura grega as leituras que deles são feitas, visto que não acreditamos que exista uma "cultura em si" pétrea e extraída de seu contexto receptivo.

18 ANDRESEN, Sophia de Mello Breyner. Geografia, Lisboa: Caminho, 2004, p. 40.

${ }^{19}$ Idem. Poesia. Lisboa: Caminho, 2005, p. 59.

${ }^{20}$ Idem. Mar novo. Lisboa: Caminho, 2003, p. 29.

${ }^{21}$ BORGES, Maria João. Em torno do conceito de poesia pura, Cinatti, Sophia e Eugênio de Andrade. Lisboa: Faculdade de Letras da Universidade de Lisboa, 1996, p.340.
} 
qual o eu lírico reenvia os seus questionamentos acerca da vida no mundo. O nosso destino como morte na poesia andresiana é uma constatação e fonte de indagação que impulsiona o gesto criador. No poema “O Sol, O Muro, O Mar” que está no livro Ilhas de 1989, o eu lírico expõe qual a missão do poeta: "Essa é a missão do poeta: trazer para a luz e para / o exterior o medo". ${ }^{22}$ A assimilação deste conhecimento que a cultura grega antiga deixou como herança está presente no poema “Os Gregos”, do livro Dual, de 1972: "Isto nos tornou atentos a todas as formas que a Luz do Sol conhece / E também à treva interior por quem somos habitados". ${ }^{23}$

Esta dissertação divide-se em três capítulos - Thânatos: o Tempo e a Memória, Thânatos e a Noite, Thânatos, do Minotauro às Fúrias - que enfocam as relações entre as mais variadas imagens do mito de Thânatos e a poesia de Sophia de Mello Breyner Andresen.

No primeiro capítulo, analisaremos as figuras de Tempo. Como se estabelecem as relações entre morte e tempo? Mauro Maldonato afirma que, "a morte é a forma pela qual identificamos e compreendemos o tempo" (Subervsão do Ser), ${ }^{24}$ A tomada de consciência pelo ser humano de um fluxo de tempo que não pára e a sua fixação em um determinado tempo e espaço, em que seja possível olhar para trás, são algumas marcas distintivas da poesia lírica grega que também estão presentes na poesia andresiana.

Ainda neste capítulo estudaremos as implicações que se estabelecem entre a deusa da Memória (Mnemosýne) e a Thânatos. No decorrer da fluidez do tempo, é a memória que armazena e possibilita as lembranças de toda uma vida, nossas lembranças afetivas, nossos traumas. Quais são as relações que se estabelecem entre desvelamento (aletheia) e esquecimento (lethe)?

\footnotetext{
22 ANDRESEN, Sophia de Mello Breyner, Ilhas, Lisboa, Caminho, 2004, p. 45.

${ }^{23}$ Idem. Dual. Lisboa, Caminho, 2004, p. 65.

${ }^{24}$ MALDONTATO, Mauro. A Subversão do Ser. Tradução de Luciano Loprete e Roberta Barni. São Paulo: Peirópolis, 2001, 148
} 
Entre os poemas escolhidos para formar o corpus de poemas a serem analisados neste capítulo temos: "Cada dia é mais evidente que partimos" (Coral de 1950), "O Minotauro" (O Nome das Coisas de 1977), "Intacta Memória" (No Tempo Divido de 1954), "De um Amor Morto" e "Carta A Maria Carvalhal Avito" (Ilhas de 1989).

O capítulo segundo tem como meta de estudo uma investigação sobre as relações que podem ser traçadas entre o mito de Thânatos e o mito da Noite.

Na mitologia grega Thânatos é filho da Noite, irmão de Hipnos. Na Grécia, todos os sacrifícios e libações destinadas aos mortos eram feitas no período da noite, o período noturno sempre foi fecundo em mistérios e elementos fantasmagóricos.

O ambiente noturno, nos poemas andresianos, geralmente é marcado por certa melancolia, espanto. Também é espaço mágico, sombrio e mundo fantasmagórico onde o contato com o outro pode resultar medo e tensão, como por exemplo, no poema "Noites das Coisas", do livro Poesia de 1944:

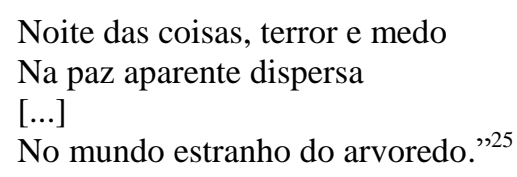

O espaço noturno terá na figura do jardim um dos seus elementos preferidos. Muitas vezes relacionado com a infância, toda a vida abundante que ele cerca, de flores, árvores, lagos, fontes, faz com que ele se aproxime da imagem do Paraíso, como por exemplo, o poema "Jardim Perdido", do livro Dia do Mar, de 1947:

Jardim perdido, a grande maravilha

Pela qual eternamente em mim

A tua face se ergue e brilha

Foi esse teu poder de não ter fim,

Nem tempo, nem lugar e não ter nome $[\ldots]^{26}$

\footnotetext{
${ }^{25}$ ANDRESEN, Sophia de Mello Breyner, Poesia. Lisboa: Caminho, 2005, p. 21.

${ }^{26}$ Idem. Dia do mar. Lisboa: Caminho, 2003, p. 78.
} 
A imagem totalizadora da noite contém aspectos mágicos, associada a um espaço ilimitado que possibilita a evasão do eu lírico, que busca a liberdade. Segundo Júlia Kristeva, a construção destes ambientes paradisíacos, livres de quaisquer limites de tempo e espaço, está relacionada com a morte, ou melhor, com a vontade de não estar vulnerável a ela:

\begin{abstract}
Em lugar da morte, e para que não morrer da morte do outro, eu produzo - ou pelo menos penso fazê-lo - um artifício, um ideal, um "além" que minha psique produz para se colocar fora dela: êx-tase. Belo por poder substituir todos os valores psíquicos perecíveis. ${ }^{27}$
\end{abstract}

Para o segundo capítulo foram selecionados alguns poemas nos quais ocorre a presença da imagem da Noite. Entre os poemas selecionados temos: "O Jardim e a Noite" (Poesia de 1944), “Noite” (Poesia de 1944), “Os Pássaros” (Coral de 1950). Também será analisado o poema "Os mortos de Hecate", do livro Dia do mar, de 1947, no qual é resgatado o mito da deusa Hecate, ligada ao período noturno, a Lua. Está associada ao mundo dos mortos, como o próprio título do poema diz.

No terceiro e último capítulo, depois de passar pelo tempo, pela memória, verificaremos outro possível aspecto da poesia de Sophia de Mello Breyner Andresen, assentado na relação estabelecida entre Thânatos e as Fúrias. Surgirão no espaço do poema monstros como o Minotauro, o polvo e o touro representando as forças da violência humana. As Fúrias, divindades mitológicas, representavam a sede de vingança. Essas deusas violentas aparecem em vários poemas, como em "Ménades", do livro Musas, de 1994, no qual o mito dessas vingadoras mescla-se com o mito das seguidoras de Dioniso.

Eis alguns poemas a serem estudados no capítulo terceiro: "Elsinore" (Ilhas de1989), “As Sibilas" (Coral de1950), "Electra" (Geografia de1967), "Medeia" (Dia do Mar de 1947). A seleção de poemas visa permitir o estudo de questões que se instauram a partir do momento

\footnotetext{
${ }^{27}$ KRISTEVA, Júlia. Sol negro: depressão e melancolia. Trad. Carlota Gomes. Rio de Janeiro: Rocco, 1997, p.96.
} 
que o eu lírico assume a voz ou cede espaço para essas personagens marcantes, transgressoras e todas têm em comum uma relação muito forte e destruidora com a morte.

Neste capítulo verificaremos quais os sentimentos intensos surgem, como a fúria, e como eles apresentam-se. Quais são os pontos que podemos levantar em decorrência da presença de sentimentos intensos como os que surgem no poema "Marinheiros sem mar", do livro Mar novo? A morte de uma forma ou de outra está sempre presente na nossa civilização, cabe-nos investigar quais os sentidos desta presença. Quais as indagações que esta suscita através dos poemas andresianos? 


\section{THÂNATOS: O TEMPO E A MEMÓRIA}

Thânatos, na mitologia grega, não constitui propriamente um mito, mas está presente das mais variadas formas em outros, como por exemplo, no mito de Chronos (Tempo) e de Mnemosýne (Memória). Este capítulo visa estudar como se estabelecem as relações entre essas figuras e a poesia de Sophia Andresen.

A imagem do tempo, na poesia andresiana, é tão importante que deu nome ao livro No tempo dividido, de 1954, e aparece de forma marcante em quase toda a sua obra.

A percepção da passagem do tempo, por parte do eu lírico resulta, muitas vezes, em uma experiência melancólica, dolorosa. Assim, como aponta Eduardo Prado Coelho, no ensaio "Sophia, a lírica a lógica", o tempo, sentido como um inimigo, pode apresentar a figura de um monstro, como por exemplo, o Minotauro ${ }^{28}$. Essa metáfora do tempo como um monstro insaciável está presente em vários poemas andresianos, por exemplo, no poema “O Minotauro", do livro O nome das coisas, de 1977:

Assim o Minotauro longo tempo latente
De repente salta sobre a nossa vida
Com veemência vital de monstro insaciado

O tempo, aqui, é retratado como um monstro traiçoeiro, vigoroso e insaciável, que traz a nossa morte. Engendra-a dia após dia no tempo de "nossa vida". Nunca sabemos quando nosso tempo vai terminar. Esse desconhecimento é, para além de muitos outros sentimentos que estudaremos neste trabalho, motivo de angústia e, por vezes, de indignação. Sempre a nos pegar de surpresa, o Minotauro-tempo devora nossa vida, “com veemência vital de monstro insaciado".

\footnotetext{
${ }^{28}$ COELHO, Eduardo Prado. “Sophia, a lírica e a lógica”. In: Colóquio Letras, n. 57. Lisboa, 1980, p. 25.

${ }^{29}$ ANDRESEN, Sophia de Mello Breyner. O nome das coisas. Lisboa: Caminho, 2004, p. 51.
} 
Cronos na mitologia grega era filho de Urano (o Céu) e de Gaia (a Terra). Ajudou a mãe a vingar-se do pai, cortando-lhe os testículos e logo em seguida tomou o trono. Cronos casou-se com Rea, sua irmã. Descobriu que seria destronado por um de seus filhos, e numa tentativa de evitar que isto acontecesse passou a devorá-los. Indignada, logo que Zeus nasceu, Rea o enviou para a ilha de Creta em segredo. Envolveu uma pedra em panos como se este fosse Zeus e entregou-o ao marido, que o devorou. Zeus cresceu escondido na ilha. Quando ficou adulto, obrigou o pai a vomitar todos os irmãos. Logo em seguida, juntamente com seus irmãos, entrou em guerra contra o pai, da qual Zeus saiu vitorioso (este conflito é conhecido como Titanomaquia) ${ }^{30}$. Assim sendo, Cronos ao mesmo tempo em que engendra a vida, também a devora, ele "simboliza a fome devoradora da vida, o desejo insaciável [...]" e com ele inicia "um sentimento de uma duração" que se esgota ${ }^{31}$. Segundo Jean-Pierre Varnant:

[...] Chrónos é divinizado e situado como a própria origem do cosmo. [...] Ser vivo e noção abstrata, Chrónos representa, pois, no início das coisas, o papel de um princípio de unidade que transcende todos os contrários. [...] É preciso não se equivocar sobre o alcance dessa divinização de Chrónos e sobre a nova importância dada ao tempo nesse tipo de teogonia. O que é sacralizado é o tempo que não envelhece, o tempo imortal e imperecível, cantado nos poemas órficos sob o nome de Chrónos agéraos. [...] Sob sua forma divina, Chrónos aparece, na qualidade princípio de unidade e de permanência, como a negação radical do tempo humano, cuja qualidade afetiva é, ao contrário, a de uma força de instabilidade e de destruição presidindo, como Parão o proclamava, ao esquecimento e à morte. ${ }^{32}$

Segundo Mauro Maldonato, “a morte é a forma pela qual identificamos e compreendemos o tempo. ${ }^{, 33}$ Partindo desse faz-se pertinente ressaltar o mesmo aspecto, apontado por Eduardo Prado Coelho na poesia de Sophia Andresen:

Daí que haja em Sophia uma espécie de integração da morte convertida em mero lugar de passagem no percurso irreprimível da vida. A morte é preparada em cada instante da vida. Na medida em que o visível se debruça sempre para o lado de lá do

\footnotetext{
${ }^{30}$ KURY, Mário da Gama. Dicionário de mitologia grega e romana. Rio de Janeiro: Jorge Zahar Editor, 1999, p. $96-97$.

${ }^{31}$ CHEVALIER, Jean; GHEEBRANT, Alain. Dicionário de símbolos. Tradução de Vera da Costa e Silva. Rio de Janeiro: José Olympio, 2008, p. 307.

${ }^{32}$ VERNANT, Jean-Pierre. Mito e pensamento entre os gregos. Tradução de Haiganuch Sarian. São Paulo: Paz e Terra. 2002, p. 155-156.

${ }^{33}$ MALDONATO, Mauro. A subversão do ser. Tradução de Luciano Loprete e Roberta Barni. São Paulo: Peirópolis, 2001, p. 148.
} 
invisível, a morte aflora em cada instante de intensificação do real, é um tecer incessante que se entrelaça em nós. ${ }^{34}$

Podemos verificar tais elementos no pequeno poema abaixo, presente no livro Coral, de 1950:

Cada dia é mais evidente que partimos,

Sem nenhum possível regresso no que fomos,

Cada dia as horas se despem mais do alimento:

Não há saudade nem terror que baste. ${ }^{35}$

A percepção da passagem do tempo e a certeza de que não há como cessar o seu movimento contínuo estão expressas no primeiro verso do poema: "Cada dia é mais evidente que partimos”. O eu lírico fala de um tempo que não é circular, mas sim linear, pois este não permite a possibilidade de "regresso no que fomos". O fluir do tempo é marcado através da passagem de "cada dia", das "horas" que "se despem", que se afastam "mais do alimento", e consequentemente, da vida. Toda essa interiorização do processo do tempo pelo eu lírico implica dois sentimentos profundos: "saudade" de quem já é ausência e "terror" diante da sua voracidade, já que não há nada que o sacie. A mobilidade sequencial de cada evento de modo incessante e absoluto registrada pelo eu lírico contém, portanto, a clássica ideia contida no mito original de Cronos, do tempo como um agente também do fim.

É dentro dessa visão que Maria João Borges afirma que, na poesia de Sophia Andresen, "morte e tempo identificam-se, confundem-se os seus rostos, [...] pois existir é perecer" ${ }^{36}$ e, visto que:

Por detrás da morte opera o tempo, ele trá-la consigo, é ele o agente do mal e a substância de que se alimentam os nossos dias. [...] a morte surge como o mal

\footnotetext{
${ }^{34}$ COELHO, Eduardo Prado. "Sophia, a lírica e a lógica". In: Colóquio Letras, n. 57. Lisboa, 1980, p. 27.

${ }^{35}$ ANDRESEN, Sophia de Mello Breyner. Coral, Lisboa, Caminho, 2005, p. 79.

${ }^{36}$ BORGES, Maria João. Em torno do conceito de poesia pura, Cinatti, Sophia e Eugênio de Andrade. Lisboa: Faculdade de Letras da Universidade de Lisboa, 1996, p. 342.
} 
absoluto, cuja consciência se vai dolorosamente ampliando e intensificando, até ao intolerável.[...] ${ }^{37}$.

A aprendizagem e a interiorização do ensinamento desse tempo que devora nossos dias, horas e momentos implicam sentimentos melancólicos, angustiantes. Gera-se uma lamentação não somente pelo que podemos ter de perda no porvir, mas como também pelo que deixamos de realizar e conquistar. Esses sentimentos estão inscritos em vários poemas, como por exemplo, em “Às Vezes”, do livro Poesia, de 1944:

Às vezes julgo ver nos meus olhos

A promessa de outros seres

Que eu podia ter sido,

Se a vida tivesse sido outra.

Mas dessa fabulosa descoberta

Só me vem o terror e a mágoa

De me sentir sem forma, vaga e incerta

Como a água. ${ }^{38}$

O poema é composto de duas estrofes de quatro versos cada uma. Não há uma regularidade na métrica, optando-se pelos versos livres. Com relação ao uso intenso dos versos que não seguem uma "ordenação uniforme" e a oralidade existente na poesia andresiana, Joaquim Manuel Magalhães aponta certos fatores que são pertinentes tanto para o poema acima, quanto para outros que serão analisados no decorrer deste trabalho:

[...] maioritariamente próximo da presença de uma regularidade - ou em redor das redondilhas ou em redor do decassílabo -, mas quebrando sempre uma possível melopeia pela oscilação de uma ou outra sílaba para mais ou para menos; pela interligação numa espécie de socalcos rítmicos causados pela não unidimensionalidade do verso e pela não desordenação sintáctica. Por aí a oralidade demanda a clareza afirmativa e as síncopes que criam suspensão no processamento das significações. E tudo isto sem nunca se produzirem rupturas através de infracções aos códigos de partilha habituais. ${ }^{39}$

\footnotetext{
${ }^{37}$ BORGES, Maria João. Em torno do conceito de poesia pura, Cinatti, Sophia e Eugênio de Andrade. Lisboa: Faculdade de Letras da Universidade de Lisboa, p. 342.

${ }^{38}$ ANDRESEN, Sophia de Mello Breyner. Poesia. Lisboa: Caminho, 2005, p. 20.

${ }^{39}$ MAGALHÃES, Joaquim Manuel. Rima pobre. Lisboa: Presença, 1999, p. 50.
} 
Ao iniciar o poema com a expressão "às vezes", o eu lírico deixa claro que essa situação pela qual passa ocorre com incerta regularidade, mas que não é algo novo e pontual. Temos, portanto, um eu lírico que, em algum momento, pára e vê-se diante da impossibilidade de qualquer alteração do presente em relação ao passado. O confrontar-se com essa terrível realidade lhe dá a certeza de que ele está sujeito à mobilidade irreversível do tempo, e que nada pode alterar o passado em detrimento do presente, conforme percebemos destes versos da primeira estrofe:

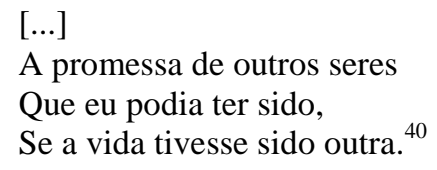

O uso da conjunção "se" e do verbo no modo subjuntivo, "tivesse", reafirma o aspecto apenas hipotético da divagação perante a impossibilidade de se alterar o passado. Esta "fabulosa descoberta" provoca sentimentos de "terror" e de "mágoa", visto que, mergulhado na abstração que a divagação momentânea lhe impõe, o sujeito declara que se sente "sem forma, vaga e incerta / como a água". Eis o doloroso conhecimento por parte do sujeito diante da intensidade da experiência do real no confronto com a subjetividade do tempo interior: a vida (tempo) manifesta-se tal como ela é.

No poema "Se" do livro Poesia, de 1944, encontramos o mesmo tema da constatação dolorosa do fluir incessante do tempo por parte do eu lírico:

\footnotetext{
Se tanto me dói que as coisas passem É porque cada instante em mim foi vivo Na luta por um bem definitivo Em que as coisas de amor se eternizassem. ${ }^{41}$
}

O uso da conjunção “se", no início do primeiro verso, exprime uma circunstância que condiciona tudo o que é relatado nos versos seguintes. A tensão nasce da impossibilidade do

\footnotetext{
${ }^{40}$ ANDRESEN, Sophia de Mello Breyner. Poesia. Lisboa: Caminho, 2005, p. 20.

${ }^{41}$ Ibidem, p. 32.
} 
eu lírico em perpetuar o instante, de onde advém a dor intensa que o sujeito diz sentir, visto que tem a conscientização de "que as coisas" passam. Como explica Mauro Maldonato, o tempo é uma linguagem de separação, pois quando olhamos para trás, para a nossa existência, nossa vida, ela já não nos pertence mais ${ }^{42}$.

A consciência da finitude torna o tempo objeto de preocupação na obra andresiana. Todas as vezes que a poesia andresiana, tenta transcender o jugo que o tempo impõe, surgem sentimentos de angústia e de melancolia, como podemos verificar nos versos do poema "Céu, Terra, Eternidade" presente no livro Poesia, de 1944:

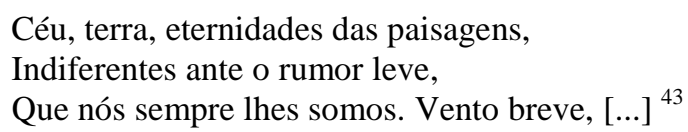

A onipresença das imagens "Céu, terra", contraposta à finitude humana, faz com que o tempo assuma o aspecto de uma força extremamente negativa e melancólica. Para Jean-Pierre Vernant, a tomada de consciência de "um tempo humano esvaindo-se sem retorno ao longo de uma linha irreversível”44, surge com a poesia lírica. Essa mesma percepção da brevidade das horas pode ser encontrada nestes versos do poema "Dia de Hoje", do livro Dia do Mar, de 1947:

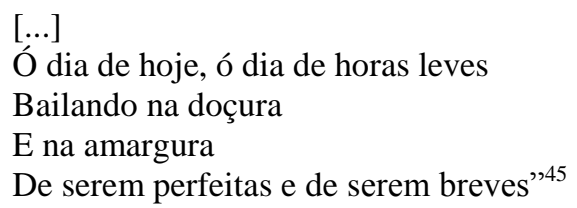

No poema, há uma tentativa de eufemismo na caracterização dessa força avassaladora. O correr do tempo é descrito como "ó dia de horas leves", quando o eu lírico utiliza-se da

\footnotetext{
${ }^{42}$ MALDONATO, Mauro. A subversão do ser. Tradução de Luciano Loprete e Roberta Barni. São Paulo: Peiropólis, 2001, p. 139

${ }^{43}$ ANDRESEN, Sophia de Mello Breyner. Poesia. Lisboa: Caminho, 2005, p. 47.

${ }^{44}$ VERNANT, Jean-Pierre. Mito e pensamento entre os gregos. Tradução de Haiganuch Sarian. São Paulo: Paz e Terra, 2002, p. 158.

45 ANDRESEN, Sophia de Mello Breyner. Dia do mar. Lisboa: Caminho, 2003, p. 18.
} 
metáfora para estabelecer igualdade entre o movimento das horas com os movimentos graciosos e leves de um bailar. Porém, esse clima rompe-se ao introduzir-se um efeito de tensão e de dramaticidade da situação, incorporado ao poema através de algumas palavras que se opõem entre si: "doçura" / "amargura"; "perfeitas" / "breves".

Segundo Paul Diel, Cronos é um deus titã (primeira geração dos deuses). Representa as forças brutas e selvagens da terra, o que esclarece o ato de engolir os próprios filhos ${ }^{46}$. Ele nos impõe a todos a mesma lei: a vida acabará por ser consumida em um envelhecimento contínuo: criança, adulto, velho e cadáver. Ele nos ensina que nada é imutável, como podemos verificar neste poema do período bizantino de autor anônimo:

\footnotetext{
Silente e encanecido, o Tempo avança, mas roubando Em seu avanço, as vozes dos homens loquazes. Ele, que ninguém vê, tira de vista o que se via E coloca o que não se via em plena vista. Que indefinido o fim da vida humana, dia a dia Mais perto, sempre mais perto, da escuridão! ${ }^{47}$
}

O poema apresenta um dos elementos que caracterizavam o mito de Cronos, na Idade Antiga, a invisibilidade: "Ele, que ninguém vê, tira de vista o que se via". O tempo tira o vivo do universo luminoso e o conduz para o mundo da noite, Hades. A morte é o espaço do silencio, roubando “[...] as vozes dos homens loquazes”. Portanto, o ser humano está sempre "Mais perto, sempre mais perto da escuridão".

A imagem da morte na poesia do poeta Rainer Maria Rilke é um dos aspectos que influenciou muito a obra de andresiana, como por exemplo, o poema "Final":

\footnotetext{
${ }^{46}$ DIEL, Paul. O simbolismo na mitologia grega. Tradução de Roberto Cacuro e Marcos Martinho dos Santos. São Paulo: Attar, 1991, p. 34.

${ }^{47}$ Poemas da antologia grega ou palatina. Organização e tradução de José Paulo Paes. São Paulo: Companhia das Letras, 2001, p.101.
} 


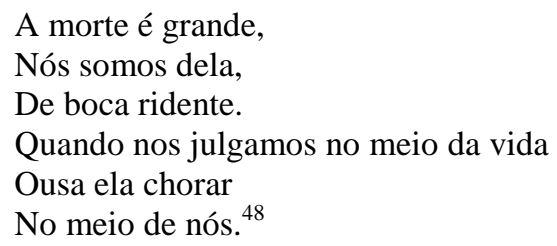

Há certa idealização por parte do eu lírico em relação à morte, ela "é grande”. Estamos completamente sobre o seu domínio: "Nós somos dela". Seu mistério faz com que estejamos completamente alheios a ela, o que é motivo de angústia para o eu lírico. Vivemos felizes como se fossemos seres imortais. Então, traicoeiramente ela age:

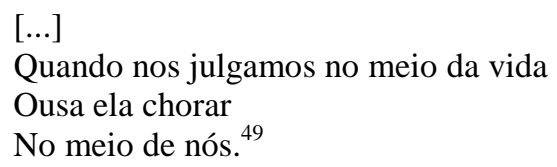

No poema "Morte", do livro Dual, de 1972, o eu lírico expressa também sua angústia diante do poder da morte:

\footnotetext{
Que triângulo ou círculo poderá cercar-te

Para que te detenhas demorada e minha

Para que não desças toda pela escada ${ }^{50}$
}

O sujeito tem a plena consciência de seu destino finito e particular no uso do pronome “minha”. Novamente, a preocupação e a intraquilidade surgem diante da impossibilidade de controlar o caminhar do tempo e o retardamento da morte o máximo possível: “detenhas demora" e "não desças toda pela escada". Assim, temos um diálogo com o tu no qual a vontade de viver é intensificada. No poema "Brisa", do livro Mar novo, de 1958, o eu lírico apresenta a mesma inquietação e pergunta: “[...] Quem poderá deter / O instante que não pára de morrer?"51

\footnotetext{
${ }^{48}$ RILKE, Rainer Maria. Poemas as elegias de Duíno e sonetos a Orfeu. Tradução de Paulo Quintana. Porto: O Oiro do Dia, 1983, p.83.

${ }^{49}$ Ibidem, p. 83.

${ }^{50}$ ANDRESEN, Sophia de Mello Breyner. Dual. Lisboa: Caminho, 2004, p. 11.

${ }^{51}$ Idem. Mar novo. Lisboa: Caminho, 2003, p. 63.
} 
Sobre a invisibilidade e desconhecimento da morte em alguns poemas de Sophia Andresen, Eduardo Prado Coelho diz que há "uma espécie de integração da morte” com o tempo, pois esta é:

[...] convertida em mero lugar de passagem no percurso irreprimível da vida. A morte é preparada em cada instante da vida. Na medida em que o visível se debruça sempre para o lado de lá do invisível, a morte aflora em cada instante de intensificação do real, é um tecer incessante que se entrelaça em nós. ${ }^{52}$

O espaço poético, muitas vezes, tem a função de acolher e de proteger contra a ação do tempo, como em "No Poema”, presente em Livro Sexto, de 1962:

\author{
Transferir o quadro o muro a brisa \\ A flor o copo o brilho da madeira \\ E a fria e virgem liquidez da água \\ Para o mundo do poema limpo e rigoroso \\ Preservar de decadência morte e ruína \\ O instante real de aparição e de surpresa \\ Guardar num mundo claro \\ O gesto claro da mão tocando a mesa ${ }^{53}$
}

Quase todas as palavras que compõem os quatro versos da primeira estrofe são substantivos ou adjetivos, como por exemplo, "quadro", “muro", "limpo", “fria”. Há apenas a presença de um verbo, "transferir", que abre o primeiro verso. Ao lermos a primeira parte do poema, fica nítida qual a intenção, o desejo que move o eu lírico: trazer para o "mundo do poema limpo e rigoroso" as coisas e salvaguardá-las da "decadência morte e ruína".

O espaço do poema pode tornar-se um espaço mágico, em alguns poemas, onde a sua duração é eterna, não podendo ser dissolvido ou dividido: “Onde o tempo não é dissolvido

\footnotetext{
${ }_{52}^{52}$ COELHO, Eduardo Prado. "Sophia, a lírica e a lógica". In: Colóquio/ Letras, n. 57. Lisboa, 1980, p. 27.

${ }^{53}$ ANDRESEN, Sophia de Mello Breyner. Livro sexto. Lisboa: Caminho, 2003, p. 32.
} 
mas dura"54 (O Búzio de Cós, de 1997). Maria João Borges lembra que, "ao tempo não resiste o esplendor do real, o tempo da revelação é também tempo de morte."55

Mauro Maldonato, ao analisar a questão do tempo na sociedade contemporânea, coloca que o instante na sua "absoluta, paradoxal exterioridade, é a medida mais íntima do fim do tempo como experiência." ${ }^{56}$ De certa forma, é este o movimento que encontramos no poema: o eu lírico transporta para o interior do poema a exterioridade do instante e tenta preservá-la do tempo. Mas, citando ainda Mauro Maldonato, ele nos lembra que:

[...] o instante está sujeito ao tempo (e juntamente sujeito no tempo), porém não é do tempo. Sua encenação - o teatro que denominamos "presente" - é um movimento rápido, efêmero, frágil. Nessa cena, o instante, o ato livre do instante, se tenciona sobreviver, tem de enfrentar o devir. O devir tem por campo de ação a liberdade. Quando esta pretende exercitar-se no passado ou no presente torna-se escravidão. ${ }^{57}$

Nos dois últimos versos do poema, "Guardar num mundo claro / O gesto claro da mão tocando a mesa", o adjetivo "claro" traça um elo entre o "mundo" e o fazer poético, representado pelo "gesto" da "mão tocando a mesa". Com relação a estreita ligação entre o "instante real" e a palavra, entre o nome e o espaço do poema, que ocorre principalmente na primeira estrofe, podemos citar uma fala de Alfredo Bosi, que está presente no livro $O$ Ser e o Tempo da Poesia, de 1977:

A poesia dá voz à existência simultânea, aos tempos do Tempo, que ela invoca,
evoca, provoca. [...] Logo, há entre o poeta e o campo da experiência não só a
mediação imagística como também as várias mediações do discurso: o tempo, o
modo, a pessoa, o aspecto, faces todas que a predicação verbal configura. ${ }^{58}$

\footnotetext{
${ }^{54}$ ANDRESEN, Sophia de Mello Breyner. O búzio de cós. Lisboa: Caminho, 1999, p. 27.

${ }^{55}$ BORGES, Maria João. Em torno do conceito de poesia pura, Cinatti, Sophia e Eugênio de Andrade. Lisboa: Faculdade de Letras da Universidade de Lisboa, 1996, p. 342.

${ }^{56}$ MALDONATO, Mauro. A subversão do ser. Tradução de Luciano Loprete e Roberta Barni. São Paulo: Peirópolis, 2001, p.114.

${ }^{57}$ Ibidem, p. 114.

${ }^{58}$ BOSI, Alfredo, O ser o tempo da poesia. São Paulo: Cultrix, 1993, pp. 121-146.
} 
Eduardo Prado Coelho lembra que na poesia andresiana há "uma forma de morte que é inassimilável", a qual está diretamente relacionada com o passar do tempo, que é "a degradação":

Mas essa forma de ir morrendo que é a degradação instaura um processo de presença não-presença que é intolerável [...]. A morte perfeita é a passagem do tempo comum para o tempo fora do tempo. A morte por degradação é a passagem do tempo da vida para o inferno do tempo: o tempo dentro do tempo, o tempo da história. ${ }^{59}$

O poema "Meditação do Duque de Gandia sobre a morte de Isabel de Portugal", do livro Mar novo, de 1958, contém o sentimento de horror que a degradação física pelo tempo e a morte causam:

\author{
Nunca mais \\ A tua face será pura limpa e viva \\ Nem o teu andar como onda fugitiva \\ Se poderá nos passos do tempo tecer. \\ E nunca mais darei ao tempo a minha vida.
}

Nunca mais servirei senhor que possa morrer.

A luz da tarde mostra-me os destroços

Do teu ser. Em breve a podridão

Beberá os teus olhos e os teus ossos

Tomando a tua mão na sua mão.

Nunca mais amarei quem não possa viver

Sempre,

Porque eu amei como se fossem eternos

A glória, a luz e o brilho do teu ser,

Amei-te em verdade e transparência

E nem sequer me resta a tua ausência,

És um rosto de nojo e negação

E eu fecho os olhos para não te ver.

Nunca mais servirei senhor que possa morrer. ${ }^{60}$

O poema não trata do lado glorioso da morte como meio para unidade entre todos os seres, nem meio para a imortalidade. Ele fala do lado mais obscuro e sombrio da morte material: o horror da decomposição do corpo.

\footnotetext{
${ }^{59}$ COELHO, Eduardo Prado. "Sophia, a lírica a lógica”. In: Colóquio Letras. Lisboa, n. 57, 1980, p. 28.

${ }^{60}$ ANDRESEN, Sophia de Mello Breyner. Mar novo. Lisboa: Caminho, 2003, p. 28.
} 
Para discorrer no poema sobre o pavor da morte física, a poeta Sophia Andresen aproveitou como mote a lenda em torno da Imperatriz Dona Isabel de Portugal. Ela era filha de D. Manuel I, rei de Portugal, e de Maria de Aragão, infanta de Espanha. Casou-se com Carlos V, Imperador do Sacro Império. Ficou conhecida por sua educação e pela sua extrema beleza, tendo sido retratada por Ticiano. Morreu em decorrência de complicações após o parto. D. Carlos encarregou o duque de Gandia a conduzir o corpo até Granada, onde se encontrava. Ao abrirem o caixão para verificação do cadáver, a decomposição encontrava-se avançada, tendo destruído totalmente a formosura da mulher mais bela da época. Perante a hedionda visão do cadáver decomposto, o duque de Gandia, que nutria amor platônico pela imperatriz, jurou nunca mais servir a nenhum ser mortal.

O poema inicia-se com uma expressão forte: "Nunca mais", promessa que implica também a morte de algo que não se repetirá jamais. Portanto, o verso inicia com a vontade de uma privação.

Em todas as estrofes há um confronto entre o belo e o horroroso. O conceito de "belo" era muito forte no mundo grego antigo, onde representava a harmonia e o equilíbrio da forma. No entanto, sua presença, no poema, é secundária, servindo apenas para ressaltar o horror. Ao se falar da beleza intensa de D. Isabel, o eu lírico, na realidade, fala de tudo que é perecível, transitório, momentâneo e finito; está falando de um mundo que está sob o domínio impiedoso do tempo. No confronto com a transitoriedade deste, nada sobrevive, nem mesmo os encantos da beleza: "Nem o teu andar como onda fugitiva / Se poderá nos passos do tempo tecer."

A partir desta constatação, o sujeito lírico relata todo o horror que experimentou em relação à destruição que a morte traz. Há palavras pontuais que retratam essa experiência 
terrível: "destroços", "podridão", "nojo". A luz revela a verdade sobre a morte (escuridão) ao eu lírico: “A luz da tarde mostra-me os destroços / De teu ser [...]”:

Morte é metamorfose, é transformação:

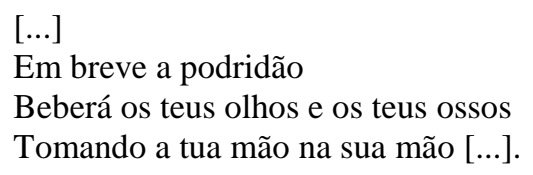

O tempo que não poupa o belo, a tudo devora com uma fome atroz. Talvez neste fato resida a maior consternação e repulsa por parte do sujeito lírico. A degradação do corpo é a face mais monstruosa da morte. Talvez, por isso, os gregos antigos, que tiveram uma interação muito intensa com o morrer, possuíam vários mitos para representar o horror da decomposição: as Górgonas, as Fúrias, a Medusa, as Keres entre outros. Segundo Jean-Pierre Vernant:

Gorgó é uma força que o homem não poder abordar sem cair vítima de seu olhar. [...] Exposto ao olhar de Gorgó, o homem defronta-se com as forças do Além na sua alteridade mais radical, a da morte, da noite, do nada. [...] Na face de Gorgó, o bestial sobrepõe-se ao humano. ${ }^{61}$

O aniquilamento pela morte é algo tão dramático e terrível, que nem mesmo os deuses o encaravam. Um bom exemplo é Hipólito, filho de Teseu, fiel seguidor da deusa Ártemis. Perto de morrer, chama por ela, mas esta o abandona, pois até mesmo aos deuses a morte era uma visão medonha.

\footnotetext{
${ }^{61}$ VIDAL-NAQUET,Pierre, Jean_Pierre VERNANT. Mito e tragédia na Grécia antiga. Tradução de Anna Lia A. de Almeida Prado. São Paulo: Perspectiva, 2008, p. 166.
} 
Ao analisar os ritos fúnebres existentes em todas as partes do mundo, Ernst Cassirer diz que eles tendem para o mesmo ponto: "o medo da morte". E deduz que "a primeira reação do homem para com o cadáver deve ter sido de abandoná-lo à sua sina e fugir aterrorizado" ${ }^{\circ 2}$.

É em torno do virar os olhos à morte que gravitam as outras ações da quarta estrofe do poema "Meditação do Duque de Gandia sobre a morte de Isabel de Portugal":

$[\ldots]$

E nem sequer me resta a tua ausência

És rosto de nojo e negação

E eu fecho os olhos para não te ver $[\ldots]^{63}$

Porém, antes houve o olhar, o conhecer e o reconhecer da cena macabra, que a presença do cadáver ensina: "És rosto de nojo e negação”. A figura medonha e macabra que a morte impõe à sua amada é mais forte e destrói a imagem que foi construída da beleza física e que ele amava. Ao fazê-lo, o assombro assume o espaço vago deixado pela beleza que já não existe mais: "E nem sequer me resta a tua ausência / És um rosto de nojo e negação".

No livro Sol negro - depressão e melancolia ${ }^{64}$, Júlia Kristeva fala do choque que provocou o quadro Cristo Morto, do pintor Hans Holbein, no príncipe Myschkine, descrito no livro $O$ idiota, de Dostoievski. Assim, como no poema andresiano, o assombro diante da morte física é descrito em cores sóbrias e limpas. E a visão crua da morte faz com que o príncipe sinta, ao mesmo tempo, angústia, medo, horror e fascínio. E isto faz com ele não consiga se mover. Relata o príncipe:

Sei que, desde os primeiros séculos, a Igreja cristã professou que os sofrimentos do Cristo não foram simbólicos, mas reais, e que, na Cruz, seu corpo foi submetido, sem nenhuma restrição, às leis da natureza. $\mathrm{O}$ quadro representava portanto um rosto terrivelmente desfigurado pelos golpes, intumescido, coberto por atrozes e sangrentas equimoses, com os olhos abertos e marcados pelo brilho vítreo da morte,

\footnotetext{
${ }^{62}$ CASSIRER, Ernst. Ensaio sobre o homem. Tradução de Tomás Rosa Bueno. São Paulo: Martins Fontes, 2005 , p. 144.

63 ANDRESEN, Sophia de Mello Breyner. Mar novo. Lisboa: Caminho, 2003, p. 28.

${ }^{64}$ KRISTEVA, Júlia. Sol negro: depressão e melancolia. Tradução de Carlota Gomes. Rio de Janeiro: Rocco, 1989.
} 
com as pupilas reviradas. Mas o mais estranho era a singular e apaixonante questão que a visão desse cadáver de supliciado sugeria [...]. Mesmo não querendo, dizemos: se a morte é uma coisa tão horrível, se as leis da natureza são tão poderosas, como podemos triunfar sobre elas? [...] Quando contemplamos esse quadro, imaginamos a natureza sob o aspecto de uma besta enorme, implacável e muda. [...] Ora, o que esse quadro pareceu exprimir foi essa noção de uma força obscura, insolente e estupidamente eterna, à qual tudo está sujeito, e que lhe domina, mesmo contra a sua vontade. Os homens que cercavam o morto, embora o quadro não representasse nenhum deles, devem ter sentido uma angústia e uma consternação horríveis, nessa noite que quebrava de uma só vez com todas as suas esperanças e quase com sua fé. 65

A descrição muito próxima da decomposição factual de um cadáver, segundo Júlia

Kristeva, tem por finalidade comunicar os dolorosos sentimentos de consternação, nojo, repulsa e angústia que o Duque de Gandia também sentiu ao ver o cadáver em decomposição de D. Isabel:

A representação sem disfarce da morte humana, o desnudamento quase anatômico do cadáver, comunica aos espectadores uma angústia insuportável diante da morte de Deus, aqui confundida com a nossa própria morte, de tanto que está ausente a menor sugestão de transcendência. [...] A humanização atinge assim o seu ponto mais alto: o ponto da extinção da glória na imagem. ${ }^{66}$

O eu lírico nos diz que a morte é "nojo e negação" no sentido de ir contra o nosso pensamento de imortalidade, pois até mesmo a beleza, que este pensava ser eterna, está sujeita a constante mudança que o tempo impõe: "Porque eu amei como se fossem eternos / A glória, a luz e o brilho do teu ser".

O poema "No tempo dividido", do livro de mesmo nome de 1954, fala também da ação destruidora do tempo:

E agora ó Deuses que vos direi de mim?

Tardes inertes morrem no jardim.

Esqueci-me de vós e sem memória

Caminho nos caminhos onde o tempo

Como um monstro a si próprio se devera. ${ }^{67}$

\footnotetext{
${ }^{65}$ KRISTEVA, Júlia. Sol negro: depressão e melancolia. Tradução de Carlota Gomes. Rio de Janeiro: Rocco, 1989, p. 104.

${ }^{66}$ Ibidem, p. 105-109.

${ }^{67}$ ANDRESEN, Sophia de Mello Breyner. No tempo dividido. Lisboa: Caminho, 2005, p. 38.
} 
O poema traz à tona a indignação e mágoa do eu lírico, na sua condição de mortal, para com os Deuses na pergunta irônica do primeiro verso: "E agora ó Deuses que vos direi de mim?" O tempo cronológico, porém, indiferente aos questionamentos do eu lírico continua sua antiqüíssima tarefa: “Tardes inertes morrem no jardim”.

O sujeito, em resposta, reveste-se de uma das qualidades pertinentes à memória e a morte: o esquecimento. Ao esquecer o domínio do tempo e não procurar o passado através da memória, o eu lírico passa a viver apenas o instante, carpe diem. Maurice Blanchot no livro $O$ Espaço Literário, fala do fascínio que a ausência do tempo provoca: "Escrever é entregar-se ao fascínio da ausência de tempo. Neste ponto, estamos abordando, sem dúvida, a essência da solidão." ${ }^{68} \mathrm{O}$ tempo cronológico das tardes finitas do jardim cede espaço para o tempo cíclico do Uróboro, a serpente que morde a própria cauda.

Mauro Maldonato cita o ensaio feito por Massimo Cacciari sobre algumas pinturas de Hogarth e Goya, nas quais presentifica-se a figura mítica de Cronos, que anuncia a própria morte contra o desejo de imortalidade do homem:

Na pintura de Hogarth, a clepsidra está vazia, o mundo, dissolvido num monte de escombros fumegantes. Na de Goya, o tempo tem o rosto da loucura, da cobiça extrema que leva a devorar os próprios filhos, eles que garantem sua existência. Ambos fazem alusão a um tempo que, por sua vontade de viver, lança-se ao encontro de sua própria destruição. A figura de Goya trai um escárnio inquietante, um riso alienado que observa, inerte, a própria autodestruição. "O tempo voraz" escreve Cacciari, "desvela a inverdade da pretensão humana a ter valores imortais e imutáveis." 69

Maria João Borges também analisou a "Meditação do Duque de Gandia sobre a morte de Isabel de Portugal" com uma leitura que analisa o horror a partir do medo que a perda do ser amado para a morte causa no eu lírico, subjugando até mesmo o amor, o tornando finito:

A consciência da morte-por-vir do ser amado é, já de si, intolerável [...]. O poema de Sophia exacerba esse sentimento, ao cruzar o testemunho amoroso, eloqüente [...]

\footnotetext{
${ }^{68}$ BLANCHOT, Maurice. O espaço literário. Tradução de Álvaro Cabral. Rio de Janeiro: Rocco, 1987, p.20.

${ }^{69}$ MALDONATO, Mauro. A subversão do ser. Tradução de Luciano Loprete e Roberta Barni. São Paulo: Peirópolis, 2002, p. 112.
} 
com o horror da decomposição [...], que compreende à perda total do ser amado: a morte é sentida como mais que uma separação, porque, destruindo a imagem do tu, consome a sua memória. [...] Em Sophia não existe esse tempo que resta, apenas o momento traumático, a consciência da morte que é a descoberta de um logro: "Porque eu amei como se fossem eternos..." A violência convulsa do poema de Sophia assentará porventura na racionalização à outrance, a que dá voz, da irracionalidade que é a morte do Outro [...]. ${ }^{70}$

A perplexidade e a negação são expressas pelo eu lírico, quando este repete várias vezes no decorrer do poema, a expressão "nunca mais", qual inicia vários versos do poema: "E nunca mais darei ao tempo a minha vida", "Nunca mais servirei senhor que possa morrer" (o mesmo verso se repete no final do poema), "Nunca mais amarei quem não possa viver / Sempre”. Assim, o tempo impõe a todos uma tirania: toda a nossa existência está inscrita na experiência do seu fluir, sendo que "O tempo é uma linguagem de separação", como afirma Mauro Maldonato:

O discurso sobre a morte é um discurso de múltiplas perspectivas. [...] A morte e o homem que vai ao seu encontro, paradoxalmente nunca se encontram, a não ser no melancólico e na experiência do pânico. Ali, com efeito, há um encontro. Mas, como demonstrou magistralmente Bruno Callieri, é um encontro com o nada. ${ }^{71}$

Este mesmo tema da finitude, da morte do amor, está presente em outro poema, marcado pela ausência e negação, "De um amor morto”, do livro Geografia, de 1967:

\author{
$[\ldots]$ \\ De um amor morto não fica \\ Nenhuma memória \\ O passado se rende \\ O presente o devora \\ E os navios do tempo \\ Agudos e lentos \\ O levam \\ [...] \\ É apenas um facto \\ Que a eternidade ignora $^{72}$
}

\footnotetext{
${ }^{70}$ BORGES, Maria João. Em torno do conceito de poesia pura, Cinatti, Sophia e Eugênio de Andrade. Lisboa: Faculdade de Letras da Universidade de Lisboa, 1996, p. 347-348.

${ }^{71}$ MALDONATO, Mauro. A subversão do ser. Tradução de Luciano Loprete e Roberta Barni. São Paulo: Peirópolis, 2001, p. 146.

${ }^{72}$ ANDRESEN, Sophia de Mello Breyner. Geografia. Lisboa: Caminho, 2004, p. 41.
} 
O poema tem seu tema centrado no aspecto efêmero e transitório do amor. Este é marcado pela ausência. O amor, que geralmente no início apresenta-se como absoluto, incondicional e belo, é totalmente esvaziado em decorrência da falta de magia que a vida trivial do dia-a-dia impõe. O eu lírico marca o esvaziamento e ausência que o correr do tempo e o esquecimento causam a este "amor morto", através da escolha de expressões e palavras pontuais: “não fica”, “se rende”, “o devora”, “o levam”, “não deixa”, “ignora”.

A memória não recupera o que era antes este agora "amor morto". Sem importância é "apenas um facto / Que a eternidade ignora". Mauro Maldonato ressalta que: "Resistir à contingência do tempo, tornar contínuo o descontínuo: eis a incapacidade da memória."73

O tempo interior, contrário ao tempo linear, não é marcado nem pelos números do relógio, nem por nenhuma norma, pois está ligado à memória afetiva. Esta implica escolhas, seleção; desta forma o passado jamais poderá ser reconstruído na sua totalidade. Quando o sujeito olha para trás, para a sua vida emocionalmente, os aspectos levantados anteriormente agem, fazendo uma releitura do passado, como neste poema "Era o tempo", do livro O búzio de cós, de 1997:

\footnotetext{
Era o tempo das amizades visionárias Entregues à sombra à luz à penumbra $\mathrm{E}$ ao rumor mais secreto das ramagens Era o tempo extático das luas Quando a noite se azulava fabulosa e lenta Era o tempo do múltiplo desejo e da paixão Os dias como harpas ressoavam Era o tempo de oiro das praias luzidias Quando a fome de tudo se acendia. ${ }^{74}$
}

O poema é todo marcado pela afetividade de um eu lírico que, em determinado momento da vida, olha para trás e procura por seu passado. A expressão "Era o tempo..." pontua de maneira alternada o poema. Esta expressão inicia quatro versos alternados, o que

${ }^{73}$ MALDONATO, Mauro, A Subversão do ser. Tradução de Luciano Loprete e Roberta Barni, São Paulo: Peirópolis, 2001, p. 138.

${ }^{74}$ ANDRESEN, Sophia de Mello Breyner. O búzio de cós. Lisboa: Caminho, 1999, p. 13. 
indica a importância afetiva que impõe aos fatos. Impõe também um aspecto mágico e encantado. Portanto, este “era o tempo...” tem o poder cíclico do eterno retorno.

O poema fala do período da juventude, pois é quando a vida é impulsionada mais intensamente pelo desejo e pela paixão: "Quando a fome de tudo se acendia". A vontade de eternizar o que foi vivido que está presente na fórmula mágica "Era o tempo...", reforçada através das palavras: "extático", "lenta". Todos os adjetivos intensificam o seu aspecto mágico: o tempo é "extático das luas", "do múltiplo do desejo e da paixão"; a noite é "fabulosa e lenta", os dias são como "harpas".

O segundo verso - "entregues à sombra à luz à penumbra" - retifica o movimento pertinente à memória de desvelar e esquecer, de trazer as coisas para a "luz" ou mantê-las na "sombra" e na "penumbra" do esquecimento. Com este poema, entramos no outro tema deste capítulo: a Memória.

Memória (Mnemosýne, em grego) era uma deusa na Grécia Antiga e, segundo JeanPierre Vernant, tem uma função psicológica:

\begin{abstract}
A memória é uma função muito elaborada que atinge grandes categorias psicológicas, como o tempo e o $e u$. Ela põe em jogo um conjunto de operações mentais complexas, e o seu domínio sobre elas pressupõe esforço, treinamento e exercício. O poder de rememoração é, nós o lembramos, uma conquista [...]. ${ }^{75}$
\end{abstract}

Sua sacralização se dá em decorrência da importância que essa função teve para a civilização grega que tinha como marca a tradição oral ${ }^{76}$. Filha de Urano e de Gaia, foi amada por Zeus e as nove Musas nasceram desta união ${ }^{77}$. Mantinha uma estreita ligação com a

\footnotetext{
${ }^{75}$ VERNANT, Jean-Pierre, Mito e pensamento entre os gregos. Tradução de Haiganuch Sarian. São Paulo: Paz e Terra, 2002, p. 136.

${ }^{76}$ Ibidem, p. 136.

${ }^{77}$ KURY, Mário da Gama. Dicionário de mitologia grega e romana. Rio de Janeiro: Jorge Zahar Editor, 1999, p.270.
} 
função poética: ela conduzia o coro das Musas e possibilitava ao aedo entrar e sair livremente do passado.

Teócrito, poeta grego do século III a. C., escreve em um de seus poemas sobre a presença das Musas no poema "Idílio XI":

Outro fármaco não há que cure o amor, ó Nícias,

Nem unguento, segundo me parece, nem pó para aplacar

A não ser as Musas. Indolor e suave é este remédio

Para os homens, mas não é fácil de encontrar. ${ }^{78}$

A figura das Musas, no poema, é sinônimo da cura dos males. Os conceitos do belo e da harmonia eram muito importantes para os gregos antigos. A beleza da poesia é o melhor remédio para as dores da vida para o eu lírico. Porém, este avisa, apesar de ser um remédio “suave e indolor" para os homens, "não é fácil de encontrar".

A presença das Musas também tem importância relevante na poesia de Sophia Andresen e, assim como o Tempo, dá nome a um de seus livros, Musa, de 1994. A sua presença está relacionada a um fazer poético. O que as Musas ensinam para o eu lírico, é a arte de escutar o silêncio.

Memória e Musas representam simbolicamente a ambigüidade existente nas palavras, no fazer poético e no resgate do passado através da lembrança. Em "Arte Poética V", publicada no livro Ilhas, de 1989, a poeta Sophia Andresen explica que foi através da oralidade o seu primeiro contato com a poesia:

Na minha infância, antes de saber ler, ouvi recitar e aprendi de cor um antigo poema tradicional português, chamado Nau Catrineta. Tive assim a sorte de começar pela tradição oral, a sorte de conhecer o poema antes de conhecer a literatura. ${ }^{79}$

\footnotetext{
${ }^{78}$ Poesia grega de Álcman a Teócrito. Organização e tradução de Frederico Lourenço. Lisboa: Cotovia, 2006, p. 166.

${ }^{79}$ ANDRESEN, Sophia de Mello Breyner. Ilhas. Lisboa: Caminho, 2004, p. 76.
} 
Cremilda de Araújo Medina aponta para a importância que o contato primeiro com a poesia oral exerceu na sua obra:

Mas foi na narrativa oral de sua babá que aprendeu a valorizar as sílabas das palavras, sua sonoridade. "Os portugueses comem as sílabas. Eu não, porque ouvia poemas orais." Esse gosto pela oralidade, pela musicalidade da poesia, se projetou para toda a vida. ${ }^{80}$

Esta relação entre a palavra silabada e a oralidade, que esteve na base da formação poética de Sophia Andresen, é um dos fatores importantes em sua poesia. Sobre esta relação Silvina Rodrigues Lopes afirma que:

$\mathrm{Na}$ dicção, oral e escrita, dos poemas de Sophia, cada palavra se destaca no seu brilho de corpo emergente para o acordo. As palavras são silabadas, o que não é apenas uma maneira de cativar o vazio, mas também de nelas morar e demorar, de opor resistência aos usos da linguagem que não deixam rastro porque são só o conforme das repetições. ${ }^{81}$

Esse movimento "de morar e demorar" traz o acolhimento e o aspecto de eternidade que a memória tem com as coisas, conforme podemos verificar no poema "Intacta Memória" do livro No Tempo Dividido de 1954:

Intacta memória - se eu chamasse Uma por uma as coisas que adorei Talvez que a minha vida regressasse Vencida pelo amor que a lembrei. ${ }^{82}$

Quanto à forma, na sua regularidade métrica (versos decassílabos) e no uso de rimas, o poema estabelece certa musicalidade e ritmo pertinentes às cerimônias religiosas e as de magia, as quais dependiam do cantar da palavra mágica para acessar outras dimensões.

A presença do adjetivo "intacta" confere à memória o status de estar ao abrigo da transitoriedade e da contínua transformação que o tempo impõe a todos. $\mathrm{O}$ acesso à memória

\footnotetext{
${ }^{80}$ MEDINA, Cremilda de Araújo. Viagem à literatura portuguesa contemporânea. Rio de Janeiro: Nórdica, 1983, p. 183.

${ }^{81}$ LOPES, Silvina Rodrigues. “A afirmação silabada”. In: Jornal de letras, 2004, p. 10

${ }^{82}$ ANDRESEN, Sophia de Mello Breyner. No tempo dividido. Lisboa: Caminho, 2005, p. 26.
} 
está sujeita ao poder da palavra, “... se eu chamasse”. Portanto, é a linguagem que desvela, retirando da obscuridade do passado "uma por uma" das "coisas" que foram adoradas pelo eu lírico. A partícula "se", o verbo no subjuntivo "regressasse" e o advérbio "talvez" reforçam o caráter hipotético deste regresso. Ainda, o regresso ao passado é mediado pelo "amor" "Vencida pelo amor que a lembrei".

No poema "Varandas", do livro O búzio de Cós, de 1997, há um verso no qual o eu lírico declara: "Amei a vida como coisa sagrada." ${ }^{83}$ A respeito desse amor pela vida que a poesia de Sophia Andresen exprime, Maria João Borges afirma que torna a poesia o "registro de uma 'paixão", no qual:

O percurso do homem e o conhecimento que dele vai colhendo é soma de deslumbramento e perplexidade; a orientação, determinada pelo desejo ou paixão que inflama o sujeito, não elimina, nem o aleatório, de uma caminhada que se revela destino envolto pelo mistério. ${ }^{84}$

A rememoração envolvida pelo amor é meio para atingir o fundo do seu ser como prerrogativa fundamental para compreender o presente e viver o devir em busca de totalidade.

Para Alfredo Bosi, no ensaio "Tempo e Tempos" (Tempo e história, de 1992), a linguagem permite à memória articular e organizar-se formalmente, adquirindo, assim, um caráter duradouro, que resiste ao tempo: a imortalidade. É através dela que podemos resgatar todos que já se ausentaram, superando qualquer linha ou limite de tempo:

A memória articula-se formalmente e duradouramente na vida social mediante a
linguagem. Pela memória as pessoas que se ausentaram fazem-se presentes. Como
passar das gerações e das estações esse processo "cai" no inconsciente lingüístico,
reaflorando sempre que se faz uso da palavra que evoca e invoca. É a linguagem que
permite conservar e reavivar a imagem que cada geração tem da anterior. Memória e

\footnotetext{
${ }^{83}$ ANDRESEN, Sophia de Mello Breyner. O búzio de cós. Lisboa: Caminho, 1999, p. 20.

${ }^{84}$ BORGES, Maria João. Em torno do conceito de poesia pura, Cinatti, Sophia e Eugênio de Andrade. Lisboa: Faculdade de Letras da Universidade de Lisboa, 1996, p. 258.
} 
palavra, no fundo inseparáveis, são a condição de possibilidade do tempo reversível. $^{85}$

Jean-Pierre Vernant lembra que, para se entrar em contato com o passado, é necessário o esquecimento do tempo presente, sendo que, este "esquecer" tem o valor simbólico de “morrer" para o presente. ${ }^{86}$

A alternância que o fluxo da memória impõe faz com que o eu lírico nos poemas andresianos construa certos espaços simbólicos. As imagens da casa e do jardim protegidos da voracidade do fluir do tempo adquirem uma atmosfera melancólica. Até mesmo a varanda ganha uma aura toda especial quando resgatada pela memória para reviver momentos da juventude, como podemos verificar nesses versos do poema "Varandas", do livro O búzio de cós, de 1997:

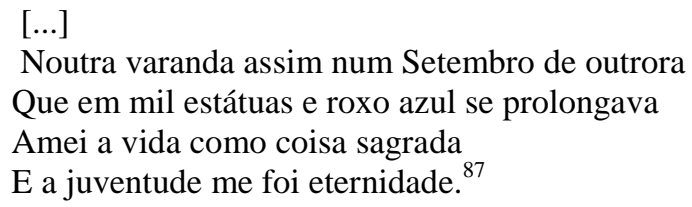

A "varanda" está toda mergulhada em uma aura de nostalgia, como parte da vida que já ficou para trás, assim "num Setembro de outrora". As cores, "roxo e azul”, intensificam o clima melancólico e saudosista que permeia o poema, pois podem indicar o período do cair da tarde. As palavras, "sagrada" e "eternidade", reforçam a ideia de valor afetivo que as recordações "da juventude" possuem para o eu lírico. Sobre a presença das "estátuas" no poema, Maria de Fátima Marinho lembra que elas possuem uma função especial na obra andresiana:

\footnotetext{
${ }^{85}$ BOSI, Alfredo. "O tempo e os tempos". In: Tempo e história, organização de Adauto Novaes São Paulo: Companhia das Letras, 1992, p. 28.

${ }^{86}$ VERNANT, Jean-Pierre. Mito e pensamento entre os gregos. Tradução de Haiganuch Sarian. São Paulo: Paz e Terra, 2002, p. 154.

${ }^{87}$ ANDRESEN, Sophia de Mello Breyner. O búzio de cós. Lisboa: Caminho, 1999, p. 20.
} 
A morte vai sendo indicado através de algum de seus avatares, como demonstra a recorrência dos tópicos da estátua e da máscara que desembocam na experiência do vazio e do exílio que levam directamente à morte. ${ }^{88}$

A casa, na poesia de Sophia Andresen, torna-se um espaço que acolhe as lembranças do eu lírico, por se tratar de um lugar permeado de intimidade e proximidade afetiva, gerando no sujeito um sentimento profundo de proteção. Ao analisar a questão fenomenológica da simbologia do espaço com relação à figura da casa, Gaston Bachelard no livro A poética do espaço $^{89}$, aponta que:

$\mathrm{Na}$ vida do homem, a casa afasta contingências, multiplica seus conselhos de continuidade. Sem ela, o homem seria um ser disperso. Ela mantém o homem através das tempestades do céu e das tempestades da vida. É corpo e é alma. É o primeiro mundo do ser humano. [...] A vida começa bem, começa fechada, agasalhada no regaço da casa. ${ }^{90}$

A estrutura física da casa como espaço concreto é metáfora para o espaço subjetivo do exercício mental da memória, transformando ausências em presenças. É esse processo que ocorre no poema "Casa", presente no livro Geografia, de 1967:

\footnotetext{
A antiga casa que os ventos rodearam

Com suas noites de espanto e de prodígio

Onde os anjos vermelhos batalharam

A antiga casa de inverno em cujos vidros

Os ramos nus e negros se cruzavam
}

Sob o íman dum céu lunar e frio

Permanece presente como um reino

E atravessa meus sonhos como um rio. ${ }^{91}$

No poema, o objeto de recordação por parte do eu lírico é a casa antiga de inverno. Todos os elementos resgatados pela memória do sujeito são elementos materiais: a "casa", as

\footnotetext{
${ }^{88}$ MARINHO, Maria de Fátima. "Sophia de Mello Breyner Andrese: um original cruzamento de tendêncas". In: Máthesis. Disponível em <www.4.crb.ucp.pt/Mathesis/Mat10/mathesis10_50.pdf>. Acesso em 21/06/2010.

89 BACHELARD, Gaston. A poética do espaço. Tradução de Antonio de Pádua Danesi. São Paulo: Martins Fontes, 1996.

${ }^{90}$ Ibidem, p. 26.

${ }^{91}$ ANDRESEN, Sophia de Mello Breyner. Geografia. Lisboa: Caminho, 2004, p. 51.
} 
"noites", "os anjos vermelhos", "os ramos nus e negros", o "céu lunar e frio" e "reino". Não há nenhuma indicação de lembrança relacionada a alguma pessoa em especial. Há apenas a casa antiga de inverno.

O uso do adjetivo "antiga", para qualificar a casa, permite pensar que essa casa, materializada no poema, remete às lembranças ligadas à infância do eu lírico. O segundo verso, "Com suas noites de espanto e de prodígio", tende a colaborar para a intensificação desta ideia, visto que as locuções adjetivas "de espanto e de prodígio" que caracterizam "as noites” expressam certa atmosfera fantástica e mágica muito pertinente à infância.

A escolha por determinados elementos e a descrição fantasmagórica com que eles são descritos pelo sujeito remetem ao mundo onírico, como, por exemplo, os "anjos vermelhos", cuja cor causa estranheza, beirando quase a imagem de uma assombração, o que contradiz a imagem protetora que os anjos transmitem.

"Os ramos nus e negros" que se cruzavam ao bailado do vento, vistos através dos vidros de possíveis janelas, no período noturno (fato que implica pouca iluminação), configuram o clima fantasmagórico que atravessa o poema.

Na última estrofe, podemos perceber como a imagem desta "casa antiga de inverno" possui uma presença muito intensa nas recordações do eu lírico. Mesmo estando descrita sob um "céu lunar e frio", ela exerce um poder de atração muito intenso figurado na metáfora que liga o íman e o céu. $\mathrm{O}$ íman é um mineral ferromagnético, que geralmente apresenta a cor acinzentada, muito próxima à cor do céu em alguns momentos do inverno. A cor cinza, contrariamente à cor vermelha dos anjos, transmite uma sensação de frieza, mas também de tranquilidade, apesar de certo caráter negativo. 
No segundo verso da última estrofe "Permanece presente como um reino", o verbo “permanece", conjugado no presente, presentifica a lembrança desta "casa antiga". É o tempo do fluir interno da subjetivação, onde o contínuo passa a ser descontínuo, re-elaborado e transformado pela memória afetiva interna, que não é controlado por limite temporal linear.

A categoria espacial, aqui, também é subvertida pelo tempo interior, pela memória afetiva, pela imaginação e linguagem poética, que transformam a casa de inverno em um reino, tirando qualquer possibilidade de qualificação usual ou comum desta "casa antiga de inverno" com outras, fato que aponta para o caráter único e pessoal afetivo na valorização da casa, ou talvez, da imagem que aqui no poema ela traz junto de si, a imagem sacralizada da infância. É como se a casa mantivesse o espaço do tempo da infância imóvel "em seus braços" $" 92$.

No último verso ("E atravessa meus sonhos como um rio"), o caráter onírico e subjetivo desta memória é confirmado pela presença da expressão “meus sonhos". A figura da “casa antiga de inverno" é espaço de integração das lembranças e dos sonhos, e desta união a figura, ao ser modificada pela memória afetiva, retifica o caráter onírico da mesma: A casa como o fogo, como a água, nos permitirá evocar, na sequência de nossa obra,
luzes fugidias de devaneio que iluminam a síntese do imemorial com a lembrança.
Nessa região longínqua, memória e imaginação não se deixam dissociar.

O pronome "meus" reforça o caráter particular das experiências vividas pelo eu lírico. É justamente esse caráter particular e individual da experiência no decorrer do tempo que Mauro Maldonato ressalta ao comentar como os teóricos Hursserl, Minkowiski e Lévinas entre outros, pensam a construção temporal das experiências vividas:

\footnotetext{
92 BACHELARD, Gaston. A poética do espaço. Tradução de Antonio de Pádua Danesi. São Paulo: Martins Fontes, 1996, p. 26.

${ }^{93}$ Ibidem, p. 25.
} 
[...] levam a questão da temporalidade para o campo de forças do tempo vivido, do tempo vivido do outro, das diferentes experiências vividas que se encontram "cara a cara" no mundo. Com a fenomenologia, a figura do outro, por mais estranha e inapreensível que seja, está reinscrita no tempo, embora sem que o tempo a possua. O tempo é sempre somente o tempo de um homem que o experiencia. O tempo é, portanto, irredutivelmente, o meu tempo, tempo desmedidamente diferente do tempo do outro. ${ }^{94}$

A imagem da casa, em vários poemas andresianos, apresenta-se como símbolo de unidade, de espaço mágico e assombro em relação à memória no decorrer do tempo (geralmente tendo o espaço noturno como mediador dessa unidade, o que ressalta o caráter imaginário e onírico que esta imagem assume), como podemos verificar nestes versos da quarta estrofe do poema "Portas da Vila", presente também no livro Geografia: "A casa jaz com mil portas abertas / O interior dos armários é obscuro e vazio". 95

O sentimento de vazio, que a ausência provoca, também está relacionado diretamente à poesia de Sophia Andresen. Eduardo Prado Coelho afirma que há um esforço muito intenso, “impossível” por parte da poesia, "peregrinando de coisa em coisa" em transformar a ausência em presença ${ }^{96}$.

Vejamos o poema "Carta a Maria do Carvalhal Alvito", do livro Ilhas de 1989:

Querida Maria - subitamente o fino
Deste primeiro frio misturado
Com um sabor de lenha e maçã
Algo recorda: tacteio na memória
Procurando o onde o quando o quem
E a tua casa reabre de repente as suas portas
E caminho nos quartos entre
Os raios da luz e o cismar das penumbras
E vens ao meu encontro e és meu abrigo
Pranto e saudade em cada gesto irrompem
Mas a irreversível alegria do ter sido
Não deixará jamais de estar comigo
E há um sabor de lenha e de maçã

\footnotetext{
94 MALDONATO, Mauro. A subversão do ser. Tradução de Luciano Loprete e Roberta Barni. São Paulo: Peirópolis, 2001, p. 121.

${ }^{95}$ ANDRESEN, Sophia de Mello Breyner. Geografia. Lisboa: Caminho, 2004, p. 53.

${ }^{96}$ COELHO, Eduardo Prado, A palavra sobre a palavra. Porto: Portucalense, 1972, p. 229.
} 
E o tempo é jovem próximo e amigo

E rimos juntas nesse dia antigo

E entro na tua casa e és meu abrigo

Lisboa, Novembro de $1986^{97}$

Primeiro ponto a ser ressaltado, ao ler o poema, é que, ao contrário de boa parte a sua obra, onde há uma preocupação intensa por parte da poeta para se desvencilhar da voz que fala no poema, neste o eu lírico assume a voz que fala através dos versos. Esse fato aponta para um tom mais intimista.

O poema é composto de uma única estrofe de versos livres, sem homogeneidade na metrificação, o que passa a ter um significado especial: fazer com que a linguagem poética aproxime-se ao máximo da oralidade presente no texto de uma carta.

Como no livro Em busca do tempo perdido - no caminho de Swann ${ }^{98}$, de Marcel Proust, na famosa cena em que Swann, ao mergulhar um pedaço de bolo (madaleine) na xícara de chá, deixa-se guiar pela memória, o eu lírico, no poema andresiano, a partir das sensações que o frio evoca, como o "sabor de lenha e maçã", vê-se mergulhado no passado. Ou seja, a partir de um estímulo externo, abre-se uma fratura no tempo presente e o tempo interno, através da memória, tenta reconstruir o passado.

A expressão "algo recorda" confirma que é um estímulo externo, que impulsiona o exercício da lembrança, “com um sabor de lenha e maçã”. A surpresa contida na expressão “de repente" aponta o movimento involuntário da memória: "E a tua casa reabre de repente as suas portas". Novamente, a imagem da casa é um espaço centralizador das memórias afetivas.

\footnotetext{
${ }^{97}$ ANDRESEN, Sophia de Mello Breyner. Ilhas. Lisboa: Caminho, 2004, p. 58.

${ }^{98}$ PROUST, Marcel. Em busca do tempo perdido - no caminho de Swann. Tradução de Mario Quintana. São Paulo: Globo, 2008, p. 71.
} 
Nos versos sétimo e oitavo do poema, a ação de caminhar nos "quartos entre / os raio da luz e o cismar das penumbras", é uma metáfora dos caminhos tortuosos da memória do lembrar e esquecer.

Ernst Cassirer lembra a complexidade e profundidade que envolve o fenômeno da memória simbólica, ao citar Bergson:

Ela significa “interiorização" e "intensificação"; significa a interpenetração de todos os elementos de nossa vida passada. [...] é um processo pelo qual o homem não só repete sua experiência passada, mas também reconstrói essa experiência. A imaginação torna-se um elemento necessário da verdadeira lembrança. ${ }^{99}$

Como vimos anteriormente, os versos oitavo e nono do poema apresentam um jogo de "revelação e ocultação" muito próprio da memória: "Os raios de luz e o cismar das penumbras / E vens ao meu encontro e és meu abrigo." Aqui temos a concepção clássica da memória: aletheia é desvelamento, luz, e léthe é esquecimento, escuridão, noite, domínio dos mortos. É deste movimento entre luz e escuridão que o objeto de recordação vem até o eu lírico. Octávio Paz afirma que "a poesia é revelação de nossa condição e, por isso mesmo, criação do homem pela imagem. Revelação é criação."100

O contato com a lembrança de alguém que faz parte do passado faz surgir uma profusão de emoções: “[...] és abrigo / Pranto e saudade em cada gesto irrompem”. A lembrança revela-se acolhedora, melancólica e saudosa. Embora haja uma conscientização por parte do sujeito de que a volta ao passado é "irreversível”, existe a sensação forte da “[...] alegria do ter sido", que é o pilar de sustentação da memória.

Alfredo Bosi colocou de forma clara e brilhante a interdependência entre memória e poesia:

\footnotetext{
${ }^{99}$ CASSIRER, Ernst. Ensaio sobre o homem. Tradução de Tomás Rosa Bueno. São Paulo: Martins Fontes, 2005, p. 89.

${ }^{100}$ PAZ, Octávio. O arco e a Lira. Tradução de Olga Savary. Rio de Janeiro: Nova Fronteira, 1982, p. 189.
} 
Nessa perspectiva, a instância poética parece tirar do passado e da memória o direito à existência, não de um passado cronológico puro - o dos tempos já mortos - mas de um passado presente cujas dimensões míticas se atualizam no modo de ser da infância e do inconsciente. ${ }^{101}$

No poema "No Quarto” presente no livro Geografia, de 1967, o verso final, “A nossa vida é como um vestido que não cresceu connosco" ${ }^{\text {"102, }}$, expressa uma sensação angustiante que nos é muito comum: a sensação de que o tempo parece ser pequeno diante do nosso intenso desejo de viver e de que a nossa já não nos basta. Este sentimento é pertinente a quem está olhando para traz a partir de um determinado momento da vida. Daí o desconforto.

Em uma pequena narrativa, “A Próxima Aldeia”, do livro Um Médico Rural, de Franz Kafka, o narrador expressa um sentimento em relação à duração do tempo da vida muito próximo ao que o eu lírico descreve no verso andresiano:

Meu avô costumava dizer: "A vida é espantosamente curta. Para mim ela agora se
contrai tanto na lembrança que eu por exemplo quase não compreendo como um
jovem pode resolver ir a cavalo à próxima aldeia sem temer que - totalmente
descontados os incidentes desditosos - até o tempo de uma vida comum que
transcorre feliz não seja nem de longe suficiente para uma cavalgada como essa". ${ }^{103}$

A inquietude do narrador diante do tempo que não pára faz com que a vida passe a ser considerada como algo muito precioso e frágil. Toda uma vida transforma-se nas lembranças contraídas que a memória conseguiu armazenar. É a comprovação deste fato que faz surgir a indignação do avô, na sua incompreensão de como os jovens não conseguem mensurar a dimensão que este fato possui. Existe um verso da tragédia grega Medeia, de Eurípides, no qual a ama, diante do sofrimento da protagonista e o total desconhecimento deste pelos seus filhos, expressa o mesmo pensamento: "mente nova não se afina com dor."104

\footnotetext{
${ }^{101}$ BOSI, Alfredo. O ser e o tempo da poesia. Cultrix: São Paulo, 1993, p. 112.

102 ANDRESEN, Sophia de Mello Breyner. Geografia. Lisboa: Caminho, 2004, p. 47.

103 KAFKA, Franz. Um médico rural. Tradução de Modesto Carone. São Paulo: Companhia das Letras, 2003, p.40.

${ }^{104}$ EURÍPIDES. Medeia. Tradução de JAA Torrano. São Paulo: Hucitec, 1991, p. 33.
} 
Os sentimentos angustiantes e melancólicos que nascem em decorrência de um tempo que não pára e do desejo imenso de viver sempre mais, faz com que o eu lírico sonhe com o poder de dominar o seu fluxo, como está expresso no primeiro verso do poema "As Nereides" do livro Geografia, de 1967: "Pudesse eu reter o teu fluir, ó quarto"105.

Para finalizar este capítulo, gostaríamos de citar a fala de Octavio Paz sobre a poesia e a morte:

Entre o nascer e o morrer, a poesia nos abre uma possibilidade que não é a vida eterna das religiões nem a morte eterna das filosofias, mas um viver que envolve e contém o morrer, um ser isto que é também um ser aquilo. ${ }^{106}$

Assim, ao abarcar o movimento cíclico entre vida e morte, a poesia torna-se possibilidade de um sempre vir a ser, o nosso precioso e beatífico remédio que o poeta Teócrito sabiamente referenciou.

${ }^{105}$ ANDRESEN, Sophia de Mello Breyner. Geografia. Lisboa: Caminho, 2004, p.52.

${ }^{106}$ PAZ, Octavio Paz. O arco e a lira. Tradução de Olga Savary. Rio de Janeiro: Nova Fronteira, 1982, p. 188. 


\section{THÂNATOS E A NOITE}

A figura da noite, e todo o universo que a cerca, está entre os temas que compõem o universo poético andresiano. Esta tem uma presença mais frequente nos dois primeiros livros: Poesia, de 1944, e Dia do mar, de 1947, mas também a encontramos em boa parte de sua obra. O ambiente noturno, na poesia de Sophia Andresen, comporta uma atmosfera mágica, misteriosa, que inspira assombro, temor e espanto.

Para muitos críticos literários, é consenso a forte influência de poetas líricos como Rainer Maria Rilke na obra de Sophia Andresen. Eduardo Lourenço ${ }^{107}$ utiliza a metáfora do espelho e de Alice para caracterizar essa influência. Há um poema que traduz de forma muito clara a proximidade e a intimidade que se estabelecem entre o sujeito poético e a noite, na poesia de Rilke:

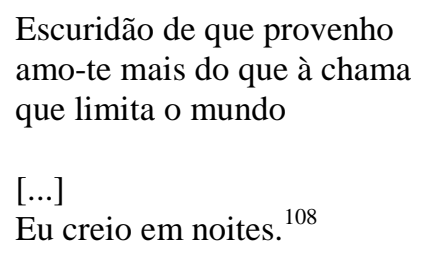

Aliás, a identificação do sujeito lírico com a noite é um antigo pensamento antigo. O guerreiro grego Aias, na peça de teatro de Sófocles ${ }^{109}$, de mesmo nome, depois de reconhecer o grave erro que cometera, identifica-se com a noite com a seguinte saudação:

\footnotetext{
Ah, escuridão, minha luz!

Trevas, que refulgentes sois para mim!

Tomai-me, tomai-me como vosso habitante,

Tomai-me! ${ }^{110}$
}

\footnotetext{
${ }^{107}$ LOURENÇO, Eduardo. "Para um retrato de Sophia". In: Antologia, Sophia de Mello Breyner Andresen. Lisboa: Moraes Editores, 1978.

${ }^{108}$ RILKE, Rainer Maria. Poemas e elegias de Diuno e sonetos a Orfeu. Tradução de Paulo Quintela. Porto: O Oiro do Dia, 2003, p. 92.

${ }^{109}$ SÓFOCLES, Aias. Apresentação e tradução de Flavio Ribeiro de Oliveira. São Paulo: Iluminuras, 2008.
} 
Joaquim Manuel Magalhães, ao analisar a obra de Sophia Andresen, aponta que o lirismo na poesia andresiana não contém um tom lírico "como veículo temático da poesia de amor". O mesmo podemos dizer sobre a imagética noturna, visto que esta não teria a presença de um léxico ligado ao amor propriamente dito:

[...] palavras de outros concretos: comportamento, matérias de coisas, lugares. Se aliarmos a esse léxico que se justapõe, o tom que dele se desprende, estaremos próximos de uma intencionalidade que procura medir o positivo e o negativo dos mundos interior e exterior a partir de uma dimensão maior, absoluta [...]. ${ }^{111}$

Em grande parte dos poemas o movimento textual que envolve a presença da noite é atravessado por uma atmosfera tensa, sombria, densa, mágica da escuridão noturna, mesmo quando o cenário que esta retrata é o "jardim". O excesso na descrição do universo que o forma é carregado com uma tensão latente, às vezes sufocante, como, por exemplo, nos poemas “A Noite e O Jardim" e "Noite”, que serão analisados depois.

O cair da escuridão noturna faz com que desapareçam na escuridão todas as coisas da terra. É o espaço de esquecimento, que, embora traga o terror e o medo do desconhecido, seduz e fascina por ser a possibilidade de contato com um todo que é o outro, permitindo o eterno retorno das coisas primitivas e anteriores. Em alguns poemas, como em "A Flauta" do livro Geografia, de 1967, este movimento é nomeado metaforicamente de "navegação": "Estava o anel da noite solenemente posto no meu dedo / e a navegação do silêncio continuou sua viagem antiquíssima."112

A noite, na poesia de Sophia Andresen, é fonte de inspiração e imaginação, momento mágico, espaço poético fértil, fascinante, acolhedor. Contém a força que impulsiona o ir

\footnotetext{
${ }^{110}$ FIALHO, Maria do Céu Zambujo. Luz e trevas no teatro de Sófocles. Coimbra: Centro de Estudos Clássicos de Coimbra, 1992, p. 27.

${ }^{111}$ MAGALHÃES, Joaquim Manuel. Rima pobre. Lisboa: Presença, 1999, p. 46.

${ }^{112}$ ANDRESEN, Sophia de Mello Breyner. Geografia. Lisboa: Caminho, 2004, p. 45.
} 
"além de". O espaço noturno é dimensão do vazio, do silêncio fecundo de incessantes murmúrios, onde o ser desfaz-se, unindo-se aos elementos de um mundo suprimido.

Entre os poemas que compõem o livro Coral, de 1950, contém um que permite perceber alguns pontos aqui levantados:

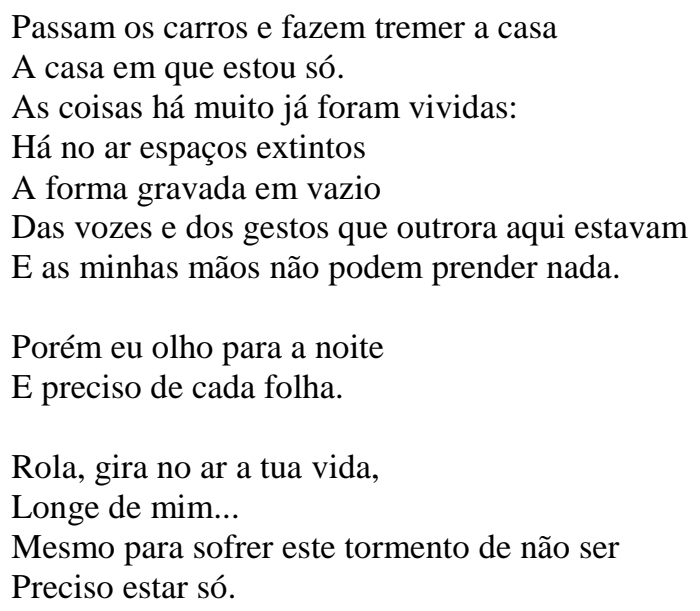

\begin{abstract}
Antes a solidão de eternas partidas De planos e perguntas, De combates com o inextinguível Peso de mortes e lamentações Antes a solidão porque é completa.
\end{abstract}

Creio na nudez da minha vida.

Tudo quando me acontece é dispensável.

Só tenho o sentimento suspenso de tudo

Como a eternidade a boiar sobre as montanhas. ${ }^{113}$

O poema acima é composto por um léxico marcado pela ausência que o eu lírico vivencia no contato com a noite: "só", "vazio", "nada”, "solidão”, “nudez”, "espaços extintos”, “eternas partidas”, “dispensável”, “longe”, mortes, “não ser”. As perdas pelas quais o eu lírico passou estão registradas nos versos: “As coisas há muito já foram vividas”; "Das vozes e dos gestos que outrora aqui estavam" e "Só tenho o sentimento suspenso de tudo".

${ }^{113}$ ANDRESEN, Sophia de Mello Breyner. Coral. Lisboa: Caminho, 2005, p.23. 
A melancolia é decorrente do tempo cruel que não cessa seu movimento (motivo visto no primeiro capítulo), também presente nos versos: "Passam os carros e fazem tremer a casa" e "Rola, gira no ar a tua vida". A sucessão contínua dos eventos marca a perda das coisas que já foram vividas. O vazio é preenchido pelas vozes e gestos "que outrora aqui estavam". Todos esses elementos, aliados à impossibilidade do eu lírico de realizar alguma ação que impeça essas perdas, intensificam o sentimento melancólico: “e as minhas mãos não podem prender nada”. Existir é estar fadado a perecer, e perecer é sinônimo de separação e dor.

Em cada verso, há marcas da presença consciente da morte, principalmente em "do tormento de não-ser", marcando o trágico destino mortal do homem e de todos os seres da terra. A partir desta interiorização do vir a "não-ser", o sujeito lírico experimenta o vazio e a solidão que se intensifica através do verso: “A forma está gravada no vazio”. Maria João Borges, ao analisar a experimentação da morte dos outros por parte do eu lírico através da ausência, aponta que o vazio na poesia andresiana "abre o caminho à negação da plenitude $[\ldots] ., 114$

Apesar do sofrimento que esta experiência do vazio proporciona ao sujeito lírico, trazendo a conscientização do "tormento de não ser", da perda das coisas que já "foram vividas", o contato com a solidão é necessário. Essa necessidade está inscrita através do verbo "precisar" na segunda e terceira estrofes do poema: "e preciso de cada folha" e "preciso estar só". Ciente do seu caráter efêmero, como em uma profissão de fé, ratifica-se e justifica-se sua escolha pela solidão:

\footnotetext{
${ }^{114}$ BORGES, Maria João. Em torno do conceito de poesia pura, Cinatti, Sophia e Eugênio de Andrade. Lisboa: Faculdade de Letras da Univrsidade de Lisboa, 1996, p. 311.
} 


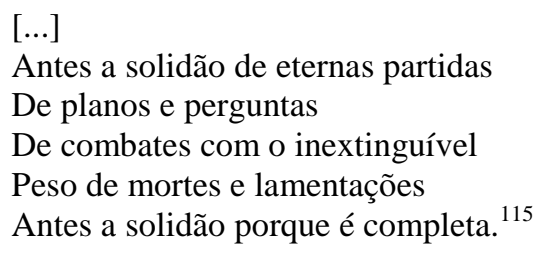

Diante da certeza da perda e da efemeridade das coisas e de si próprio, sabendo-se finito, o sujeito lírico tenta minimizar essa situação negativa ao contrapor e contemporizar a nulidade, supervalorizando “a solidão". Primeiro, apesar de toda a dor, prefere a solidão, pois esta é fruto da eterna perda das coisas que teremos fatalmente durante a vida. Depois, qualifica solidão com o adjetivo "completa", o que indica sua concretude dolorosa em oposição ao vazio das coisas.

É essa atitude corajosa que impulsiona o eu lírico e como em uma profissão de fé, reforça a sua crença na vida, "Creio na nudez da minha vida. / Tudo o que me acontece é dispensável", novamente relativizando-a em relação à "eternidade" que bóia por "sobre as montanhas". No entanto, toda esta situação de vazio, de solidão intensa diante da finitude concreta que é a morte, só pode ser construída e vivenciada a partir da presença da noite: “porém eu olho para a noite". É seu aspecto mágico e misterioso que assegura ao sujeito lírico, com a eliminação das fronteiras, a possibilidade de ir ao encontro do impossível e da poesia: "e preciso de cada folha". Podemos traçar um paralelo com a análise Walter Benjamin em relação ao processo criativo de Marcel Proust no livro Em busca do tempo perdido $^{116}$ :

Por pouco, poderíamos chamá-la uma hora que repete-se todos os dias. Ela vem com a noite, com um arrulho perdido, ou com a respiração na balaustrada de uma janela aberta. Não podemos prever os encontros que nos estariam destinados se nos submetêssemos menos ao sono. Proust não se submetia ao sono. [...] Submetendo-se à noite, Proust vencia a tristeza sem consolo de sua vida interior $[\ldots]^{117}$

\footnotetext{
115 ANDRESEN, Sophia de Mello Breyner. Coral. Lisboa: Caminho: 2005, p. 23.

116 PROUST, Marcel. Em busca do tempo perdido: no caminho de Swann. Tradução de Mário Quintana. São Paulo: Globo, 2008.

${ }^{117}$ BENJAMIN, Walter. Obras escolhidas, magia e técnica, arte e política. Tradução de Sergio Paulo Rouanet. São Paulo: Brasiliense, 2010, p. 38.
} 
Na mitologia grega, a Noite $(N y x)$ é uma das divindades da primeira geração dos deuses. Representa as forças primitivas, primordiais, juntamente a Gaia, Tártaro, Eros e Érebo. Da união entre Noite e Érebo surgiram as duas entidades luminosas: Éter (Luz Etérea, a luminosidade da região superior da atmosfera) e Hémera (o Dia, a luminosidade que brilha em cima da terra). Os contrários asseguram a harmonia e o equilíbrio no universo: noite/escuridão-dia/luminosidade. Não há dia sem noite e nem noite sem dia: "Tudo acaba na noite, é por isso que existe dia." $" 118$

A divindade da Noite, na mitologia grega, é mãe dos gêmeos Hipnos e Thânatos. Assim, na sua raiz mais primitiva existe uma ligação com a morte. Há algumas representações imagéticas dos dois irmãos, carregando os mortos, conduzindo-os para o reino das sombras, ou mais atuais, como o quadro de John William Waterhouse, em que os dois foram retratados dormindo. Paul De Saint-Victor, em seu livro As duas máscaras, cita o famoso relevo no cofre de Cípselo, encontrado por Pausânias, geógrafo e mitógrafo grego do séc. II a.C., onde a Noite tinha em seus braços um filho branco, Hipnos, e um negro, Thânatos:

Fraternalmente adormecidos em seu seio tranquilo. Abraçados, confundidos, colavam-se pelos lábios e misturavam seus sonhos. Tânatos só se distinguia do irmão pela cor e pelos pés deslocados, símbolo do movimento da vida torcido pela morte. ${ }^{119}$

Hipnos, como personificação do sono, é potência que no decorrer da noite estabelece dimensões outras, onde vivos e mortos podem conviver em uma transição sem limites de barreiras: o vivo se transforma em morto e o morto em vivo.

\footnotetext{
${ }^{118}$ BLANCHOT, Maurice. O espaço literário. Tradução de Álvaro Cabral. Rio de Janeiro: Rocco, 1987, p.167. ${ }^{119}$ SAINT-VICTOR, Paulo de. As duas máscaras: tragédia - comédia. Tradução de Gilson César Cardoso de Souza. São Paulo: Germape, 2003, p. 536-537.
} 
Octávio Paz ressalta que o poema é o lugar de encontro entre a poesia e o homem ${ }^{120}$ e que a poesia alimenta-se da "linguagem viva de uma comunidade, de seus mitos, sonhos e paixões." ${ }^{21}$ Assim, o poema acolhe em seu espaço os conceitos míticos da Noite que, no decorrer dos tempos, são filtrados de diferentes maneiras. Não pensamos mais na noite como uma deusa ou uma entidade mítica tal qual era para os gregos antigos, mas muito do que representou ainda hoje sobrevive nas camadas mais profundas da nossa imaginação. Sua magia não cessa nunca e seu poder de sedução e mistério nos arrasta aos limites de seus domínios.

A imagem da Noite, na poesia de Sophia Andresen, pode manter alguns traços específicos como, por exemplo, do ambiente noturno que propicia a transfiguração de um universo real para o onírico. Geralmente, os poemas de atmosfera noturna apresentam certa regularidade na composição do cenário: seus elementos estão profundamente ligados à natureza, com suas árvores e folhagens, o jardim, a presença da lua, os astros. A água (rios e fontes) e o vento possuem a função de murmurar e gerar alguma ação em um ambiente inerte, no mover das folhas ou no passar por entre pátios e adros vazios.

O jardim, inserido no ambiente noturno, também é metáfora para o silêncio, como podemos verificar nos versos do poema "Partida", do livro Dia do Mar, de 1947: "E tens o silêncio dum jardim / Invadido de luar e de segredos."122

A imagem da cidade aparece em alguns poemas de atmosfera noturna, mas possuem uma conotação extremamente negativa e sufocante. A noite torna o espaço urbano perigoso para a vida em muitos poemas andresianos, como no poema "Cidade", do Livro Sexto, de 1962:

\footnotetext{
${ }^{120}$ PAZ, Octávio, O arco e a lira. Tradução de Olga Savary. Rio de Janeiro: Ed. Nova Fronteira, 1982, p.50. ${ }^{121}$ Ibidem, p.49.

${ }^{122}$ ANDRESEN, Sophia de Mello Breyner. Dia do mar. Lisboa: Caminho, 2003, p. 44.
} 
As ameaças quase visíveis surgem

Nascem

Do exausto horizonte mortas luas

E estrangulada sou por grandes polvos

Nas tristezas das ruas ${ }^{123}$

O poema desenha um cenário urbano ameaçador, sem esperança e devastador, refletido nas imagens "do exausto horizonte", das "mortas luas", do polvo ${ }^{124}$ que, com seus vários braços, asfixia e estrangula qualquer possibilidade de vida. É um território marcado pela tristeza e tensão. Nem mesmo a lua, imagem extremamente lírica, traz um alento ao poema, pois estão mortas, no espaço de um horizonte "exausto" que não inspira nenhuma esperança. O poema, quanto a sua forma, é construído com versos livres, sem uma regularidade métrica, o que pode indicar uma intencionalidade, por parte do eu lírico, na representação caótica e angustiante dos ambientes urbanos.

Situação completamente diferente encontramos nos poemas em que o cenário noturno tem como personagem o mundo dos jardins e a exuberante vegetação que estes comportam. Um exemplo é o poema "Noite", do livro Poesia, de 1944. Neste poema, estão presentes vários elementos que compõem o cenário noturno andresiano como a lua, a quebra do silêncio noturno pelo murmurar do vento a passear por entre as folhagens, um mundo vegetal paradisíaco, representado principalmente na imagem do jardim:

Mais uma vez encontro a tua face,

Ó minha noite que eu julguei perdida.

Mistério das luzes e das sombras

Sobre os caminhos de areia,

Rios de palidez em que escorre

Sobre os campos a luz cheia,

Ansioso subir de cada voz,

Que a noite clara se desfaz e morre.

\footnotetext{
${ }^{123}$ ANDRESEN, Sophia de Mello Breyner. Livro sexto. Lisboa: Caminho, 2003, p. 53.

${ }^{124}$ A imagem do polvo será estudada mais intensamente no próximo capítulo.
} 
Secreto, extasiado murmurar

De mil gestos entre a folhagem,

Tristeza das cigarras a cantar.

Ó minha noite, em cada imagem

Reconheço e adoro a tua face,

Tão exaltadamente desejada,

Tão exaltadamente encontrada,

Que a vida há-de passar, sem que ela passe,

Do fundo dos meus olhos onde está gravada. ${ }^{125}$

A primeira estrofe inicia-se com a expressão "Mais uma vez", que traz a ideia de repetição, na configuração binária das estrofes, remetendo ao movimento circular da noite. A noite dentro do poema é uma personagem, possui uma face. O uso do pronome possessivo "minha", na invocação do início do segundo verso, garante a esta personagem um caráter muito íntimo e pessoal, portanto, o eu lírico não irá falar de uma noite qualquer, mas da sua noite.

Nas quatro estrofes seguintes, temos os elementos que compõem a face (cenário) dessa noite descrita pelo eu lírico: a lua, o jogo de luzes e sombras, o rio, os campos, as folhagens, as cigarras. Esses elementos apontam para dois tipos de movimento: o horizontal, nas imagens dos caminhos de areia, dos rios e dos campos, em que a vastidão da imagem proporciona uma essência material, e o vertical, marcado com o cair da noite, principalmente no movimento instaurado pelo subir de cada voz, que no encontro com a noite clara se desfaz e morre. A presença do verbo "subir" pode indicar, na sua transversalidade, um encontro do eu lírico com a solidão na busca de um lugar puro e verdadeiro, uma busca da essência divina. São descrições que dão vazão a sentimentos de sublimação e exaltação: o aparecer da lua cheia, o silêncio, o balançar das folhagens, a profundidade e importância com o uso dos adjetivos, "ansioso" e "extasiado".

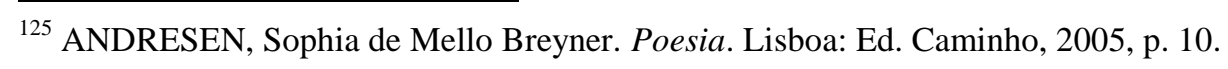


Temos, depois, o verso "Tristeza das cigarras a cantar", que pode ser considerado como uma linha divisória, separando o poema em dois momentos: no primeiro, ocorre a descrição da noite e os seus elementos (plano material); no segundo, temos a descrição dos sentimentos relacionados à noite (plano subjetivo). O adjetivo "tristeza" que qualifica o canto das cigarras reafirma o tom melancólico e nostálgico que envolve o ambiente noturno do poema. Mas, ao mesmo tempo, é um universo extremamente vivo e sonoro: vozes, murmúrios das folhagens, o canto das cigarras.

O último conjunto de versos do poema inicia-se novamente com a saudação, "Ó minha noite $[\ldots]$ "., o que reafirma o seu caráter pessoal e particular. $\mathrm{O}$ aprofundamento neste ambiente noturno acolhedor, pelo eu lírico, é intensamente desejado e exaltado, porque é o reino das sombras que possibilita a configuração do seu mundo, não a luz do dia. Todas as imagens da natureza, inundadas pela noite que vão surgindo conforme prossegue o poema, tentam resgatar uma dimensão primeira, arcaica, primitiva, que somente pode ser restaurada se houver harmonia entre o humano e a natureza. Rompe-se qualquer fronteira, qualquer limite entre o sujeito e o objeto: “Que a vida há-de-passar, sem que ela passe / do fundo dos meus olhos onde está gravada”.

No poema que agora analisaremos, "Noites Sem Nome" presente no livro Poesia, de 1944, há vários pontos que podemos ressaltar sobre o trabalho poético na construção do poema:

Noites sem nome, do tempo desligadas,

Solidão mais pura do que o fogo e a água

Silêncio altíssimo e brilhante.

As imagens vivem e vão cantando libertadas

E no secreto murmurar de cada instante

Colhi a absolvição de toda a mágoa. ${ }^{126}$

${ }^{126}$ ANDRESEN, Sophia de Mello Breyner. Poesia. Lisboa: Caminho, 2005, p. 23. 
O primeiro ponto a ser analisado é a contradição existente entre o título do poema, "Noites Sem Nome", e o fato de que todos os versos que compõem a primeira estrofe não possuem verbos; são constituídos apenas de frases nominais, ou seja, por substantivos e adjetivos, fato que aponta também para uma materialidade.

Através da descrição feita pelo eu lírico sabemos que não estamos diante de uma noite qualquer, mas da personificação da Noite primordial. A primeira estrofe do poema poderia ser uma espécie de evocação a esta noite. Intensamente potencializadas, essas "noites sem nomes" tornam-se, assim como o poema, espaço ilimitado da imaginação e do sonho.

Outro ponto importante é que a ausência de verbos indica a falta de ação e, portanto, não há a presença limitadora do tempo, fato que podemos confirmar no primeiro verso do poema: “[...] do tempo desligadas".

Trata-se de uma noite atemporal, anterior à própria noite: é a mística Grande Noite. Nos dois últimos versos, temos os outros dois elementos fundamentais que formam a imagem destas noites sem nome: a solidão e o silêncio. Há certa intencionalidade no excesso da descrição desses elementos, deixando clara a intenção de torná-los mais expressivos: a solidão é mais pura do que dois elementos primordiais do universo, "o fogo e a água" e o silêncio é "altíssimo e brilhante".

Nos três versos que compõem a segunda estrofe, a presença de verbos rompe com a imobilidade e o silêncio: viver, murmurar, cantar. O movimento das imagens e o canto possibilitam a liberdade deste eu lírico transformando toda a mágoa em absolvição.

A imagem do espaço noturno associado ao silêncio e ao murmúrio é muito comum em alguns poemas de Sophia Andresen. Octávio Paz lembra que "a poesia nasce no silêncio e no 
balbuciamento, no não poder dizer, mas aspira irresistivelmente à recuperação da linguagem como uma realidade total."127

A imagem da noite escura, presente em alguns poemas andresianos, pode ser entendida como uma metáfora da morte (Thânatos), pois a esta se assemelha em vários pontos: a noite priva-nos da luz, assim como a morte, jogando-nos e todas as coisas para dentro da obscuridade. A falta de visibilidade nos incute o medo do desconhecido, assim como o desconhecimento do que virá depois do limiar da morte. O silêncio que, aos poucos, impõe-se faz com que nossa imaginação mergulhe em um universo de imagens outras, de um mundo fantasmagórico, repleto de sons e murmúrios medonhos. Também a sensação de infinito, presente na escuridão, cria devido à impossibilidade de darmos conta ou absorver sua totalidade, o vazio que a morte simboliza.

No poema "Noite das coisas", presente no livro Poesia, de 1944, o eu lírico aproveita o tema da noite e todas as sensações fortes que ela provoca para falar do ato de escrever, cuja aura de instabilidade instaura sentimentos díspares de paz e tensão por "sobre as linhas", ou melhor, nas suas entrelinhas:

\footnotetext{
Noite das coisas, terror e medo

$\mathrm{Na}$ aparente paz dispersa

Sobre as linhas nas paredes caiadas,

Gestos e murmúrios de conversa

No mundo estranho do arvoredo. ${ }^{128}$
}

No poema, há a metáfora entre "as linhas nas paredes caiadas" significando possivelmente as folhas de um caderno no qual o poeta escreve. Esse escrever nunca é tranquilo, tanto que a "paz" é "aparente" e "dispersa", implicando a tensão que o ato comporta. O espaço noturno colabora para que haja também "terror e medo".

\footnotetext{
${ }^{127}$ PAZ, Octavio. Signos em rotação, Tradução de Sebastião Uchoa Leite. São Paulo: Perspectiva, 1996, p.120.

${ }^{128}$ ANDRESEN, Sophia de Mello Breyner. Poesia. Lisboa: Caminho, 2005, p. 21.
} 
A escuridão da noite, ao diminuir o campo visual, acaba por interferir nas formas das coisas. As intensas e contraditórias sensações que surgem, alimentam a imaginação. É no período noturno que os sentidos intensificam-se, alertas, permitindo ver e ouvir um mundo sombrio. Assim as árvores convertem-se em imagens aterradoras, ganhando formas e contornos assustadores. A personificação destas em estranhos seres espectrais e fantasmagóricos quebram a "paz aparente” do período noturno.

A cor branca e a escuridão da noite formam um par de contrários que encontramos em alguns poemas da obra de Sophia Andresen. Como no poema acima, às vezes marca a metáfora que ocorre entre as paredes brancas da casa, do quarto e as folhas de um caderno, que envolve o próprio ato de escrever, de criar por parte do eu lírico. Ainda podemos pensar em outra possibilidade para a cor branca, como representação da morte e citamos os seguintes versos: "Depois da cinza morta destes dias, / quando o vazio branco destas noites" $(\text { Coral })^{129}$ e "As paredes são brancas e suam de terror / a Sombra devagar suga o meu sangue" (No tempo dividido). ${ }^{130}$

O branco abarca inúmeros sentidos: pode simbolizar a paz, o absoluto, a representação do dia, da vida, do lado positivo das coisas. Porém, também está relacionada com a morte, na medida em que simboliza a falta da vida: "seu aspecto nefasto, o branco lívido contrapõe-se ao vermelho"131 que tem como referência o sangue/ vida. Talvez a representação imagética mais propícia para entendermos este pensamento seja a personagem da Morte do filme Sétimo Selo, do diretor Ingmar Bergman: é marcante o contraste entre o preto das suas vestimentas e o rosto branco, lívido, sem vida.

\footnotetext{
${ }^{129}$ ANDRESEN, Sophia de Mello Breyner. Coral. Lisboa: Caminho, 2005, p. 11.

${ }^{130}$ Idem. No tempo dividido. Lisboa: Caminho, 2005, p. 11.

${ }^{131}$ CHEV ALIER, Jean e Alain GHEERBRANT. Dicionário de símbolos. Tradução de Vera da Costa e Silva. Rio de Janeiro: José Olympio, 2008, p. 142.
} 
Com seus variados elementos simbólicos, o jardim, confere ao poema uma multiplicidade de linguagens, e simbolismo da morte é uma delas. Do mesmo modo que passa a ser uma expansão do espaço interior da casa para o seu exterior, para o seu entorno, na poesia andresiana este pode assumir a função de simbolizar uma expansão, um "ir além", que a morte também contém: "A hora da partida soa quando / Escurece o jardim e o vento passa $[\ldots]^{, 132}$.

A atmosfera de serenidade e paz que os jardins naturalmente inspiram, em alguns poemas, é quebrada, passando a adotar uma aura densa, inquieta e tensa, como nos mostra o poema “O Jardim Perdido" do livro Poesia, de 1944:

\footnotetext{
Jardim em flor, jardim de impossessão, Transbordante de imagens mas informe, Em ti se dissolveu o mundo enorme, Carregado de amor e solidão

A verdura das árvores ardia, O vermelho das rosas transbordava, Alucinado cada ser subia Num tumulto em que tudo germinava.

A luz trazia em si a agitação De paraísos, de deuses e de infernos, E os instantes em ti eram eternos De possibilidade e suspensão.

Mas cada gesto em ti se quebrou, denso Dum gesto mais profundo em si contido Pois trazias em ti sempre suspenso Outro jardim possível e perdido. ${ }^{133}$
}

A primeira leitura que podemos fazer do poema "O Jardim Perdido" é que ele está imerso em um universo caótico. Podemos apontar uma série de elementos contrários que convivem no espaço do poema e que contribuem para esta sensação de desordem.

No primeiro verso, temos a imagem de um "jardim em flor", que nos remete a uma imagem paradisíaca. Porém, a sequência da leitura do mesmo verso faz com que este

\footnotetext{
${ }^{132}$ ANDRESEN, Sophia de Mello Breyner. Poesia. Lisboa: Caminho, 2005, p. 55.

${ }^{133}$ Ibidem, p.41.
} 
pensamento seja interrompido, pois surge um elemento de negação: ele é também um “jardim de impossessão". O segundo verso, "transbordante de imagens mas informe", encontra-se dentro da mesma lógica estabelecida no primeiro verso: há um excesso de coisas (materiais) para logo em seguida, devido a esse mesmo excesso, tudo se transformar em uma massa amorfa. Ele é "carregado de amor", mas também de "solidão".

Dentro desse cenário caótico, a cor vermelha tem uma função fundamental devido a sua intensidade e sua vibração. Ela surge nos primeiro e segundo versos: "A verdura das árvores ardia, / O vermelho das rosas transbordava". Primeiro, opõe-se à cor verde (fria) da vegetação e indica um possível fogo interno; depois, reforça o caráter de excesso através do verbo "transbordava". A atmosfera de caos é confirmada na segunda estrofe pela presença do adjetivo "alucinado" e do substantivo "tumulto". Ainda na segunda estrofe podemos ter a possibilidade de interpretação do terceiro verso da seguinte forma: quando o sujeito lírico diz que "alucinado cada ser subia", podemos entender que estes seres, mesmo em um ambiente tão conturbado e caótico conseguiram a iluminação (no sentido de "subir", de ascender à iluminação). Encontramos no poema um conceito muito antigo, presente no mito grego e em vários outros, de que o mundo ordenado brotou do caos, já que no último verso, "num tumulto em que tudo germinava", confirma esta ideia. Há ainda a possibilidade suspensa, nesses dois últimos versos da segunda estrofe, de pensarmos em algo que perece, morre (presente no subir dos seres) para que possa brotar outra coisa (decorrente do verbo germinar).

O primeiro verso da terceira estrofe traz outro elemento estranho a todo esse mundo de caos: a luz. Geralmente, a imagem da luz comporta uma variedade de significados: iluminação intelectual e espiritual, conhecimento, ordenação do caos, simbolizando a vida. Porém, imersa nesse universo caótico, ela está despida desses atributos, pois traz dentro de si não a ordem, mas a "agitação" que engloba um mundo complexo e de opostos entre si 
conforme indica a presença da palavra "infernos" no último verso: "de paraísos, de deuses e de infernos". Os “instantes" são "eternos / de possibilidade e suspensão", ou seja: apesar do caráter de "eternos", não possuem a concretude de uma certeza, pois são apenas “possibilidades e suspensão".

Um pensamento muito comum na obra andresiana é o da unidade entre as coisas presentes na metáfora do fio inteiriço que as une. Na quarta estrofe, essa ideia está comprometida, rompida no seu primeiro verso: "mas cada gesto em ti se quebrou, denso". Este também reforça o movimento de fragmentação que vem se estendendo no jogo de contrários do poema.

No último verso, "Outro jardim possível e perdido”, persiste uma mensagem negativa. O movimento de eterno retorno não permite a reconstrução ou a posse de um jardim paradisíaco visto que, como o próprio eu lírico indica, primeiro esse jardim é apenas “possível”, e a possibilidade não é algo concreto; depois, está "perdido".

Podemos dividir o poema em duas metades: a primeira possui uma conotação mais positiva e concreta, de todo um mundo material de coisas, seres, "deuses", "luz", "paraísos" e vegetação. Na segunda, temos os elementos que germinam desta primeira metade, que são os elementos opostos e negativos: “impossessão", “informe”, “solidão”, “tumulto", "agitação", “infernos". Podemos pensar, então, nos dois últimos versos do poema: "pois trazia em ti sempre suspenso / outro jardim possível e perdido”. Ou seja, estamos diante de um poema que exprime um sentimento extremamente negativo, desolador. Todas as coisas possuem duas forças internas: uma positiva, que as impulsiona para a luz, e outra negativa, com um poder destruidor, que implode tudo o que foi erguido antes, impondo a fragmentação e a "suspensão". Não existe nada que se sustente, a não ser o próprio movimento de fragmentação. 
O poema "O jardim e a noite", do livro Poesia, de 1944, é um exemplo de quando a magia da palavra não consegue superar o abismo que circunda todas as coisas. Persiste também uma atmosfera de "desencanto" e de tensão.

É composto de oito estrofes que não possuem um número regular de versos. O tema do encantamento está presente e as rimas servem para marcação de ritmo que geralmente as palavras encantadas possuem. Passemos ao poema:

\author{
Atravessei o jardim solitário e sem lua, \\ Correndo ao vento pelos caminhos fora, \\ Para tentar como outrora \\ Unir a minha alma à tua \\ Ó grande noite solitária e sonhadora $[\ldots]^{134}$
}

Os primeiros versos contêm imagens comuns a outros poemas de Sophia Andresen: “o jardim solitário e sem lua", o "vento" que anima as coisas em seu trajeto e a "grande noite com sua aura de solidão e de sonhos.

A primeira estrofe é marcada pelo adjetivo "solitária", que qualifica o jardim, a noite e também, por dedução, podemos imaginar que qualifique o eu lírico. Assim, temos um cenário marcado pela solidão e vazio que se faz obrigatório para que o sujeito lírico, na sua empreitada de união com a "grande noite", consiga realizar-se. O advérbio “outrora”, presente no terceiro verso, ainda indica que esta não é uma experiência nova, que a situação que se desenrola no decorrer do poema já aconteceu em algum momento no passado.

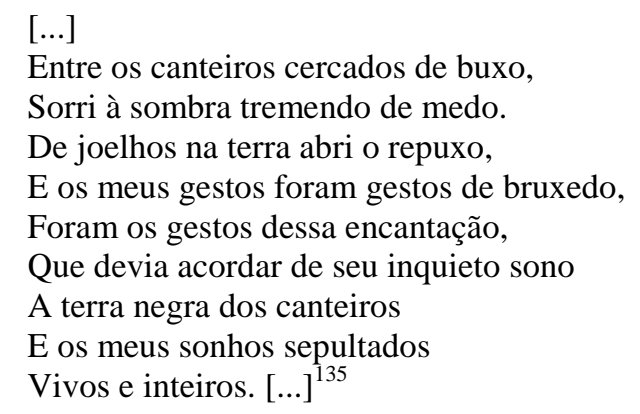

${ }_{134}^{134}$ ANDRESEN, Sophia de Mello Breyner. Poesia. Lisboa: Ed. Caminho, 2005, p. 15.

${ }^{135}$ Ibidem, p. 15. 
As palavras "bruxedo" e "encantação" na segunda estrofe são fundamentais na lógica do poema. A presença destas traz para dentro do poema a ideia do poder mágico da palavra poética. É ela que possibilitará que "os sonhos sepultados / vivos e inteiros" acordem "de seu inquieto sono". Há uma atmosfera tensa presente neste cerimonial, que faz, ao mesmo tempo, com que o sujeito trema de medo e sorria. As palavras "sono" e "sonhos" são elos que traçam mais um ponto em comum com a "grande noite" que também é "sonhadora", criando assim certa aproximação entre sujeito e objeto.

A terceira estrofe do poema é marcada pelo peso do silêncio, do calar que a linguagem não consegue romper:

$[\ldots]$

Mas sob o peso dos narcisos floridos

Calou-se a terra,

E sob o peso dos frutos ressequidos

Do presente

Calaram-se os meus sonhos perdidos. [... $]^{136}$

O poema é marcado pelo desejo de que a linguagem poética consiga concretizar a mágica aliança entre o sujeito e a noite. Desse desejo intenso decorre uma expectativa tensa. Ao falar sobre a tensão presente em alguns poemas de Sophia Andresen, Maria João Borges diz que esta surge em consequência da "entrega sem medida" por parte do sujeito lírico:

Há uma expectativa, ou tensão (grifo do autor), na obra de Sophia, que talvez nem a consagração apolínea, nem a vertigem dionisíaca, nem, porventura, a redenção anunciada pela cruz poderão explicar. Essa tensão provém de uma entrega sem medida a uma expectativa que, de tão absoluta, é relançada após cada encontro (que já vimos consumar-se num momento epifânico), mas que alterna com o seu duplo, a experiência agônica da separação e duma incompletude, por vezes pranteada como irremissível. A expectativa que permanece como tal decorre do que se julgou outorgado por uma promessa (grifo do autor), um contrato cujos termos não são porventura nunca explicitados, mas que é a base do querer do sujeito, o fundamento do desejo que o orienta e da sua sede de absoluto. ${ }^{137}$

\footnotetext{
${ }^{136}$ ANDRESEN, Sophia de Mello Breyner. Poesia. Lisboa: Caminho, 2005, p. 15.

${ }^{137}$ BORGES, Maria João. Em torno do conceito de poesia pura, Cinatti, Sophia e Eugênio de Andrade. Lisboa: Faculdade Letras da Universidade de Lisboa, 1996, p. 315.
} 
Cria-se um cenário estéril, desolado, cuja angústia, nas duas próximas estrofes é gerada pela impossibilidade de superar o profundo abismo vivido pelo eu lírico na grande noite solitária e pura:

\author{
$[\ldots]$ \\ Murmurei as palavras em que outrora \\ Para mim sempre existia \\ O gesto dum impulso. \\ Palavras que eu despi da sua literatura, \\ Para lhes dar sua forma primitiva e pura, \\ De fórmulas de magia. $[\ldots]^{138}$
}

Segundo Octávio Paz, a palavra é distinta da realidade que nomeia, porque o abismo existente entre o homem e seu ser interno é imenso, fato que acaba intervindo na consciência de si mesmo:

\begin{abstract}
A palavra é uma ponte através da qual o homem tenta superar a distância que o separa da realidade exterior. Mas essa distância faz parte da natureza humana. Para dissolvê-la, o homem deve renunciar a sua humanidade transcendendo as limitações que são impossíveis por sua condição. Daí a poesia contemporânea se movimentar entre dois pólos: de um lado, ela é uma profunda afirmação dos valores mágicos; de outro, uma vocação revolucionária. ${ }^{139}$
\end{abstract}

Nos versos seguintes, o fracasso por parte do eu lírico em superar esta distância do materializa-se e tanto a palavra quanto a noite mantêm impenetrável o segredo:

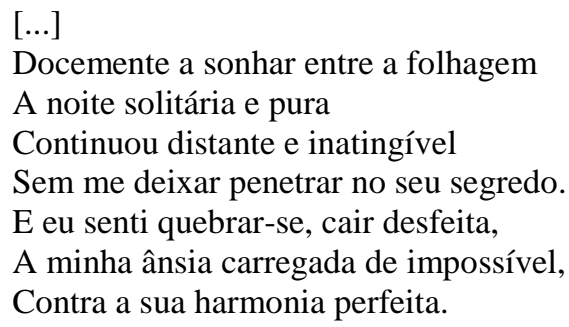

138 ANDRESEN, Sophia de Mello Breyner. Poesia. Lisboa: Caminho, 2005, p. 15-16.

${ }^{139}$ PAZ, Octávio. O arco e a lira. Tradução de Olga Savary. Rio de Janeiro: Nova Fronteira, 1982, p. 43-44. 
Tomei nas minhas mãos a sombra escura

E embalei o silêncio nos meus ombros.

Tudo em minha volta estava vivo

Mas nada pôde acordar dos seus escombros

O meu êxtase perdido. ${ }^{140}$

Apesar do enorme esforço empreendido pelo sujeito, o eu lírico não consegue romper os limites que o impossibilita alcançar a "harmonia perfeita" e resta-lhe apenas aceitar o "silêncio" que seu fracasso lhe impõe.

Para Maurice Blanchot, o ato de Orfeu olhar para Eurídice reflete em si a imprudência contida no desejo, também presente no eterno retorno à perigosa beira do abismo, na busca incansável da Grande Noite, sem nem de longe cogitar a ideia do fracasso. Essa imprudência pertinente ao “desejo que esquece a lei”, Maurice Blanchot chama de inspiração ${ }^{141}$.

Como já foi visto, a presença da Noite, na poesia andresiana, pode ter uma conotação positiva, representar uma experiência mítica de iluminação. Contudo, a noite pode transformar-se em um ambiente obscuro e sombrio, perfeito para ação de seres medonhos, como no poema “Os Pássaros”, do livro Coral, de 1950:

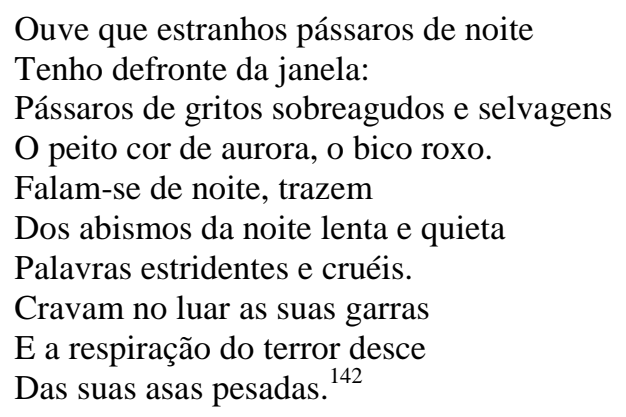

Neste poema, a "noite lenta e quieta" é o espaço sufocante, de tormento, onde o silêncio tão desejado é quebrado pelos "gritos sobreagudos e selvagens" e pelas "palavras

\footnotetext{
${ }^{140}$ ANDRESEN, Sophia de Mello Breyner. Poesia. Lisboa: Caminho, 2005, p. 16.

${ }^{141}$ BLANCHOT, Maurice. O espaço literário. Tradução de Álvaro Cabral. Rio de Janeiro: Rocco, 1987, p.174.

${ }^{142}$ ANDRESEN, Sophia de Mello Breyner. Coral. Lisboa: Caminho, 2005, p. 53.
} 
estridentes e cruéis" dos pássaros ${ }^{143}$ funestos que têm "o peito cor de aurora". Porém, a invocação poética da palavra "aurora" no verso, não possui, como é comum, a significação da esperança de um novo amanhecer, mas sim a marca da desesperança e do terror. Esses pássaros não possuem a leveza natural a eles, as suas assas são "pesadas". O medo traduz-se nas imagens desses pássaros medonhos, cuja aparência representa a crueldade que lhes é pertinente. $\mathrm{O}$ ambiente noturno torna-se então um cenário sinistro, ideal para a proliferação destas feras e bestas, figuras horríveis e medonhas, que incorporam a incerteza, a opressão, o medo, morte que traz a renuncia, como neste poema do livro Mar Novo de 1958:

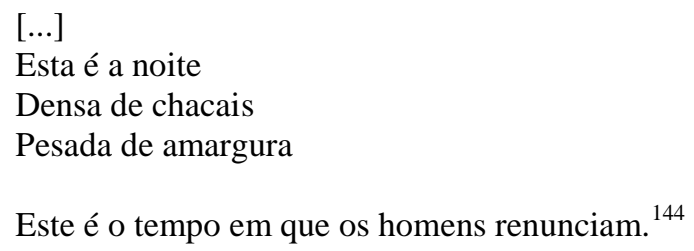

A escuridão sobre todas as coisas impõe a perda da visibilidade, e a visão é um dos sentidos mais importantes no universo poético andresiano. A noite não se transforma em ponte, em porta para outra dimensão, mas acaba por incutir no eu lírico incertezas como o medo do desaparecimento, a profunda dúvida ante o desconhecido.

No livro Mrs. Dalloway, de Virginia Woolf (1925) há uma passagem em que a personagem Rezia, lembrando melancolicamente do tempo em que viveu na Itália, descreve como vê o cair da noite, engolindo tudo e todos. Embora tudo desapareça diante de seus olhos, ela sabe que é apenas um momento. Tudo continua a existir maciça e opressivamente:

Não havia ninguém. Suas palavras dissipavam-se. Como se dissipa um foguete. As chispas, depois de haverem riscado a sua trajetória na noite, somem-se no seio dela, a escuridão retomba, escorre sobre o perfil das casas e das torres; os flancos ermos

\footnotetext{
${ }^{143}$ Em alguns poemas andresianos é comum a presença de figuras de pássaros para representar algo negativo, como o lado trágico da morte. O mito de monstros na forma de pássaros assustadores e terríveis era comum na mitologia grega, como as sereias e as harpias. A figuração dos pássaros, no poema acima, tem uma ligação muito estreita com o mito das harpias, entidades aladas e ferozes, que tinham o corpo de ave e a cabeça de mulher, garras afiadas, que raptavam as crianças e eram capazes de carregar os mortos. Representavam a parte diabólica das energias cósmicas, as provedoras do inferno, graças à morte súbita.

${ }_{144}$ ANDRESEN, Sophia de Mello Breyner. Mar novo. Lisboa: Caminho, 2003, p. 40.
} 
das colinas suavizam-se, desaparecem. Mas, embora hajam desaparecido casas e colinas, a noite está cheia delas; sem cor, sem janelas, existem mais maciçamente, expressando o que a franca luz do dia não pode transmitir - a turbação e a suspensão das coisas aglomeradas na terra; confundidas na treva; privadas do alívio que traz a aurora, quando, molhando as paredes de branco e gris, tocando cada janela, alçando a bruma dos campos, descobrindo as vacas vermelhas que pastam tranquilamente, tudo é mais uma vez revelado aos olhos; tudo existe de novo. - Estou sozinha; estou sozinha! - exclamou, junto à fonte do Regent's Park (olhando para o índio com sua cruz), como talvez à meia-noite, quando todas as lindes se perdem e o campo reverte à sua forma antiga, como o viram os romanos, coberto de névoa, ao desembarcarem, e as colinas não tinham nome e os rios corriam não se sabia para onde - assim era as suas trevas [...]. ${ }^{145}$

A invisibilidade e o desaparecimento são traços comuns entre Noite e Morte na mitologia grega. Sendo assim, essas duas entidades eram responsáveis pelo maior temor que o homem grego antigo poderia sentir: o esquecimento que o desaparecimento no mundo das sombras podia ocasionar. Esse temor Jean-Pierre Vernant explica: "No além, o morto perde as suas feições, os seus traços distintivos; funde-se em uma massa indiferenciada que não reflete o que cada um foi durante a sua vida (...). ${ }^{146}$

O próximo poema a ser analisado, "Os Mortos de Hecate”, encontra-se no livro Dia do mar, de 1947:

Ao nosso lado os mortos em surdina Bebem a exalação da nossa vida, São a sombra segundo os nossos gestos, Sinto-os passar quando leves vêm Alta noite buscar os nossos restos.

Passam nos quartos onde nos deixamos, Envolvem-se nos gestos que traçamos Repetem as palavras que dissemos, E debruçamos sobre o nosso sono Bebem como um leite o nosso sonho.

Intangíveis sem peso e sem contorno Ressurgem no sabor vivo do sangue. Sorriem às imagens que vivemos E choram por nós quando não as vemos, Porque já sabem para aonde vamos ${ }^{147}$

\footnotetext{
${ }^{145}$ WOOLF, Virginia. Mrs. Dalloway. Tradução de Mário Quintana. Rio de Janeiro: Ed. Nova Fronteira, 2006, p. 29.

${ }^{146}$ VERNANT, Jean-Pierre. Mito e pensamento entre os gregos. Tradução de Haiganuc Sarian. São Paulo: Paz e Terra, 2002, p. 431.

${ }^{147}$ ANDRESEN, Sophia de Mello Breyner. Dia do mar. Lisboa: Caminho, 2003, p.80.
} 
Formado por três estrofes, com cinco versos decassílabos, de rimas alternadas, o poema mantém uma estrutura regular. Estes aspectos mais a presença de pontuação contribuem para marcar o ritmo, muito pertinente aos rituais mágicos, aos rituais religiosos, que no poema estão ligados a presença da deusa Hecate. O número três que determina a quantidade das estrofes é consagrado à deusa: "Em suas imagens ela aparecia com três corpos ou três cabeças olhando em três direções, como se estivesse numa encruzilhada"148.

Como deusa lunar, Hecate apresenta dois aspectos opostos: o primeiro, benevolente, é ligado à natureza e a fertilidade, às germinações e aos partos; o segundo, temível e infernal (divindade ctônia), está associado ao mundo dos mortos e às trevas da noite. Seus poderes são temíveis, principalmente à noite. Como a Deusa dos Mortos, preside as aparições de fantasmas.

O poema andresiano é todo trabalhado a partir de duas ideias centrais: a certeza da morte e o ato insistente por parte do eu lírico para que não esqueçamos que ela é uma sombra constante em nossa vida.

No livro O espaço literário ${ }^{149}$, ao lançar a questão "Posso morrer?", Maurice Blanchot discute a contradição que envolve o escritor que, ao mesmo tempo em que deve morrer, esquiva-se da morte:

[...] se os homens em geral não pensam na morte, esquivam-se diante dela, é sem dúvida para fugir-lhe e dissimular-se, mas essa escapatória só é possível porque a própria morte é fuga perpétua perante a morte, porque ela é a profundidade da dissimulação. Assim, dissimular-se em face dela é, de uma certa maneira, dissimular-se nela. ${ }^{150}$

\footnotetext{
${ }^{148}$ KURY, Mário da Gama. Dicionário de Mitologia Grega e Romana. Rio de Janeiro: Jorge Zahar Editor, 1999, p. 172

${ }_{149}$ BLANCHOT. O espaço literário. Tradução de Álvaro Cabral. Rio de Janeiro: Rocco, 1987, p. 92.

${ }^{150}$ Ibidem, p. 92.
} 
A presença do eu lírico é explícita em apenas um único verso, o quarto da primeira estrofe, "Sinto-os passar quando leves vêm". Todos os outros 14 versos do poema encontramse na primeira pessoa do plural. A presença do pronome possessivo "nosso" talvez aponte a intencionalidade do eu lírico de trazer-nos para o espaço do poema, já que a morte também nos é pertinente.

Os versos "Sorriem às imagens que vivemos / E choram por nós quando não os vemos", indicam certa cumplicidade entre os vivos e os mortos. É relevante lembrarmos, porém, que a atmosfera de intimidade não reduz o tom extremamente sombrio e macabro no qual o poema está inserido: assim sendo, também somos, de uma maneira ou de outra, os mortos de Hecate.

A escuridão da "alta noite" propicia a aparição de seres fantasmagóricos e assustadores, que rompem os limites e passam a conviver conosco. Instala-se a convivência de dois mundos diferentes entre si: o dos vivos e o dos mortos. É à noite que, aguçados pela nossa imaginação, costumamos ver e ouvir coisas estranhas que o silêncio noturno intensifica. O medo da noite é ancestral.

A expressão "em surdina" presente do primeiro verso, "Ao nosso lado os mortos em surdina”, indica que não conseguimos perceber a companhia dos mortos, que por serem invisíveis, agem sem que nos demos conta deste fato, assim como a morte.

Com a expressão "em surdina" podemos ainda pensar que o eu lírico qualifica a morte como uma força traiçoeira, que age nas sombras. Não somente isto, mas "a sombra segundo os nossos gestos", ou seja, a morte é a sombra, a nossa sombra.

Os mortos como sombras são "leves", "Intangíveis sem peso e sem contorno". Assim sendo, não podemos defini-los nem senti-los. A hora noturna é a do medo, devido a escuridão, 
o que é desconhecido e assustador revela-se. A noite, ao mesmo tempo silenciosa e misteriosa, é o espaço mágico onde tudo acontece, pois os nossos sentidos intensificam-se, a imaginação é aguçada, a visão e a audição ficam em estado de alerta, passamos a ouvir e ver o lado fantasmagórico que a noite comporta.

Oscar Cesarotto fala da relação antiga entre medo do desconhecido e literatura citando uma fala de H. P. Lovecraft no ensaio "Estética do Medo":

\begin{abstract}
"A emoção mais antiga e mais forte da humanidade é o medo, e o tipo de medo mais antigo e mais poderoso é o medo do desconhecido". Esta é a premissa de Lovecraft, formulada com uma tese, abrindo o texto. O medo como causa; o medo do desconhecido, a causa final. No começo era o medo, noite antes da luz. ${ }^{151}$
\end{abstract}

A escuridão da "alta noite", momento em que os mortos passam efetivamente a agir, é um fator que contribui para o clima de terror que o poema inspira, pois intensifica a qualidade de invisibilidade dos mortos, de tal maneira que rompe com qualquer estabilidade possível, pois nos deixa vulneráveis a eles.

O eu lírico aponta outra diferença fundamental entre o comportamento dos mortos e o nosso, o primeiro é marcado pela ação ativa e forte em contraste com a nossa passividade diante do poder infinito da morte, conforme os seguintes versos: "Bebem a exalação da nossa vida", "Sinto-os passar quando leves vêm / Alta noite buscar os nossos restos", "Bebem como um leite o nosso sonho" e "Ressurgem no sabor vivo do sangue".

O contato com os mortos, na visão do eu lírico, exprime sentimentos de horror e de pavor, pois passivamente, não podemos reagir a eles.

\footnotetext{
${ }^{151}$ LOVECRAFT, H. P. O horror sobrenatural em literatura. Tradução de Celso M. Pacionrnik. São Paulo: Iluminuras, 2008, p. 11.
} 
Vejamos os versos da última estrofe do poema:

$$
\begin{aligned}
& {[\ldots]} \\
& \text { Intangíveis sem peso e sem contorno } \\
& \text { Ressurgem no sabor vivo do sangue. } \\
& \text { Sorriem às imagens que vivemos } \\
& \text { E choram por nós quando não as vemos, } \\
& \text { Porque já sabem para aonde vamos }{ }^{152}
\end{aligned}
$$

Estes possuem alguns elementos que estabelecem diálogo direto com o Canto X, da Odisséia de Homero ${ }^{153}$. Neste canto, Odisseu, aconselhado pela feiticeira Circe, entra em contato com as sombras dos mortos no Hades, a fim de retornar à Ilha de Ítaca.

No verso, "Intangíveis sem peso e sem contorno", o eu lírico descreve algumas características próprias dos mortos que remetem também a descrição feita por Odisseu dos habitantes do Hades: "[...] as pálidas sombras dos mortos". O verso seguinte, "Ressurgem no sabor vivo do sangue", alude a um fato importantíssimo: Odisseu precisava falar com o eidolon (sombra) do adivinho Tirésias, para que este lhe ensinasse o caminho de volta à Ilha de Ítaca. Para conseguir as informações, a moeda de troca entre Odisseu e Tirésias era o sangue de alguns sacrifícios que o herói levava. Somente depois de beber o sangue, o adivinho revela como o herói grego poderia retornar à sua ilha.

Há ainda outra possibilidade de aproximação entre o quarto verso da última estrofe, "Porque já sabem para aonde vamos" e o adivinho do poema homérico: tanto os mortos no poema andresiano, quanto o eidolon de Tirésias são os únicos que possuem o conhecimento dos caminhos do porvir.

Guardadas as devidas proporções, ainda podemos estabelecer outra relação entre a descrição feitas dos mortos com a figura mítica da Gorgó. No poema andresiano, os mortos são descritos como seres noturnos terríveis que bebem nossas forças e os nossos sonhos,

\footnotetext{
${ }^{152}$ ANDRESEN, Sophia de Mello Breyner. Dia do mar. Lisboa: Caminho, 2003, p.80.

${ }^{153}$ HOMERO, Odisseia. Tradução de Carlos Alberto Nunes. Rio de Janeiro: Ediouro, 2004, p. 192.
} 
bebem "a exalação de nossa vida" e que renascem a partir do "sabor vivo" do nosso sangue. Esta é uma característica física da morte, que a partir da eliminação de todos os fluídos líquidos do corpo o transforma em matéria mineral, em pó.

O mito que envolve a figura da Gorgó diz que seu olhar era tão penetrante que petrificava quem fosse visto de frente por ela. É esta qualidade de rigidez e imobilidade da pedra que possibilita o traço de comparação entre os mortos/morte do poema andresiano e o mito das divindades das Gorgós. Jean-Pierre Vernant a descreve como representação do próprio poder da Morte, do qual o homem pode em um momento desviar-se, mas que jamais poderá deixar de encontrar, porque este a traz dentro de si:

Da mesma forma, quando olho Gorgó dentro dos olhos, sou eu quem vejo, ou melhor, o que em mim já é outro: o que está além de mim, não mais em direção ao alto, em direção ao sol da beleza, mas para baixo, para a cegante noite do caos: a morte de frente. ${ }^{154}$

Por todas essas características é natural que o poema andresiano “Os Mortos de Hecate", que tem como motivo a morte, seja marcado pela imagística sombria e fantasmagórica do ambiente noturno, marcado através de expressões como "Alta noite", "nos quartos onde nos deixamos", "nosso sono" e "nosso sonho". Durante a vigília noturna embaraçam-se o mundo interior e exterior e envoltos por imagens e sons assustadores, caóticos, re-codificam e re-organizam o espaço imaginário marcado pela subjetividade, pela experiência do fluir da linguagem poética.

A partir da experiência do sujeito lírico no contato com a noite, configura-se a materialização de vários mundos, onde às vezes a imagem da natureza é marcada pelo excesso, noutros pela privação total desta, mas todos atravessados, em maior ou menor grau, por sentimentos díspares como o espanto, a melancolia, a angústia, o desencanto, a solidão,

\footnotetext{
${ }^{154}$ VERNANT, Jean-Pierre. Entre mito e política. Tradução de Cristina Murachco. São Paulo: Edusp, 2002, p.84.
} 
mas, principalmente, por tudo que representa o desconhecimento que habita na morte, o medo.

Para Octávio Paz, é o horror que interdita a existência, tornando o Universo em abismo, é a falta de ação, de movimento que se estabelece diante de nós, que acaba por engendrar o horror de se estar diante de uma totalidade plena, mas, ao mesmo tempo, inacessível ${ }^{155}$.

Georges Bataille, no livro O Erotismo, disse não acreditar que o homem poderia jogar uma luz sobre as coisas que o assustam antes de dominá-las. Nem que pudesse haver esperança do homem existir em um mundo onde não houvesse mais razão para se ter medo. Acredita que: “... o homem pode ultrapassar o que o assusta, pode encará-lo de frente. Ele escapa por esse preço à estranha falta de conhecimento de si mesmo que até agora o definiu."156

Há, nos poemas andresianos, uma atitude corajosa do sujeito lírico que não desvia o olhar diante da escuridão da noite, do desejo "de ultrapassar o que o assusta" na busca de uma possível unidade entre as coisas, mas principalmente na busca do conhecimento de si mesmo, mesmo que esta atitude seja marcada por uma profunda dor.

Lemos, por fim, os primeiros versos do poema "Floresta", do livro Dia do mar, de 1947:

Entre o terror e a noite caminhei

Não em redor das coisas mas subindo

Através do calor das suas veias

Não em redor das coisas mas morrendo

Transfigurada em tudo quanto amei. ${ }^{157}$

\footnotetext{
${ }^{155}$ PAZ, Octávio, O arco e a Lira, tradução de Olga Savary, Rio de Janero, Ed. Nova Fronteira, 1982, p. 157.

${ }^{156}$ BATAILLE, Georges. O erotismo. Tradução de Antonio Carlos Viana. Porto Alegre: L\&PM Editores, 1987, p. 7.

${ }^{157}$ ANDRESEN, Sophia de Mello Breyner. Dia do mar. Lisboa: Caminho, 2003, p. 64.
} 
Maria João Borges, no texto “A poesia de Sophia: Orientatio, iniciação?”, fala que a poesia de Andresen pode ser definida como uma "límpida aproximação do real" e como “registro de uma 'paixão' [...] marcada pelos vestígios de um padecimento". Os versos acima, de certa maneira, confirmam que o sujeito lírico não se omite diante do cenário aterrorizante e dramático que se abre a sua frente, atitude corajosa diante da noite / morte, impulsionada pela paixão que alimenta a vida, "transfigurada em tudo quanto" amou. Por isso, também assume enfrentar os monstros que povoam as sortes, no mundo grego. 


\section{THÂNATOS: DO MINOTAURO ÀS FÚRIAS}

Nos dois capítulos anteriores, verificamos algumas possibilidades que a figura mítica da Morte, nas suas intrínsecas ligações com as imagens do Tempo, da Memória e da Noite, pode assumir nos poemas andresianos. Neste capítulo, procuraremos analisar como podem ser estabelecidas e o que podem indicar as relações traçadas entre certas figuras míticas (o Minotauro, as Fúrias, a Sibila) e algumas heroínas da tragédia grega com as figuras de Thânatos (Morte).

Em alguns poemas andresianos, a presença de certas imagens míticas, como a do Minotauro, incute no poema forças de conflito muito intensas, que acabam por abalar o "equilíbrio" de um mundo que se quer divino e harmônico. O mesmo acontece quando o eulírico opta por imagens tão profundamente complexas e impetuosas como as Erínias ou a Electra. A lisura do mar rompe-se. Surgem zonas de sombras com uma profusão imensa de ruídos, que invadem a claridade do silêncio.

A verticalidade das formas horizontaliza-se e o perturbador sabe-se dividido pelo tempo e pela morte, tornando-se claro. Afloram, então, o horror, o terror, a violência, o medo, em um processo intenso de catarse para, assim, comungar com divino.

O touro, como representação da impetuosidade e da violência da morte, presente nas ações de vários heróis e heroínas da tragédia grega, como Medeia, Aias, também está inscrito no homem andresiano. Por exemplo, temos a imagem do duplo Minotauro-Homem em Epidauro do livro Geografia, de 1967:

[...] Eis-me vestida de sol e de silêncio. Gritei para destruir o Minotauro e o palácio. Gritei para destruir a sombra azul do Minotauro. Porque ele é insaciável. Ele come dia após dia os anos da nossa vida. Bebe o sacrifício sangrento dos nossos dias. 
Como o sabor do nosso pão a nossa alegria do mar. Pode ser que tome a forma de um polvo como nos vasos de Knossos. Então dirá que é o abismo do mar e a multiplicidade do real. Então dirá que é duplo. Que pode tornar-se pedra com a pedra alga com a alga. Que pode dobrar-se que pode desdobrar-se que os seus braços rodeiam. Que é circular. Mas de súbito verás que é um homem que traz em si a própria violência do toiro. $[\ldots]^{158}$

O sujeito, nesse trecho em prosa, descreve o movimento circular de seguidas e ininterruptas transformações que ocorrem no seu interior. Mas para tal foi necessário, primeiramente, estar coberto de sol e silêncio para que, no jogo de elementos contrários, surgisse o som profundo do grito e a sombra.

Como em um processo catártico, o grito obriga que o monstro saia das sombras e exponha-se na claridade da luz, assumindo a sua verdadeira forma de Minotauro, porque só se pode aniquilar aquilo que contém configuração e que, por isso, pode ser decodificado. $\mathrm{O}$ Minotauro, como representação do duplo, é dono de um poder intenso.

Cabe aqui lembrarmos o mito que Aristófanes conta em O Banquete ${ }^{159}$, de Platão, sobre o terceiro tipo de seres humanos, que eram duplos e que foram engendrados pela lua, pois esta também tem uma qualidade dupla que participa tanto da natureza do sol como da terra.

Esses seres esféricos eram terríveis devido à força e ao vigor que apresentavam. Poderosos ambicionavam escalar o céu e atacar os deuses no Olimpo. Zeus, juntamente com os outros deuses, deliberou que, em vez de exterminá-los por completo, ficando privados dos sacrifícios e dos tributos, principalmente do reconhecimento da grandiosidade e dos feitos dos deuses por parte dos homens, resolveu apenas dividi-los, separando-os em duas partes iguais.

O mito do Minotauro está ligado ao do rei Minos, de Creta, descrito como um homem de muita sabedoria. Ao ter o nome do rei associado ao seu, o Minotauro representaria a dominação da perversidade do rei, sua porção selvagem e monstruosa, em oposição à sua

\footnotetext{
158 ANRESEN, Sophia de Mello Breyner. Geografia. Lisboa: Caminho, 2004, p. 65.

${ }^{159}$ PLATÃO. O banquete. Tradução de Carlos Alberto Nunes. Belém: UFPA, 2001.
} 
sabedoria $^{160}$. Como uma representação dupla, o mito simboliza dois aspectos do homem: uma parte racional, humana e outra que abarca todos os nossos aspectos irracionais e selvagens.

Para Júlia Kristeva, o processo de nomear o sofrimento, exaltando-o, dissecando-o, dividindo-o em componentes menores, é um meio de reabsorver o luto, "de nele se deleitar" ${ }^{\prime 161}$, mas também de ultrapassá-lo. É o que de certa forma acontece ao Minotauro. O sujeito descreve uma série de transformações deste ser duplo/monstruoso, o que resulta em outras formas e outras imagens simbólicas. Este processo confirma ao mesmo tempo, a lei irrevogável que se impõe a todas as coisas do mundo: a lei da mutação, da transitoriedade. Ao fazê-lo, tenta decifrá-lo antes que o monstro o devore, pela necessidade que requer de conhecimento e porquê:

[...] toda revelação e todo auto-conhecimento passam necessariamente - e paradoxalmente - pelo real do símbolo enquanto traçado centrífugo do sujeito no seu próprio ato de ruptura e de constante tentativa de apreensão da significação enquanto tal. ${ }^{162}$

O Minotauro assume a forma insaciável do Tempo (imagem abstrata), monstro terrível que come "os anos de nossa vida", bebe o "sacrifício sangrento dos nossos dias", da "nossa alegria do mar". O Minotauro / Tempo transforma-se agora em um "um polvo"163 que está inscrito em um "vaso de Knossos”. Este, segundo o eu-lírico, é “duplo” e o é na relação que estabelece entre os contrários: a representação abstrata do infernal (medo da morte) e a materialidade na consistência do vaso.

Um estudo primeiro da imagem do polvo, indica, segundo o Dicionário de símbolos, que sendo um animal disforme e tentacular (na realidade, braços), é uma representação dos

\footnotetext{
${ }^{160}$ BRANDÃO, Junito de Souza. Mitologia grega. Vol. III. Petrópolis: Vozes, 2007, p. 160.

${ }^{161}$ KRISTEVA, Júlia. Sol negro: depressão e melancolia. Tradução de Carlota Gomes. Rio de Janeiro: Rocco, 1989, p.95.

${ }^{162}$ ALMEIDA, Rogério Miranda de. Eros e Tanatos: a vida, a morte, o desejo. São Paulo: Edições Loyola, 2007, p. 136.

${ }^{163}$ Verificar Anexo - C
} 
monstros que simbolizam os espíritos infernais, e até o próprio inferno ${ }^{164}$. Seguindo esta linha de pensamento, o sujeito, ao lhe conferir a imagem terrível da escuridão do "abismo do mar", mantém a característica fantasmagórica e infernal que a imagem do polvo-monstro comporta na sua relação com a morte.

O fato de estar inscrito nos "vasos de Knossos" confere ao polvo uma nova qualidade: "a multiplicação do real", contida tanto nos movimentos que os braços produzem, quanto na infinita possibilidade de reprodução dos vasos. Há ainda a capacidade de camuflagem do polvo, de ser outro sendo o mesmo, o que o torna assustador, com seus olhos grandes, descomunal e pavoroso, como um olhar de morte.

Este também representa a crença de conter o segredo das metamorfoses ${ }^{165}$. Assim, no bailar do polvo com seus "braços que rodeiam”, movimento circular, agora já é um homem (talvez o Homem Vitruviano de Leonardo Da Vinci) ${ }^{166}$.

Ao completar o processo cíclico o homem "traz em si próprio a violência do toiro", que remete novamente à imagem inicial da duplicidade do homem/touro (Minotauro), unidos pela violência que ambos carregam: "Mas de súbito verás que é um homem que traz em si próprio a violência do toiro." Temos então a impetuosidade, a aniquilação sem limites da violência ${ }^{167}$, a suprema violência que é a interrupção da vida.

Para Mauro Maldonato, ao projetarmos todos esses símbolos assombrosos, incompreensíveis e violentos, estamos entrando em contato com o horror que a interrupção da morte significa:

\footnotetext{
${ }^{164}$ CHEVALIER, Jean; GHEERBRANT, Alain. Dicionário de símbolos. Tradução de Vera da Costa e Silva. Rio de Janeiro: José Olympio, 2008, p.728.

165 Ibidem, p. 932.

166 O Homem Vitruviano de Leonardo Da Vinci de 1490 o desenho elabora a noção de respeito da divina proporção através do raciocínio matemático, sendo um modelo ideal para todos os seres humanos. $\mathrm{O}$ corpo, humano com seus braços e pernas estendidos, se ajustava perfeitamente ao círculo e ao quadrado. (http://www.infoescola.com/desenho/o-homem-vitruviano/). Verificar Anexo - D

167 CHEVALIER, Jean; GHEERBRANT, Alain. Dicionário de símbolos. Tradução de Vera da Costa e Silva. Rio de Janeiro: José Olympio, 2008, p.890.
} 
Aqui tocamos de perto a importância do símbolo que, ocultando e revelando a um só tempo, restitui à morte sua dimensão psicológica. Para Herzog, ali onde a morte é assumida como pulsão, o símbolo é que a revela. Temos, portanto, necessidade da morte $^{168}$.

Todavia, a morte ainda continua sem resposta, é uma incógnita, "porque é um convite perene à indagação."169

Maria João Borges diz que, em Sophia, tudo decorre da relação que se institui com o real, que a sua poesia é o registro de uma "paixão" marcada pelos vestígios de um padecimento, pois o caminho do homem, sendo um processo de conhecimento no contato com as coisas, resulta em uma soma de deslumbramento e perplexidade:

[...] a orientação, determinada pelo desejo ou paixão que inflama o sujeito, não elimina nem o enigma, nem o aleatório, de uma caminhada que se revela destino envolto pelo mistério. 170

Elementos como o vazio, zonas de sombra, de opacidade, de incomunicabilidade, o excesso, a desmesura, o horror, na sua ambiguidade, contêm um poder de atração infinito nesta poesia. É essa fascinação que faz com que Édipo grite, "Esse horror é meu"171, e que no poema andresiano "Signo", o eu-lírico proclame, "Meu signo é o da morte"172. Ambos não renegam o horror e em um sinal de força colocam-se de frente a ele, confrontando-se com este. Esta atitude segundo Maurice Blanchot demonstra que:

Até a morte é poder: não é um simples fato que vai me acontecer, acontecimento objetivo e constatável. Aí vai cessar meu poder ser, aí não poderei mais estar. Mas, desta não possibilidade, a morte, na medida em que ela me pertence e somente a mim, visto que ninguém pode morrer a minha morte por mim e em meu lugar, este meu futuro iminente, esta relação a mim sempre aberta até meu fim, realiza ainda um poder. Morrendo posso ainda morrer, eis nosso signo de homem. ${ }^{173}$

\footnotetext{
${ }^{168}$ MALDONATO, Mauro. A subversão do ser. Tradução de Luciano Loprete. São Paulo: Peirópolis, 2001, p.144. ${ }^{169}$ Ibidem, p. 148 .

${ }^{170}$ BORGES, Maria João. Em torno do conceito de poesia pura. Cinatti, Sophia e Eugênio de Andrade. Lisboa: Faculdade de Letras da Universidade de Lisboa, 1996, p.258.

${ }^{171}$ SÓFOCLES. Édipo Rei. Tradução de Trajano Vieira. São Paulo: Perspectiva, 2009, p.170.

${ }^{172}$ ANDRESEN, Sophia de Mello Breyner. Geografia. Lisboa: Caminho, 2004, p. 40.

${ }^{173}$ BLANCHOT, Maurice. A conversa infinita. Tradução de Aurélio Guerra Neto. São Paulo: Escuta, 2001 , p.85.
} 
$\mathrm{Na}$ entrevista concedida a Virgílio de Lemos, para a revista Ler - Livros \& Leitores, a poeta Sophia Andresen confirma que sua poesia comporta forças de destruição:

Sim, há certas forças de destruição muito fortes na minha poesia. O que é sombrio é muito sombrio. Foi o Joaquim Vital, em Paris, que mo disse e corresponde à verdade. Há coisas extremamente nocturnas e sombrias em poemas, como por exemplo, 'As Sibilas' ou numa história como 'A viagem'. Mas eu tenho imenso medo das coisas sombrias. ${ }^{174}$

Essas "forças de destruição", "o sombrio que é muito sombrio", as "coisas extremamente nocturnas", que atravessam a poesia andresiana, apresentam-se na relação que existe entre o Homem, a Natureza e o Divino. E estas constituem energias muito superiores que ultrapassam o homem. Daí deve advir o temor de se estar lidando com algo tão poderoso.

Para o crítico literário Eduardo Prado Coelho, em “A Palavra sobre a Palavra”, o excesso na poesia de Sophia Andresen indica um esvaziamento, uma ausência, pois é justamente a "intensidade excessiva da presença das coisas que aponta o fogo devorador da ausência que as ilumina", resultando em algo que ele denomina de "teologia negativa". ${ }^{175}$

O poema "As Sibilas" do livro Coral de 1950, contém versos que apresentam uma atmosfera devastadora, de forças intensamente aniquiladoras:

\author{
Sibilas no interior dos antros hirtos \\ Totalmente sem amor e cegas, \\ Alimentando o vazio como um fogo \\ Enquanto a sombra dissolve a noite e o dia \\ $\mathrm{Na}$ mesma luz de horror desencarnada. \\ Trazer para fora o monstro orvalhado \\ Das noites interiores, o suor \\ Das forças amarradas a si mesmas \\ Quando as palavras batem contra os muros \\ Em grandes vôos cegos de aves presas \\ E agudamente o horror de ter as asas \\ Soa como um relógio no vazio. ${ }^{176}$
}

\footnotetext{
${ }^{174}$ LEMOS, Virgílio de. "Sophia: 'Há forças de destruição na minha poesia', In: Ler, Livros \& Leitores, 1989, n.7, p.22.

${ }^{175}$ COELHO, Eduardo Prado. "O real, a aliança e o excesso na poesia de Sophia de Mello Breyner Andresen", In: A palavra sobre a palavra. Porto: Portucalense, 1972, p. 231.

${ }^{176}$ ANDRESEN, Sophia de Mello Breyner. Coral. Lisboa: Caminho, 2005, p. 36.
} 
Sibila (Pitnosia, em grego), segundo o Dicionário de mitologia grega e romana, de Mário da Gama Kury ${ }^{177}$, era um dos nomes dados às sacerdotisas incumbidas de proferir os oráculos de Apolo. Ela teria sido a primeira sacerdotisa dotada de dons proféticos, motivo pelo qual todas as seguintes passaram a ter essa denominação. Elas viviam geralmente dentro de grutas, talvez porque, como nos lembra Maurice Blanchot, "falar é originalmente romper com toda visão e não mais relacionar-se com a claridade (nem com a falta de claridade)". ${ }^{178}$

Há várias fontes do mito, como a Sibila de Cumas. Ela pediu ao Deus Apolo, que a amava, uma vida longa, mas esqueceu-se de pedir para preservar a sua juventude. A cada ano que passava ficava mais velha, seca e diminuía de tamanho. Quando ficou do tamanho de uma cigarra, foi posta em uma gaiola no templo de Apolo em Cumas, como se fosse um pássaro. Quando inquirida pelas crianças sobre seu maior desejo, ela respondia que queria morrer.

A forma do poema não apresenta regularidade na quantidade de versos distribuídos nas duas estrofes que o compõem. Na primeira, temos cinco e na segunda, sete versos. A poeta opta pelos versos livres, sem pontuação. Segundo Octavio Paz, o verso livre contemporâneo faz com que cada verso seja uma imagem, sem que seja necessário suspender a respiração para dizê-los. Por isso, não é raro que a pontuação seja desnecessária: “As vírgulas e os pontos sobram; o poema é um fluxo e refluxo rítmico de palavras". ${ }^{179}$

A imagem das Sibilas, descrita no poema, foi completamente esvaziada da sua função fundamental presente no mito antigo: o poder da palavra na sua ligação com o divino. Ninguém as ouve mais, estão reclusas nas profundezas de um antro escuro, já não podem mais intermediar a comunicação entre os homens e os deuses.

\footnotetext{
${ }^{177}$ KURY, Mário da Gama. Dicionário de mitologia grega e romana. Rio de Janeiro: Jorge Zahar Editor, 1999, p. 356.

${ }^{178}$ BLANCHOT, Maurice. A conversa infinita. Tradução de Aurélio Guerra Neto. São Paulo: Escuta, 2001, p.106.

${ }^{179}$ OCTAVIO, Paz. O arco e a lira. Tradução de Olga Savary. Rio de Janeiro: Nova Fronteira, 1982, p. 87.
} 
Para Eduardo Prado Coelho, no ensaio "O real, a aliança e o excesso na poesia de Sophia de Mello Breyner Andresen", a poesia andresiana "nos conduz a uma espécie de teologia negativa, o 'grande Deus invisível', o Grande Ausente." ${ }^{180}$ É uma poesia cuja uma das razões de ser é a "ausência"

\author{
Em Nome ${ }^{182}$ \\ Em nome da tua ausência \\ Construí com loucura uma grande casa branca \\ $\mathrm{E}$ ao longo das paredes te chorei
}

No poema "As Sibilas", há várias palavras que confirmam o esvaziamento das imagens, uma ausência que a linguagem presentifica nos versos da primeira estrofe: "sem", "vazio", "dissolve", “desencarnada".

Para Maria João Borges, a linguagem na poesia andresiana “se quer 'nome das coisas', mágica convocação do universo visível e invisível que permitirá a experiência da plenitude" ${ }^{\natural 183}$, mas é através da complexidade da ausência, do vazio, da morte, da própria morte da palavra que se edifica na experiência radical vivenciada pelo eu lírico.

No poema, temos, na figura das Sibilas, a suspensão do encantamento que a palavra possui. A perda dessa função acarreta consequências trágicas e terríveis, que configuram imagens inquietantes: Sibilas "totalmente sem amor e cegas"184, ou seja, desprovidas de qualquer possibilidade de visualização, de contato com o divino. Estão impossibilitadas de profetizar qualquer futuro, de trazer aos olhos a construção do devir.

\footnotetext{
${ }^{180}$ COELHO, Eduardo Prado. O real, a aliança e o excesso na poesia de Sophia de Mello Breyner Andresen. In: A Palavra sobre a Palavra. Porto: Portucalense, 1972, p. 231.

${ }^{181}$ A ausência também surge como pilar no primeiro verso da última estrofe do poema "Horizonte Vazio", do livro Dia do mar: "Horizonte vazio, esqueleto do meu sonho". [ANDRESEN, 2003: p. 75].

182 ANDRESEN, Sophia de Mello Breyner. Dual. Lisboa: Caminho, 2004, p. 14.

${ }^{183}$ BORGES, Maria João. Em torno do conceito de poesia pura, Cinatti, Sophia e Eugenio de Andrade. Lisboa: Faculdade de Letras da Universidade de Lisboa, 1996, p. 253.

184 Segundo o Dicionário de símbolos, a cegueira é um símbolo de vidência. (CHEVALIER, Jean; GHEERBRANT, Alain: p. 656).
} 
Essa impossibilidade instaura o vazio que, "como um fogo" alimenta e consome a tudo. É a sombra que "dissolve a noite e o dia", tornando tudo amorfo, até mesmo a luz, pois esta também aparece esvaziada de seu caráter iluminador, “desencarnada", sem cor, sem força, morta: a luz não é.

Todas as coisas antes ausentes e dissolvidas ganham um contorno assombroso na figura do "monstro orvalhado" que surge a partir "das noites interiores", no início da segunda estrofe, decorrente de um esforço intenso da tensão e da angústia que a imagem das "forças amarradas a si mesmas" produz.

A figura do "monstro" configura a ideia de caos, ou seja, de um mundo destituído de ordem e, por isso, incompreensível. Essa atmosfera tensa, vivenciada pelo eu lírico, onde as forças estão "amarradas em si mesmas", abre-se para um cenário, nos quatro últimos versos do poema, onde a impossibilidade da linguagem torna-se mais evidente na figura da "palavra ave presa”.

No poema, há uma linha que une suas duas estrofes, que parte da imagem das Sibilas cegas até a figura das palavras aves presas, que empreendem grandes vôos cegos. A unidade funda-se a partir da impossibilidade da linguagem. Nessa imagem que o poema edificou, há certo traço irônico no não-ser da palavra, que se torna tão inútil quanto a última imagem, do relógio que soa no vazio. A ambiguidade do poema constrói-se a partir da impossibilidade da linguagem: seu não-ser é o sentido de existir do poema.

O fluir de elementos contrários nos versos, como luz/sombra, dia/noite, grandes vôos cegos/ ter as asas, no entanto, engrandecem o esforço angustiante e intenso dos movimentos das palavras-aves para romper o círculo, o muro que as cerceiam. Como nos lembra Blanchot, “escrever é configurar os espíritos, é talvez libertá-los contra nós, mas esse perigo pertence à 
própria essência do poder que liberta." ${ }^{185}$ A palavra, espaço ambíguo e contraditório, carrega internamente o vazio que também habita as imagens, os símbolos que o eu lírico constrói para representar a si e a seu mundo.

Mauro Maldonato entende que o advento da modernidade, em seu processo de desmistificação e esvaziamento metafísico, acabou por trazer o "risco da perda da experiência interna do homem como marca indelével da sua origem de estar no mundo"186 (grifo do autor).

Segundo o pensamento de Mauro Maldonato, durante milênios, o sagrado e todos os elementos que dele participavam estavam cercados por um profundo sentido de mistério, o que estabelecia de uma forma muito contundente a impossibilidade de aproximação, uma linha divisória entre o sagrado e o profano, entre deuses e homens.

O problema é que, em um determinado momento de nossa História, essa linha divisória desapareceu, "aniquilado por uma reppresentatio, uma encenação, que nada tem a compartilhar com a força expressiva do símbolo, de seu originário poder ético-religioso."187 Porém, essa dessacralização não anula a dimensão simbólica que remete a uma nova ligação entre o sagrado e o homem, conferindo-lhe outros significados à existência. Ao tentarmos eliminar esta linha de divisa, o elemento sagrado sempre retorna, mas "numa forma não transcendente e sim imanente, numa forma de violência e do conhecimento da violência". Portanto, "a violência tem uma obscura e inseparável ligação com o sacro."188

Como já vimos anteriormente, há uma tensão sempre presente na obra andresiana, resultante da busca da unidade entre o humano e o divino, mesmo quando o poema nos

\footnotetext{
${ }^{185}$ BLANCHOT, Maurice. O espaço literário. Trad. Álvaro Cabral. Rio de Janeiro: Rocco, 1987, p. 68.

186 MALDONATO, Mauro. A subversão do ser. Trad. Luciano Loprete e Roberta Barni. São Paulo: Peirópolis, 2001, p. 107.

187 Ibidem, p. 174.

188 Ibidem, p. 174.
} 
apresenta um "mar liso". Em algum momento surgem ondulações e turbulências. O que irá variar são os diferentes graus de intensidade. De modo sutil ou contundente, a tensão escapa por entre os vazios que o poema constrói. Há, portanto, um cruzamento de forças atuantes entre a horizontalidade da poesia e a verticalidade profunda de forças intensas e extremas que a habita. Tentaremos localizar essas forças a seguir, através da análise do poema, "Ménades", que se encontra no livro Musas de 1994:

\section{Ménades}

As antigas Fúrias tinham as pupilas vermelhas

Os cabelos eriçados de serpentes

As mãos pesadas a boca sequiosa

De puro sangue a cara tatuada ${ }^{189}$

O poema recupera e ao mesmo tempo une dois mitos antigos, as Fúrias e as Mênades, unidos a partir da força brutal da morte que personificam.

As Mênades, divindades míticas que dão título ao poema eram as mulheres que faziam parte do cortejo do deus Dioniso e que chegavam ao extremo quando tomadas pela mania (loucura). No primeiro verso do poema são as Fúrias que surgem. Elas eram as temíveis divindades vingadoras do sangue, forças muito primitivas, anteriores aos deuses olímpicos. Ambas as figuras configuram-se no âmbito da selvageria e da animalidade. As sensações de assombro e horror que estas imagens suscitam provocam um movimento contrário de repulsa e atração, eu lírico vivencia ao projetar, no espaço do poema, figuras como as Fúrias ou as Mênades.

Ao amalgamar as imagens dos dois mitos, o eu lírico dificulta sua identificação, gerando certo estranhamento. A metamorfose que ocorre no interior do poema faz brotar uma nova imagem, um ser outro que surge contendo um poder muito intenso de significação.

189 ANDRESEN, Sophia de Mello Breyner. Musas. Lisboa: Caminho, 2004, p.24. 
Nos dois primeiros versos, as características que predominam são as das Fúrias (Erínias, para os gregos $)^{190}$. Uma das origens do mito diz que nasceram das gotas de sangue de Cronos que caíram na terra após sua mutilação. Essas divindades terríveis, que perseguiam suas vítimas, clamando por vingança, só saciavam-se com o derramamento de sangue. Tinham também o epíteto de "cadelas furiosas".

No primeiro verso, o eu lírico emprega o adjetivo "vermelhas" para qualificar as pupilas das Fúrias. A cor vermelha remete à origem das Fúrias, ao gosto pelo sangue, ao horror da morte, indiretamente, e à crueza violenta de sua natureza. Essas eram figuras assustadoras, "caçadoras puramente animais" $" 191$.

No segundo verso surge a outra característica fantasmagórica pertinente às Fúrias: “Os seus cabelos eriçados de serpentes”.

A serpente é um mito ctônio antiquíssimo. Representa um sentimento que nos acompanha desde as nossas mais antigas origens - o medo, o pavor da morte, em todas as suas dimensões - não somente como a encarnação da própria morte, mas também da dor física da morte.

O poema acentua o sentimento de horror e pavor que estas criaturas emanam ao usar o adjetivo "eriçadas" para qualificar as serpentes que compõem seu cabelo. Nervosas, estão prontas para o ataque, mas as serpentes também encantam. Seu grande poder de atração, sua sutileza nos movimentos silenciosos, sua estrutura diferente, sua temperatura fria, assim como a morte, causam repulsa e atraem ao mesmo tempo.

\footnotetext{
190 Também são chamadas de Eumênides ("bondosas" ou as "benevolentes", eufemismo usado devido ao medo de atrair para si a sua cólera. Seus nomes são: Aleto, "a que não pára"; Tisífone, "a vingadora do crime"; Megera, “a que inveja” (BRANDÃO, Junito de Souza. Mitologia Grega Vol. I, Petrópolis: Vozes, 1993, p. 207) ${ }^{191}$ VERNANT, Jean-Pierre. Mito e tragédia na Grécia antiga. Trad. Anna Lia A. de Almeida Prado. São Paulo: Perspectiva, 2008, p. 122.
} 
As Fúrias eram criaturas implacáveis. Sinônimo de loucura e morte, elas geravam terror no ser humano e, assim, controlavam a ordem das coisas no mundo através do medo. Delas não se aproximavam nem homem, nem deus, nem fera ${ }^{192}$. Até mesmo Zeus curvava-se diante delas, pois, sendo filhas da Noite, só conheciam “os negros véus, cujo ódio é igualmente negro"193 ("Véus negros" com o sentido de morte).

Podemos verificar através de dois versos do poema "Mênades" (Musa) em relação a dois versos do poema "Fúrias" (Ilhas) que ocorre um esvaziamento do mito:

Ménades

As antigas Fúrias tinham as pupilas vermelhas

Os cabelos eriçados de serpentes $[\ldots]^{194}$

Fúrias

$[\ldots]$

Sem clamor sem olhar

Sem cabelos eriçados e serpentes $[\ldots]^{195}$

Na comparação entre os dois versos que compõem um e outro poema, verificamos que suas características medonhas e assustadoras foram excluídas. Estas encontram-se completamente dessacralizadas. O mito foi esvaziado. Absorvidas pelo mundo, elas não assustam mais ninguém, a não ser o de assimilarem a banalização do mundo.

Na literatura há vários exemplos de "esvaziamento mítico", como aqueles encontrados nas famosas páginas dos romances queirosianos. Em Os Maias, por exemplo, a Megera será uma figura de ironia. Seus traços causadores dos tormentos e sofrimentos foram diluídos e passaram a assimilar certo sarcasmo em relação a sua antiga função:

Ega então, num soberbo alarde de indiferença, cravou o monóculo no palco. O lacaio abalara espavorido, a um repique de sineta; e uma megera azeda, de roupão

\footnotetext{
192 EURÍPEDES. Eumênides. Tradução de JAA Torrano. São Paulo: Iluminuras, 2004, p. 79.

193 Ibidem, p. 79.

194 ANDRESEN, Sophia de Mello Breyner. Musas. Lisboa: Caminho, 2004, p. 24.

195 Idem. Ilhas. Lisboa: Caminho, 2004, p. 70.
} 
verde e touca à banda, rompera de dentro, meneando desesperadamente o leque, ralhando com uma mocinha delambida que batia o tacão, se esganiçava: "Pois hei de amá-lo sempre! Hei de amá-lo sempre! ${ }^{16}$

Retornando ao terceiro verso do poema, as características dessas Fúrias mesclam-se às das Mênades ${ }^{197}$, mulheres também chamadas de Bacantes, que compartilhavam, no frenesi do transe, a mania (loucura) do deus Dioniso.

A descrição que há no terceiro verso (“As mãos pesadas a boca sequiosa”) pode referenciar tanto às Fúrias quanto às Mênades, porém é mais pertinente a estas últimas. Ao dividirmos o verso em duas partes temos, na primeira, "as mãos pesadas". Se pensarmos que as bacantes, quando enlouquecidas, assimilavam o costume de se alimentar dos animais selvagens, devorando até mesmo a carne de seus próprios filhos (como Agave, mãe de Penteu, nas Bacas, drama de Eurípedes), dilacerando a vítima, isso indica que elas tinham uma força extrema nas mãos. Na outra parte do verso, "a boca sequiosa", e no prosseguimento do quarto verso, "de puro sangue a cara tatuada", temos a metamorfose completa das Fúrias em Mênades.

Ao compartilharem o estado de mania exacerbado ${ }^{198}$, as Mênades tornavam-se agentes diretas da morte. Assimilavam o comportamento das feras selvagens, rasgavam, partiam e comiam (omophágia) suas vítimas, saciando sua sede com sangue. Adotavam atitudes que não respeitavam nenhum limite, nenhuma regra, a não ser a loucura. $\mathrm{O}$ comportamento selvagem dessas mulheres simbolizava um retorno a um mundo sem lei, ao caos.

A violência relacionada à imagem das Fúrias é interiorizada, ligada à consciência, "ao remorso, à culpa e à autodestruição daquele que se abandona ao sentimento de um pecado que

\footnotetext{
${ }^{196}$ QUEIRÓZ, Eça. Os Maias. São Paulo: Sá Editores, 2001, p. 447.

197 As primeiras Mênades eram as ninfas que criaram o deus Dioniso [KURY, 1999:260].

198 Apesar das Mênades serem sacerdotisas do deus Dioniso e participarem da loucura beatífica deste, elas não eram profetisas e não tinham o dom da adivinhação, da palavra, como acontecia com as Sibilas.
} 
considera inexpiável."199 A fúria destruidora apodera-se do homem sob múltiplas formas. Jean-Pierre Vernant ${ }^{200}$ explica que, ao falar da força que implode qualquer barreira, em momentos diferentes, na alma do homem e fora dele, esta é uma força de desgraça que engloba, do lado do criminoso, o próprio crime, as motivações psicológicas da falta, a polução que ela traz e o castigo que ela prepara para o culpado. Sua moeda de troca para o delito cometido era a própria morte, através do derramamento do sangue. A força das Fúrias é o terror interno que elas provocam.

Já as Mênades representam o extremo da loucura assassina que habita no homem, a mania cega e a força demoníaca que o ultrapassa, igualando-o às feras. É seu estado mais primitivo, no ato de dilaceramento das vítimas e do profundo prazer que isso provoca.

Há um ponto muito importante que liga esses dois mitos: a quebra de uma interdição, que desencadeia uma resposta na forma de violência. Assim acontece, no caso das Fúrias, com os castigos terríveis e mortais aos crimes cometidos e com o mito das Mênades. Quando há a recusa e a aceitação do deus Dioniso, de Penteu, ocorre a dilaceração e a morte, no rito frenético da selvageria.

Ao reunir essas duas entidades terríveis e fazê-las coexistir ao mesmo tempo no âmbito do poema, Andresen nos remete ao mito do Minotauro, um ser duplo que possuía força extrema. O que está em jogo não é puramente a violência, mas a maneira transgressora como a crueldade se organiza e parece ser necessária e consentida ${ }^{201}$. O desejo é um fator importantíssimo no impulso deste processo:

\footnotetext{
${ }^{199}$ CHEVALIER Jean; GHEERBRANT, Alain. Dicionário de símbolos. Tradução de Vera da Costa e Silva, Rio de Janeiro: José Olympio, 2008, p.376.

${ }^{200}$ VERNANT, Jean-Pierre e NAQUET, Pierre Vidal. Mito e tragédia na Grécia antiga. Tradução de Anna Lia A. de Almeida. São Paulo: Perspectiva, 2008, p. 14.

201 "Há, na natureza e subsiste no homem, um movimento que sempre excede os limites e que nunca pode ser reduzido senão parcialmente. Em geral, não podemos prestar contas desse movimento. Ele é, mesmo por definição, aquilo que nada justificará, mas vivemos sensivelmente sob seu poder [...].” [BATAILLE, 1987:].
} 
Todo desejo está ligado a qualquer coisa determinada que deseja. É este o objeto do desejo que, antes de mais, fez nascer o desejo, estimulou-o, deu-lhe a sua direção. ${ }^{202}$

No longo poema "Marinheiros sem mar", do livro Mar novo, de $1958^{203}$, há muitos indícios da presença das Fúrias (Erínias) vingadoras. É extremamente cruel, marcado pelo excesso e pelo prazer da vingança. Analisaremos alguns versos apenas, onde estes indícios surgem de maneira mais clara e evidente, para que assim possamos compreender como se estabelecem as ações destas vingadoras.

\author{
Longe o marinheiro tem \\ Uma serena praia de mãos puras \\ Mas perdido caminha nas obscuras \\ Ruas da cidade sem piedade \\ Todas as cidades são navios \\ Carregados de cães uivando à lua \\ Carregados de anões e mortos frios. ${ }^{204}$
}

O poema inicia-se com um marinheiro que rompe o interdito ao entregar-se ao doce e transgressor desejo pelas "ruas da cidade sem piedade", virando as costas para a "praia de mãos puras". Portanto, a partir deste verso também sabemos que o castigo da quebra da interdição também será sem piedade: não há perdão. No seu texto, "Sophia, a lírica e a lógica”, Eduardo Prado Coelho lembra quais são os dois grandes inimigos dentro do universo poético andresiano:

Mesmo o leitor desatento descobre que Sophia tem, pelo menos, dois grandes inimigos: o tempo (que é dado como um monstro) e a cidade (que é dada como um polvo). ${ }^{205}$

O marinheiro, em deslumbramento e cegueira, geralmente provocados por um desejo extremo, diz "não" aos mares e aos navios:

\footnotetext{
202 ARENDT, Hannah, O conceito de amor em Santo Agostinho, Tradução de Lisboa: Instituto Piaget, 1997, p.17.

${ }^{203}$ ANDRESEN, Sophia de Mello Breyner. Mar novo. Lisboa: Caminho, 2003, p.14-16.

${ }^{204}$ Ibidem, p. 14.

${ }^{205}$ COELHO, Eduardo Prado. Sophia, a lírica e a lógica. In: Colóquio Letras, n.57-58. Lisboa, 1980, p. 25.
} 


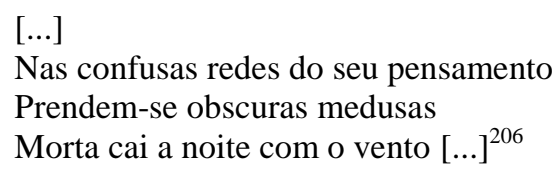

Rejeita a "serena praia de mãos puras", perde-se do "reino puro", ao abraçar escuridão da "cidade sem piedade" e rende-se a ela e aos seus elementos estranhos e bizarros como “anões e mortos frios”, “polvos das sombras", “obscuras medusas”, enredando-se em redes de confusão. No texto "Em torno do conceito de "poesia pura", Maria João Borges diz que a poesia de Sophia Andresen, na aproximação com o real e na sua busca do absoluto, é "o eco jubiloso ou atormentado desse contato", pois:

A existência humana é modelada pela busca do absoluto, matéria de fé (da fé que unifica a obra), cuja voz ou imagem se recolheu e se persegue. O percurso do homem e o conhecimento que dele vai colhendo é soma de deslumbramento e perplexidade; $\left[\ldots . . .^{207}\right.$

Para esse marinheiro, a luz é estabelecida a partir da escuridão de uma noite "morta" e pela violência cega do "vento". Os adjetivos, "morta" e "cega" para qualificar a noite, empregados no poema, estabelecem um cenário marcado pelo absurdo e pela negação.

$[\ldots]$

Vai nos contínuos corredores

Onde os polvos da sombra o estrangulam

$\mathrm{E}$ as luzes como peixes voadores

O alucinam. ${ }^{208}$

Apesar das sensações angustiantes e tensas que os "polvos da sombra" geram, o marinheiro não interrompe seu processo de experiência com tudo que lhe apresentado como o Outro. Este insiste em sua caminhada através dos corredores da cidade, iluminados pelas luzes “como peixes voadores”, o que pode significar que busca a superação de uma situação limite,

\footnotetext{
${ }^{206}$ ANDRESEN, Sophia de Mello Breyner. Mar novo. Lisboa: Caminho, 2003, p. 14.

${ }^{207}$ BORGES, Maria João. Em torno do conceito de poesia pura, Cinatti, Sophia e Eugênio de Andrade. Lisboa: Faculdade de Letras da Universidade de Lisboa, 1996, p. 258.

${ }^{208}$ ANDRESEN, Sophia de Mello Breyner. Mar novo. Lisboa: Caminho, 2003, p. 14.
} 
uma experiência libertadora, que somente um processo catártico pode proporcionar. A vontade, cega ou não, a partir de uma escolha é que determina a sua ação.

O primeiro verso da sétima estrofe, "Porque ele tem um navio mas sem mastros", indica que, ao tomar este caminho, o marinheiro perdeu a verticalidade, a linha que o ligava à "serena praia de mãos puras". O rompimento da aliança, da unidade, com a essa "serena praia" traz-lhe consequências implacáveis. Depois do erro cometido, do caminho desviado, não há mais complacência para arrependimentos, mesmo que se clame ao "vento que há no cais" e que se busque "a luz da madrugada pura". Não é possível limpar as "mãos pesadas de desastres".

Para Georges Bataille, "não existe interdito que não possa ser transgredido"209. Quando se estabelece um, o outro é a sua resposta imediata, ou seja, a transgressão é prescrita ao próprio interdito, e há prazer nos dois extremos, no romper e no punir.

\footnotetext{
Porque ele tem um navio mas sem mastros

Porque o mar secou

Porque o destino apagou

O seu nome dos astros

Porque o seu caminho foi perdido

O seu triunfo vendido

Ele tem as mãos pesadas de desastres

E é em vão que ele se ergue entre os sinais

Buscando a luz da madrugada pura

Chamando pelo vento que há no cais

Nenhum mar lavará o nojo do seu rosto

As imagens são eternas e precisas

Em vão chamará pelo vento

Que a direito corre pelas parias lisas ${ }^{210}$
}

Nas duas estrofes seguintes, o eu-lírico torna as funções das entidades de expiação e de culpa mais claras. É na razão da transgressão cometida e no excesso da violência utilizada como resposta que potencialmente o ser se revela:

\footnotetext{
${ }^{209}$ BATAILLE, George. O Erotismo. Tradução de Antonio Carlos Vieira. Porto Alegre: L \& PM, 1987, p.59.

${ }^{210}$ ANDRESEN, Sophia de Mello Breyner. Mar novo. Lisboa: Caminho, 2003, p. 15.
} 


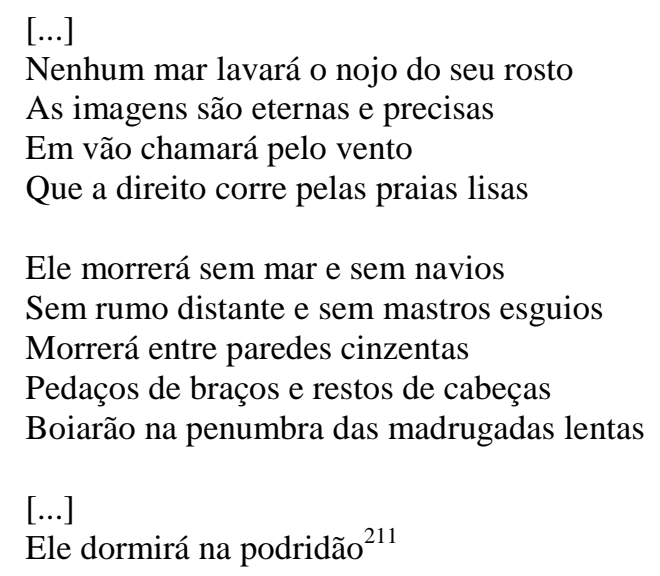

Dessa forma, a reposta aos erros cometidos é terrível. Semeia o medo e o terror. Traz a marca do excesso da punição: é através do terror que estabelece seu controle e seus limites.

O erro e a culpa são marcas indeléveis. Nenhum mar consegue apagar "o nojo do seu rosto" porque, além das imagens serem eternas, possuem o agravante de serem "precisas", ou seja, não há nem sequer a mínima possibilidade de engano na condenação. A privação é marcada de forma contundente pela presença da preposição "sem", que nos dois primeiros versos da nona estrofe repte-se quatro vezes, subtraindo a este marinheiro os elementos fundamentais de seu mundo. Ele morre sozinho, "entre paredes cinzentas". A presença da cor cinza aponta também para uma diluição do ser: esta pode ser considerada como a cor da evasão, da indefinição, da neutralidade, porque é o resultado da mistura entre o branco e o preto, que contém uma gama infinita de tonalidades, não sendo nem um nem outro.

O verso que pontua o comportamento do eu lírico semelhante ao das Mênades é: "Pedaços de braços e restos de cabeças", mostrando a violência do dilaceramento. Não basta a vítima morrer. Girard nos lembra que a morte é a pior violência que se pode sofrer ${ }^{212}$, mas aqui há a necessidade cruenta do excesso da violência e da selvageria nesta morte. Se a vítima é incriminada pelo ato de negar a unidade das coisas, sem piedade, esta terá que sofrer tendo o

\footnotetext{
${ }^{211}$ ANDRESEN, Sophia de Mello Breyner. Mar novo. Lisboa: Caminho, 2003, p. 15.

${ }^{212}$ GIRARD, René. A violência e o sagrado. Tradução de Martha Conceição Gambini. São Paulo: Universidade Estadual Paulista, 1990, p. 319.
} 
seu corpo dividido e "dormirá na podridão" do esquecimento. Há todo um vocabulário comum ao degredo: podridão, nojo.

Em “Sophia, a lírica e a lógica”, Eduardo Prado Coelho diz que há uma forma de morte que é inassimilável para a poesia andresiana, que é a degradação:

Porque a ausência permite que os seres permaneçam presentes na modalidade glorificante do duplo: como deuses ou estátuas (ou poemas). Mas essa forma de ir morrendo que é a degradação instaura um processo de presença da não-presença que é intolerável [...]. ${ }^{213}$

Como observado anteriormente, há duas linhas indissociáveis que atravessam o poema: a interdição e a transgressão. Ambas estão marcadas pelo excesso e por tudo que as excede ou ultrapassa. É na intersecção dessas duas linhas que se dá a violência. A transgressão, ao romper as limitações de um mundo organizado e vigiado pelas interdições, impõe a desordem.

Seguindo os rastros deixados pelas Fúrias em alguns poemas andresianos, deparamonos com "Elsinore", no livro Ilhas, de1989:

\author{
No palácio dos Átridas como em Elsinore \\ Tudo era cavernoso - as paredes \\ Eram grossas o espaço excessivo e sonoro \\ Roucas as vozes da maldição antiga \\ Porém em Micenas o sangue era exposto \\ E corria vermelho como num grande talho \\ Sujando apenas as mãos dos assassinos \\ E a água da banheira - \\ Lá fora o rio a luz \\ Continuavam limpos e transparentes \\ O crime era um corpo estranho circunscrito \\ Não pertencia à natureza das coisas \\ Em Elsinore ao contrário o mal era um veneno \\ Subtil \\ Invadia o ar e a luz - penetrava \\ Os ouvidos as narinas o próprio pensamento - \\ $\mathrm{O}$ amor era impossível e ninguém podia \\ Libertar-se: \\ O inferno vomitava a sua pestilência invadida
}

${ }^{213}$ COELHO, Eduardo Prado. “Sophia, a lírica e a lógica”. In: Colóquio Letras. Lisboa, 1980, n. 57, p. 28. 
As veias e os rios:

No entanto o mal não se via: era apenas

Um leve sabor a podre que fazia parte

Da natureza das coisas. ${ }^{214}$

Esse poema pode ser dividido em dois momentos: no primeiro, temos o drama que envolve o rei Agamêmnon e a rainha Clitemnestra ${ }^{215}$; no segundo, a tragédia de William Shakespeare, Hamlet ${ }^{216}$. Será analisada de uma forma mais detalhada apenas a primeira parte, no intuito de descobrir como os elementos que compõem o drama são acolhidos pelas linhas dos versos.

Assim, se por um lado a poesia de Sophia Andresen tem como uma de suas funções básicas, através da arte, apresentar a dolorosa experiência da precariedade da vida e do aprendizado da morte, por outro lado, sua poesia tem a difícil missão de lembrar que nós também matamos.

O poema não é homogêneo na distribuição dos versos, assim como não há um padrão na métrica, embora contenha mais versos de onze sílabas (hendecassílabo). Os dois primeiros versos traçam um parâmetro de igualdade de como o mal faz parte do ambiente dos palácios nas tragédias Agamêmnon ${ }^{217}$, de Ésquilo (palácio dos Átridas), e Hamlet, o príncipe da Dinamarca $^{218}$ (palácio de Elsinore), de Shakespeare.

As duas primeiras estrofes, a segunda mais especificamente, dialogam com a tragédia Agamêmnon, da trilogia Orestéia, de Ésquilo, a qual se baseia no mito do rei espartano e da rainha Clitemnestra. É uma história marcada pela violência desmedida que atravessa gerações, iniciando com o pai do rei Agamêmnon, Atreu e o ódio que este sentia pelo irmão Tieste, o

\footnotetext{
${ }^{214}$ ANDRESEN, Sophia de Mello Breyner. Ilhas. Lisboa: Caminho, 2004, p. 74.

${ }^{215}$ Verificar Anexo - E.

216 SHAKESPEARE, Willian. Hamlet, o príncipe da Dinamarca. Tradução de F. Carlos de Almeida Cunha Medeiros e Oscar Mendes. São Paulo: Victor Civita, 1981.

${ }^{217}$ ÉSQUILO, Agamêmnon. Tradução de JAA Torrano. São Paulo: Iluminuras. 2004.

${ }^{218}$ SHAKESPEARE, Willian. Hamlet, o príncipe da Dinamarca. Tradução de F. Carlos de Almeida Cunha Medeiros e Oscar Mendes. São Paulo: Victor Civita. 1981.
} 
que leva a crimes e vinganças recíproca, culminando com a morte dos três filhos de Tieste. Este, chegou cortar as crianças mortas em pedaços, para cozinhá-las e servi-las num banquete ao próprio pai.

Agamêmnon era o rei grego mais poderoso na época da guerra de Tróia. Seu destino trágico era uma soma dos crimes e dos erros que cometeu: matou o marido e o filho recém nascido de Clitemnestra, obrigando-a casar-se com ele. Sacrificou a própria filha, Ifigênia, em decorrência de uma falta cometida contra a deusa Ártemis. Assim, é possível entender o sentido da expressão "tudo era cavernoso", no segundo verso, como rancor, mágoa e um ódio tão antigo que, através do tempo, do "espaço excessivo", atormentados e incentivados pelas “roucas vozes da maldição antiga", as Fúrias, sempre sedentas de vingança e terror.

Os dois primeiros versos da segunda estrofe ("Porém em Micenas o sangue era exposto / E corria vermelho como um grande talho") tratam de dois pontos: o primeiro, "sangue exposto", refere-se ao fato de que Clitemnestra, depois de alimentar o desejo de vingança durante muito tempo, consegue realizá-lo, e mata Agamêmnon com um machado, na banheira. Diante do palácio, a rainha assume a autoria do crime: “[...] eis aí Agamêmnon, meu esposo, e morto, façanha desta mão / destra, justo artífice. Assim é isto" ${ }^{219}$. Todos os atos eram assumidos, tudo ficava descoberto.

Com o verso, "E corria vermelho como num grande talho", a poeta sintetiza, de forma brilhante, basicamente dois fatos importantes relacionados à lenda dos Átridas. Primeiro ele remete ao sangue derramado do sacrifício terrível de Ifigênia e do próprio Agamêmnon; segundo também pode referir à cena do tapete púrpura (Clitemnestra, com maestria no uso da

\footnotetext{
${ }^{219}$ SÓFOCLES. Agamêmnon. Tradução de JAA Torrano. São Paulo: Iluminuras, 2004, p.203.
} 
palavra ${ }^{220}$, conseguiu persuadir Agamêmnon a caminhar descalço sobre o tapete, como se fosse um deus, numa atitude de extrema soberba, acarretando para si a ira divina).

A expressão "grande talho" pode aludir também aos ferimentos decorrentes dos golpes de machado desferidos pela rainha. Lembramos de um comentário de Heber Salvador de Lima $^{221}$, quando este diz que a personalidade de Clitemnestra foi trabalhada pelo poeta Ésquilo "a golpes de machado. Ela se esculpe na monstruosidade de seu próprio relato da morte do marido: adúltera e parricida, de machado sangrento nas mãos, gabando-se dos golpes que abateram Agamêmnon, enumerando-os, descrevendo-os com um requinte que raia ao sadismo." 222 Clitemnestra, a assassina de mãos sujas de sangue, é a própria visão monstruosa da morte.

Com os dois versos seguintes, "Sujando apenas as mãos dos assassinos / E a água da banheira", toda a cena da tragédia, resgatada pelo poema, tem sua completude: Egisto (amante de Clitemnestra, filho de Tieste) e a rainha assumem a autoria do crime, não imputando a culpa aos outros.

Com os versos "O crime era um corpo estranho circunscrito / Não pertencia à natureza das coisas", o poema passa a trabalhar a ideia que permeia as três tragédias que formam a Oresteia, de Ésquilo. Os crimes que foram cometidos, de Clitemnestra ${ }^{223}$ e de Orestes, tinham suas motivações nas vinganças de sangue reclamadas pelas sedentas Fúrias. Eram uma força que os transcendia.

\footnotetext{
${ }^{220}$ A rainha Clitemnestra possuía a qualidade de usar ao seu favor a ambiguidade da palavra: "Senhora, falas com a sensatez de um homem sábio", [ÉSQUILO, 1992:40]. "Ouve então, pois não velarei minhas palavras / e não mais usaremos de obscuros enigmas" [EURÍPEDES, s/d:149].

${ }^{221}$ LIMA, Heber Salvador de. Os deuses que não morreram: ensaios de cultura grega. São Paulo: Loyola, 1996, p. 32.

${ }_{222}$ Ibidem, p. 32.

${ }^{223}$ Clitemnestra responde dessa forma à acusação do coro, buscando justificativa para seu ato: "Pela Justiça, que vingou a minha filha, pela Ate e pela Erínia, às quais imolei este homem, juro-te que, em mim, a esperança não pisará a casa do medo" [ÉSQUILO, 1992:89].
} 
Talvez, ainda, se possa relacionar a ideia, presente na metade da segunda estrofe do poema de Sophia Andresen, de que o mal não era algo generalizado que contaminava a natureza e a luz. No drama Eumênides ${ }^{224}$, de Ésquilo, ocorre a transformação das Erínias (Fúrias) em Eumênides pela deusa Athena, para aplacar a ira. De divindades vingadoras, sedentas do sangue e do que é selvagem, passam a ser vistas como protetoras da vegetação, da cultura, dos animais e dos homens. De representantes da culpa recalcada e destrutiva, do tormento do remorso, passam a simbolizar a mesma "culpa, porém confessada, e que se torna sublimemente produtiva. O arrependimento liberador", fato que pressupõe "uma conversão interior" $^{225}$, um retorno à ordem.

O eu lírico, na terceira estrofe, não vê a existência do mal e o seu poder de ação no palácio de Elsinore da mesma maneira. O mal não está mais circunscrito a um determinado espaço ou entidade divina como as Fúrias ${ }^{226}$. Ele torna-se um "veneno subtil" que rompe qualquer limite e contamina "o ar e a luz", que penetra a partir dos "ouvidos e das narinas."227 A partir de Elsinore, ninguém, nem mesmo o amor, poderia escapar ao poder do mal.

A morte em Micenas é cercada pelos limites estreitos da água contida na banheira. Mesmo o sangue derramado não pode contaminar nem o rio, nem a luz; somente pode contaminar os seus próprios agentes. Mas, em Elsinore, o mal invade livremente os espaços amplos que um rio contém: "O inferno vomitava a sua pestilência invadida / As veias e os rios”. Na metáfora estabelecida entre os dutos de um rio e as veias do corpo humano, são estes que carregam o mal que corroi a natureza e o homem.

\footnotetext{
${ }^{224}$ ÉSQUILO, Eumênides, Tradução de JAA Torrano. São Paulo: Iluminuras, 2004.

${ }^{225}$ CHEVALIER, Jean; GHEERBRANT, Alain. Dicionário de símbolos, Tradução de Vera da Costa e Silva. Rio de Janeiro: Loyola, 2008, p. 411.

${ }^{226}$ Quem reclama vingança é o espectro do pai de Hamlet, mas não motivado por alguma entidade divina.

${ }^{227} \mathrm{O}$ rei, enquanto dormia no jardim, foi assassinado pelo próprio irmão, Cláudio, que lhe derramou veneno na cavidade do ouvido. Cláudio lhe toma a coroa, o trono e a rainha. [SHAKESPEARE, 1979:223].
} 
No palácio do drama Hamlet, O príncipe da Dinamarca ${ }^{228}$, a morte não tem uma face, uma caracterização de traços terríveis de Clitemnestra transfigurada pela ira e pela vingança. Os atos não são assumidos de forma declarada: "No entanto, o mal não se via". Essa é a sua pior característica: a dissimulação.

As mortes que se perpetuaram não tinham uma motivação exterior, uma imposição da justiça divina que ultrapassasse o homem. Interiorizado, o mal, na perspectiva do poema, é algo pertinente à natureza das coisas e do homem, como nos indicam os três últimos versos:

$[\ldots]$

No entanto o mal não se via: era apenas

Um leve sabor a podre que fazia parte

Da natureza das coisas. 229

O mal, a partir de Elsinore, faz parte da nossa natureza humana. Não é individualizado ou específico, é coletivo, comum a todas as coisas, sendo esta a característica que o torna mais pernicioso:

O miasma [a poluição no seu sentido grego] estava nesse mundo circunscrito na invocação dos Átridas feita no poema "Elsinore" [p.68], nessa lembrança de um mundo ordenado em direção a uma finalidade sacra[...] Mas esta metáfora dos Átridas [usada nos épicos, e nos trágicos da Grécia arcaica e clássica], deixa de poder funcionar quando nos aproximamos do homem moderno, retido na metáfora shakespeareana de Elsinore: todo o corpo social se torna responsável, todos pactuam, todos originam $\left[\ldots . .{ }^{230}\right.$

Do universo trágico do palácio de Micenas, verifica-se outra personagem também trabalhada pela poesia de Sophia Andresen: Electra ${ }^{231}$, filha de Agamêmnon e Clitemnestra, está presente em dois poemas que guardam um distanciamento entre si. Embora apresentem o mesmo título, um encontra-se no livro Mar novo, de 1958, e o outro em Geografia, de 1967.

\footnotetext{
${ }^{228}$ SHAKESPEARE, William. Hamlet, o príncipe da Dinamarca, Tradução de F. Carlos de Almeida Cunha Medeiros e Oscar Mendes. São Paulo: Victor Civita, 1981.

${ }^{229}$ ANDRESEN, Sophia de Mello Breyner. Ilhas. Lisboa: Caminho, 2004, p. 74.

${ }^{230}$ MAGALHÃES, Joaquim Manuel. Rima pobre. Lisboa: Presença, 1999, p. 43-44.

${ }^{231}$ Verificar Anexo - F.
} 
“Electra”, de Mar novo, é baseada na trilogia de Eugene O’Neil, Electra Enlutada ${ }^{232}$, de 1931, na qual o mito é resgatado e levado para a época da guerra civil americana. Já o poema presente em Geografia tem forte influência do drama de Sófocles, encenado em Lisboa, em 1963, que segundo diz António Manuel dos Santos Cunha ${ }^{233}$, pode ter impressionado profundamente Sophia Andresen por causa da interpretação da atriz grega Aspassia Papathanassiou, a quem o seu poema é dedicado. Este é o poema "Electra", do livro Mar Novo, de 1958:

\author{
ELECTRA \\ à Aspassia Papathanassiou \\ O rumor do estio atormenta a solidão de Electra \\ O sol espetou a sua lança nas planícies sem água \\ Ela solta os seus cabelos como um pranto \\ E o seu grito ecoa nos pátios sucessivos \\ Onde em colunas verticais o calor treme. \\ O seu grito atravessa o canto das cigarras, \\ E perturba no céu o silêncio de bronze \\ Das águias que devagar cruzam seu vôo. \\ O seu grito persegue a mantilha das fúrias \\ Que em vão tentam adormecer no fundo dos sepulcros \\ Ou nos cantos esquecidos do palácio \\ Porque o grito de Electra é a insônia das coisas \\ A lamentação arrancada ao interior dos sonhos dos remorsos \\ [e dos crimes \\ E a invocação exposta \\ $\mathrm{Na}$ claridade frontal do exterior \\ No duro sol dos pátios \\ Para que a justiça dos deuses seja convocada ${ }^{234}$
}

A Electra, retratada no poema, possui uma personalidade forte e sabe jogar com a astúcia. É perseverante na vingança cega dos assassinos de seu pai e, para tal, não mede esforços.

\footnotetext{
${ }^{232}$ O’NEIL, Eugene. Electra Enlutda. Tradução de R. Magalhães Junior e Miroel Silveira. Rio de Janeiro: Edições Bloch, 1970.

${ }^{233}$ CUNHA, António Manuel dos Santos. Sophia de Mello Breyner Andresen: mitos gregos e encontro com o real. Lisboa: Imprensa Nacional Casa da Moeda, 2004, p. 189.

${ }^{234}$ ANDRESEN, Sophia de Mello Breyner. Geografia. Lisboa: Caminho, 2004, p. 64.
} 
Este poema traça um diálogo mais intenso com a Electra desenhada na peça de Sófocles $^{235}$. Nesta, a ira advém da morte do pai, de todas as privações pelas quais passou, como a de ter-se tornado escrava no palácio da própria mãe. É esse rancor alimentado diariamente através da lamentação constante, perturbadora, que está no centro da ação do poema. Assim, novamente, seguiremos os traços deixados pelas Fúrias, agora absorvidos pela filha de Agamêmnon ${ }^{236}$.

O poema fala da privação imposta à Electra através de uma atmosfera árida que ronda o poema inteiro. Para conseguir esse efeito, selecionam-se palavras como "estio", "solidão", “sol”, “calor" e as expressões "planícies sem água" e "duro sol”. Esse léxico está presente de uma forma mais intensa nos dois primeiros versos: “O rumor do estio atormenta a solidão de Electra / O sol espetou a sua lança nas planícies sem água."237

Sua penúria é o seu rancor, alimento diário de sua lamentação. Ela chorará insistentemente até que os deuses a ouçam e façam cumprir a justiça divina. Por isso, "gritar, "lamentar", "perturbar" e "invocar" são os verbos que aparecem no decorrer dos versos. O desejo ardente de vingança de morte a faz até esquecer-se de si mesma.

O luto pela morte de Agamêmnon é introduzido indiretamente no poema. Podemos deduzi-lo a partir do contexto do terceiro verso ("Ela solta os seus cabelos como um pranto”), o qual descreve uma tradição religiosa que, na Grécia Antiga, ligava as mulheres aos rituais

\footnotetext{
${ }^{235} \mathrm{O}$ mito de Electra foi trabalhado pelos três grandes poetas do teatro: Sófocles, Ésquilo e Eurípedes.

${ }^{236}$ Em Electra, de Sófocles, há o registro da personagem Electra ligada às Fúrias através do coro que, pressentindo sua chegada ao palácio, enxerga nela a morte e a descreve como uma Fúria: "Vêde a morte avançando fatal / e sedenta de sangue! / Acabam de transpor as portas desta casa / as Fúrias, caminhantes lentas, / perseguidoras certas da sombra culpa. / Tornar-se-á realidade logo / a nítida visão latente em meu espírito". [SÓFOCLES, 1965: 61]

${ }^{237}$ ANDRESEN, Sophia de Mello Breyner. Geografia. Lisboa: Caminho, 2004, p. 64.
} 
fúnebres $^{238}$. Para expressar o seu sofrimento, as mulheres vestiam-se de preto, arrancavam os próprios cabelos, batiam no peito, arranhavam suas faces, aos prantos e aos gritos ${ }^{239}$.

A dor profunda de Electra ecoa por entre os "pátios sucessivos", por entre as "colunas verticais”. Seus gritos percorrem os espaços vazios do palácio e do poema. O eco destes não possibilita a quietude, faz tremer as estruturas e rompe o silêncio, para que ninguém esqueça que sua dor tem sede de morte.

Nem mesmo os deuses escapam às suas lamúrias. O poema contém o elemento divino presente nas imagens da cigarra, do sol e das águias. O sol e as cigarras são representações ligadas ao deus Apolo, para o qual são feitas parte das invocações; as águias possuem uma dupla configuração, como ave consagrada a Zeus e tal qual a que simboliza a realeza de Agamêmnon $^{240}$.

Maria do Céu Zambujo Fialho no livro Luz e trevas no teatro de Sófocles, de 1992, faz alguns apontamentos importantes sobre a personalidade de Electra, presentes também no poema andresiano - é “o ser da memória viva da morte de seu pai”. Para ela, é como se cada dia fosse o dia do crime. Electra é aquela que jamais se esquece, que jamais condescende. A "força da sua revolta é também a força dos mortos apropriada pelos vivos, transformados estes em verdadeiras Erínias"241, como podemos ler no décimo verso da primeira estrofe: "Que em vão tentam adormecer no fundo dos sepulcros" do poema ${ }^{242}$.

\footnotetext{
${ }^{238}$ BURKET, Walter. Religião grega na época clássica e arcaica, Tradução de M. J. Simões Loureiro. Lisboa: Fundação Calouste Gulbenkian, 1993, p. 374.

239 A descrição dessas mulheres desesperadas, chorando seus mortos, lembra-nos aquela feita por Orestes das Erínias [Fúrias] nas Coéforas [EURÍPIDES, 2004:145].

${ }^{240}$ Vernant lembra que os Átridas também eram representados pelas águias, animais das alturas. Eram comparados aos abutres, aves de rapina devoradoras de cadáveres [VERNANT, 2008: 230].

${ }^{241}$ FIALHO, Maria do Céu Zambujo, Luz e Trevas no Teatro de Sófocles, Coimbra, Instante Nacional de Investigação Científica Centro de Estudos Clássicos e Humanísticos da Universidade de Coimbra, 1992, p. 157.

${ }^{242}$ ANDRESEN, Sophia de Mello Breyner, Geografia, Lisboa, Caminho, 2004, p. 64.
} 
O verso "E perturba no céu o silêncio de bronze", que antecede aquele em que está presente a figura das águias, remete à imagem de Clitemnestra, em dois sentidos relacionados ao metal: por um lado, como metal, a palavra "bronze" indica a arma que a rainha utilizou para matar Agamêmnon, o machado; por outro, com a noção simbólica que carrega o sentido de som, implicando um instrumento que tem $\operatorname{voz}^{243}$. Então, podemos fazer uma analogia entre a voz que emana do bronze e a voz de Electra. Na sua lamentação, rompe-se o silêncio do céu ao se cobrar dos deuses justiça pelo ato bárbaro de sua mãe contra seu pai.

Sua sede de vingança ecoa no poema e é marcada pela intensidade, provavelmente impulsionada pelo desejo e prazer que o possível sofrimento imposto aos assassinos de seu pai pode lhe proporcionar. Electra é a voz do desejo. No entender de Octavio Paz, “é a própria voz de ser, porque o ser não é outra coisa senão o próprio desejo de ser" ${ }^{\text {244 }}$. Nada pode aplacar essa busca. Na peça de Sófocles, o coro tem a percepção do excesso que habita as lamúrias e pede moderação (vv.164-169):

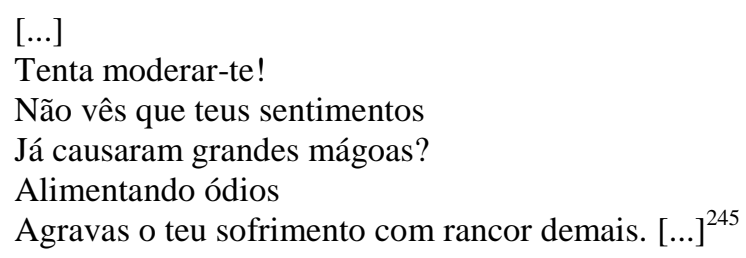

A grandeza de Electra, tanto no poema andresiano quanto no drama de Sófocles, é exatamente a sua inflexibilidade. O poema apresenta uma personagem que não se curva ou se dobra perante os obstáculos. Ela não teme a morte, mas quer ser sua mensageira. Essa inflexibilidade diante do destino é o código de honra do herói ${ }^{246}$, traço que permite que ela compartilhe do sagrado como Electra/Fúria.

\footnotetext{
${ }^{243}$ CHEVALIER, Jean; GHEERBRANT, Alain, Dicionário de Símbolos, Tradução de Vera da Costa e Silva, Rio de Janeiro, Loyola, 2008, p. 144.

${ }^{244}$ PAZ, Octavio, O Arco e a Lira, Tradução de Olga Savary, Rio de Janeiro, Nova Fronteira, 1984, p. 220.

${ }^{245}$ SÓFOCLES, Electra. Tradução de Mário da Gama Kury. Rio de Janeiro: Civilização Brasileira, 1965, p.7.

${ }^{246}$ Conforme aponta Trajano Vieira no ensaio de Electra(s). [SÓFOCLES, EURÍPIDES, 2009:10].
} 
Electra não permite que as Fúrias esqueçam um só momento a razão de seu sofrimento: "O seu grito persegue a matilha das fúrias / Que em vão tentam adormecer no fundo dos sepulcros". Cobra o justo preço dos que derramaram o sangue de seu pai. Helene P. Foley, em Female acts in Greek tragedy, reconhece, na lamentação agressiva e sistemática, feita por Electra, traços de uma Fúria ao atormentar e amedrontar Clitemnestra, comentário que também podemos estender ao poema andresiano:

Like a Fury, she tortures Clytemnestra, making her fearful and defensive. Her verbal control of the stage increases throughout the first half of the play; Clytemnestra is afraid to pray openly to Apollo [...]. ${ }^{247}$

Electra é firme em sua missão particular de ser o tormento de Clitemnestra. Sua cobrança causa-lhe insônia, está dentro e fora de Clitemnestra, não a deixando dormir, assim como fazem as Fúrias - "Porque o grito de Electra é a insônia das coisas / A lamentação arrancada ao interior dos sonhos dos remorsos e dos crimes".

Há uma palavra chave nesses dois versos: "grito", que liga as duas personagens. O grito de Electra impõe a Clitemnestra o tormento e a insônia. Isso faz com que a rainha sinta remorso dos crimes através dos sonhos e perca o sono. Essa palavra também tem ligação com o sonho da rainha, que está descrito nas Coéforas $^{248}$. Clitemnestra sonha que pariu uma serpente e ao amamentá-la, esta lhe fere o peito: "Ela do sono lançou um grito de pavor ${ }^{249}$. É esse sonho que dá a Electra a certeza de punição à sua mãe.

Os três últimos versos da segunda estrofe referem-se à invocação que Electra faz, apontando para mais uma diferença entre ela e a mãe. No drama de Sófocles, depois do sonho terrível, Clitemnestra faz libações noturnas para aplacar a ira do rei.

\footnotetext{
${ }^{247}$ FOLEY, Helene P. Female acts in Greek tragedy. New Jersey: Princeton University Press, 2003, p. 151.

${ }^{248}$ ESQUILO, Coéforas, Tradução de JAA Torrano, São Paulo: Iluminuras. 2004, p. 109.

${ }^{249}$ Ibidem, pág. 109.
} 
No poema andresiano, o eu lírico procura estabelecer relações intrínsecas entre Electra e a justiça do deus Apolo, na ordenação da invocação: esta só poderia ocorrer na "claridade frontal do exterior", pois traz, internamente, o conceito de "justiça divina", que jamais poderia ocorrer no interior do palácio, pois este se encontrava poluído, imerso em sombras (domínio das Fúrias). A justiça de Apolo, mesmo sendo divina, é implacável e impiedosa como um “duro sol”. Electra a convoca porque somente ela poderá restabelecer o equilíbrio e a ordem das coisas.

Sophia Andresen também faz uma menção sobre esta invocação no livro $O$ nu na antiguidade clássica, de 1975, ressaltando como a justiça compartilha da ordem sob o ponto de vista divino:

\begin{abstract}
A Electra de Sophocles, ao sair de um interior povoado de gritos e gemidos, erguese no limiar da casa dos Atridas e, antes de iniciar a lamentação, antes de iniciar o relato da dor, da injustiça e do crime, invoca nestas a ordem das coisas, ordem na qual, para além de todo o desastre e sofrimento, repousa a sua confiança (...). ${ }^{250}$
\end{abstract}

Como já vimos, nos três últimos versos da primeira estrofe, Electra também conclama as divindades ctônias, infernais, como as Fúrias ${ }^{251}$. Esse fato implica que, apesar da invocação à claridade do deus Apolo, Electra também comunga com toda possibilidade de violência que estas divindades terríveis possam significar. Isso ocorre porque é natural à Electra a polarização de forças extremas, incorporadas a sua personalidade forte e dominadora. Assim, o poema não poderia situá-la em uma faixa banhada somente pela "claridade" nem a toda significação positiva que esta possa conter, pois ela também está imersa nas sombras da noite.

\footnotetext{
${ }^{250}$ ANDRESEN, Sophia de Mello Breyner. O nu na antiguidade clássica. Lisboa: Caminho, 1992, p.17.

${ }^{251} \mathrm{Na}$ mesma invocação feita à claridade da justiça do deus Apolo, há também invocações às divindades infernais: Hades, Persefone, Hermes infernal, Maldição divina e às augustas Fúrias [SÓFOCLES, 1965:4]
} 
Na Electra de Eurípedes, depois de ajudar Orestes a matar Clitemnestra, ela assume: "Sou responsável pelo horror do excesso / A fúria me incendiou. ${ }^{, 252}$

O poema "Electra", que consta no livro Mar novo, de 1958, dialoga com o esvaziamento do mito que ocorre na peça Eugene O’Neil:

\author{
Os muros da casa dos Manon escorrem sangue \\ $\mathrm{E}$ as árvores do jardim escorrem lágrimas. \\ O lago busca em vão o reflexo antigo duma infância \\ Que se tornou homens, mulheres, ódios e armas. \\ Numa janela aparecem duas mãos torcidas \\ E nos corredores ressoam as palavras \\ Da traição, da náusea, da mentira \\ E o tempo vestido de verde senta-se nas salas. \\ O rosto de Electra é absurdo \\ Ninguém o pediu e não pertence ao jogo. \\ As suas mãos vingadoras destoam na conversa \\ Assustam a penumbra e ofendem o pecado. ${ }^{253}$
}

O drama Electra Enlutada ${ }^{254}$ é inspirado na obra Orestéia, do poeta grego Ésquilo. O autor, porém, optou pelo esvaziamento do mito dos Átridas para explorar elementos pertinentes à psicologia freudiana que giram em torno do complexo de Electra, através da na paixão intensa que a filha, Lavínia, sente pelo pai (contrário ao de Édipo, que ama a mãe).

O poema pode ser dividido em dois momentos: o primeiro, ao referir a casa dos Manon e às intrigas e fatalidades que a cercam, principalmente às ações de Lavínia; o segundo, apresenta Electra.

Os dois primeiros versos ("Os muros da casa dos Manon escorrem sangue / E as árvores do jardim escorrem lágrimas”) remetem à ideia já anteriormente expressa no poema

\footnotetext{
${ }^{252}$ EURÍPEDIS. Electra. In: Electra(s), Tradução de Trajano Vieira. Cotia: Ateliê Editorial, 2009, p. 125.

253 ANDRESEN, Sophia de Mello Breyner. Mar novo. Lisboa: Caminho, 2003, p. 44.

${ }^{254}$ O’NEIL, Eugene. Electra Enlutada. Tradução de R. Magalhães Junior e Miroel Silveira. Rio de Janeiro: Edições Bloch, 1970.
} 
"Elsinor”. O mal circunscreve a um núcleo familiar, em um determinado espaço, que é a casa dos Manon. $\mathrm{O}$ aspecto macabro e trágico da história está expresso tanto na imagem dos muros que escorrem sangue quanto na das árvores que choram.

Nas duas primeiras estrofes, o eu lírico opta por uma grande quantidade de substantivos na construção dos versos, como "muros", "casa", "Manon”, “sangue”, “árvores”. “jardim”, "lágrimas”, "lagos”, "homens”, "mulheres”, entre outros, fato que busca concretizar a materialidade de um mundo finito e limitado, marcado pela violência do "ódio". Isto reforça o caráter negativo deste espaço.

A maneira como a poeta organiza os nomes através do espaço, segundo o crítico literário Joaquim Manuel Magalhães, indica uma opção:

\begin{abstract}
Aqui ocorre o segundo funcionamento concomitante que pretendi adivinhar como razão dessa capacidade na poesia; e na poesia de Sophia Andresen em particular. O da selecção lexical; o da opção alcançada por um modo de referenciar que seja, desde logo, um modo de ter encontrado palavras justas para o peculiar efeito de beleza que o poema demanda; ou que são nelas próprias a demanda do poema. ${ }^{255}$
\end{abstract}

Nos versos "O lago busca em vão o reflexo antigo duma infância / Que se tornou homens, mulheres, ódios e armas", a palavra "lago" possui a função de ser como um portal mágico que liga uma realidade a outra. No entanto, falha na tentativa de ser o reflexo de uma época primordial e sagrada que foi a infância. Consegue refletir apenas um mundo adulto já totalmente corrompido pelo ódio.

Nas duas estrofes seguintes, os versos apresentam um movimento que sintetiza a trajetória de Lavínia, no decorrer da trilogia, e a tensão que se estabelece entre mãe e filha. O verso "Numa janela aparecem duas mãos torcidas" retrata a situação da filha que vivia à sombra da mãe poderosa e sua impossibilidade de ação diante da presença da mãe.

\footnotetext{
${ }^{255}$ MAGALHÃES, Joaquim Manuel. Rima pobre. Lisboa: Presença, 1999, p.41.
} 
Com o segundo verso da quarta estrofe ("E o tempo vestido de verde senta-se nas salas"), a transição de Lavínia tem o seu desfecho. Quando Christine aparece, pela primeira vez na peça, veste-se com um sensual vestido verde, é uma pessoa atraente. Em seguida, surge Lavínia, aparentando mais idade do que tem, com um vestido preto e comum, uma pessoa amargurada. Assim, a expressão "e o tempo vestido de verde", representa não somente a passagem de tempo, mas a transformação de Lavínia depois da morte de Christine e de ter liberada sua verdadeira personalidade, reprimida até então.

Na peça de Eugene O’Neil o que motiva as ações trágicas é o conflito psicológico de cada personagem, em choque uns com os outros, construindo uma complexa rede de intrigas e traições nos labirintos do ser humano. Não há mais a questão do destino, da ananke (termo grego para a fatalidade). Os homens não estão mais sob o poder dos deuses e, portanto, não há mais embate, luta, questionamento do herói diante de seu destino trágico.

Para Raymond Willians, em Electra Enlutada os relacionamentos são criados dramaticamente a partir da consciência. $\mathrm{O}$ que parece ser um drama familiar é, na realidade, um drama particular. Cita uma fala do próprio Eugene O’Neil, em que deixa isso claro:

[...] alcançar uma moderna abordagem psicológica do sentido grego do destino numa peça como esta, que o inteligente público de hoje que não tem qualquer crença nos deuses ou na punição sobrenatural, possa aceitar, sendo por ela afetado. ${ }^{256}$

Os versos da última estrofe tomam, no entanto, um novo rumo. A aparente dissolução do mito é revertida dentro do poema, pois surge Electra: "O rosto de Electra é absurdo". Ela tem a face atormentada pelo desejo de vingança das Fúrias.

Electra, assim como Clitemnestra, possui uma estrutura muito simplista: ela é direta, conhecemos desde o início sua sede insaciável de morte. Portanto, torna-se um corpo

\footnotetext{
${ }^{256}$ WILLIAMS, Raymond. Tragédia moderna, Tradução de Betina Bischof. São Paulo: Cosac \& Naify, 2002, p.157.
} 
estranho, invasor, além de "não pertencer ao jogo" da dissimulação estabelecido por Lavínia. Ninguém solicitou sua presença.

Em Electra, nada é íntimo, interior ou dissimulado. Tudo é externo. Mesmo quando envolvida nas sombras da noite, ela nos obriga a enfrentar a figura medonha da Fúria e, portanto, destoa da primeira ideia do poema, que não crê que o ser humano é governado pelo destino. Em decorrência disso, o poema indica que a presença de Electra lhe é um corpo estranho: "Ninguém o pediu e não pertence ao jogo".

No drama de Eugene O’Neil, a partir do momento em que não há uma lei punitiva para Lavínia, expressa por algum deus ou divindade, as mãos vingativas de Electra/Fúrias ficam sem sentido e apontam a nulidade de sua presença, como nos indica o verso: "As suas mãos vingadoras destoam na conversa". Em decorrência da falta de um deus punitivo, Lavínia, ao final da peça, penitencia a si própria, encerrando-se no interior da mansão dos Manon. Fecha todas as janelas, impedindo que a luz entre. Sua casa será seu túmulo:

\begin{abstract}
Eu sou a última Mannon. [...] Quero viver a sós com os mortos, e guardar os seus segredos, e deixar que me persigam, até que a maldição seja paga e o último Mannon possa ser deixado para morrer. (Com um estranho e cruel sorriso de volúpia e regozijo pelos anos de autotortura). Eu sei que eles providenciarão que eu viva uma vida longa! Os Mannon têm de punir a si mesmos por terem nascido. ${ }^{257}$
\end{abstract}

Talvez esses atos sejam as causas por que, no poema "Electra", "Assustam a penumbra e ofendem o pecado", pois com o esvaziamento de qualquer aspecto divino, na ação punitiva, por uma determinada falta, passa a não existir o elemento que o torna grandioso: a luta trágica do homem contra seu destino determinado pelos deuses.

José Pedro Serra aponta as diferenças fundamentais entre Lavínia e Electra:

\footnotetext{
${ }^{257}$ WILLIAMS, Raymond. Tragédia moderna, Tradução de Betina Bischof. São Paulo: Cosac \& Naify, 2002, p.159.
} 
[...] a psicanálise descentrou o homem relativamente a si próprio e à sua 'razão' como sede da sua mais profunda identidade; o homem exilou-se de si próprio, constituindo-se num olhar reflexivo, como um imenso enigma. Ao contrário da tragédia grega, o herói não está já às mãos do destino, da fatalidade e dos deuses; agora, são os becos da alma, os sinuosos abismos da sua vida psíquica que o interrogam e desafiam. A pergunta da Esfinge, contudo, mantém-se. ${ }^{258}$

Roberto Calasso, no livro A literatura e os deuses, verificou que se o "olhar não tem uma imagem sobre a qual repousar", a partir do momento em que nos falta uma mediação entre o que ele chama de "fantasma mental" e algo que possui uma "existência concreta". Somos invadidos por um sentimento muito intenso, muito antigo, que é a angústia, “decorrente da ausência de ídolos"259.

Ao dar forma a todas essas imagens fortes e assustadoras, através do logos poético, resgatando-as do mais profundo caos interno humano e liberando-as para luz do poema, Sophia Andresen tenta resgatar e manter o equilíbrio entre forças tão contrárias e titânicas que nos são comuns. Tenta construir um retrato aproximado do ser humano, nas suas mais variadas potencialidades, quer antigo, quer contemporâneo, que resulta da luta intensa de reconhecer-se, de desvelar o que temos de luz e de sombras.

A presença do elemento sagrado na poesia andresiana, como representação poética de um mundo original que busca a sublimação, através da arte, como nos lembra Octavio Paz, também aponta para o inverso: “[...] no sublime há sempre um tremor, um mal-estar, um pasmo e uma aflição que denunciam a presença do desconhecido e do incomensurável, traços do horror divino ${ }^{260}$.

\footnotetext{
${ }^{258}$ SERRA, José Pedro. Electra ou a Voz do Hades, in: Jornal Lisboa MITE '06. Lisboa. <http://www.teatrodmaria.pt/media/pdf/JORNAL_02_SITE.pdf>. Acesso em 30/09/2010.

${ }^{259}$ CALASSO, Roberto. A literatura e os deuses, Tradução de Jônatas Batista Neto. São Paulo: Companhia das Letras, 2004, p. 86.

${ }^{260}$ PAZ, Octávio, $O$ arco e a lira, Tradução de Olga Savary. Rio de Janeiro: Nova Fronteira, 1984, p. 171.
} 
No poema "Medeia", que está no livro Dia do mar de 1947, podemos encontrar os elementos que Octavio Paz cita acima, tão contrários entre si, como a sublimação e o horror, mas trazem equilíbrio para o espaço do poema:

\author{
MEDEIA \\ (Adaptado de Ovídio) \\ Três vezes roda, três vezes inunda \\ $\mathrm{Na}$ água da fonte os seus cabelos leves, \\ Três vezes grita, três vezes se curva \\ E diz: "Noite fiel aos meus segredos, \\ Lua e astros que após o dia claro \\ Iluminais a sombra silenciosa, \\ Tripla Hecate que sempre me socorres \\ Guiando atenta o fio dos meus gestos, \\ Deuses dos bosques, deuses infernais \\ Que em mim penetre a vossa força, pois \\ Ajudada por vós posso fazer \\ Que os rios entre as margens espantadas \\ Voltem correndo até às suas fontes. \\ Posso espalhar a calma sobre os mares \\ Ou enchê-los de espuma e fundas ondas, \\ Posso chamar a mim os ventos, posso \\ Largá-los cavalgando nos espaços. \\ As palavras que digo e cada gesto \\ Que em redor do seu som no ar disponho \\ Torcem longínquas árvores e os homens \\ Despedaçam-se e morrem no eco. \\ Posso encher de tormento os animais, \\ Fazer que a terra cante, que as montanhas \\ Tremam e que floresçam os penedos." 261
}

Medeia era a temível feiticeira da Cólquida, filha de Eetes. Sob domínio de Eros e Afrodite, apaixonou-se perdidamente por Jasão, chefe dos Argonautas, que buscava o Velocino de Ouro. Este foi ajudado por Medeia, através de sua mágica. Depois de casar-se com Jasão, foi traída por este. Cega de paixão e ira, para vingar-se de Jasão, entre outros crimes, matou os próprios filhos.

Este poema é uma adaptação condensada de dois trechos do poema do livro VII, de Metamorfoses $^{262}$, de Ovídio: Jasão pede a Medeia que remoce Esão, seu pai; III - Invocação

\footnotetext{
${ }^{261}$ ANDRESEN, Sophia de Mello Breyner. Dia do Mar. Lisboa: Caminho, 2003, p. 67.
} 
de Medeia. Esão é rejuvenescido. O poema Metamorfoses foi escrito em verso hexâmetro datílico, formado de seis sílabas métricas. Essa medida, segundo João Angelo Oliva Neto ${ }^{263}$, "pode acolher teoricamente uma sequência de palavras que somem de 12 a 17 ou 18 sílabas", constituindo um verso longo.

Ao adaptar os dois trechos do Livro VII, Sophia Andresen optou, assim como Bocage, no século XVIII, pelo verso decassílabo, que é menor. João Angelo Oliva Neto tem uma explicação para essa escolha feita por Bocage quando traduziu o poema, o que pode explicar a escolha da poeta. Entre outras razões, é porque o verso torna-se mais conciso, dinâmico ritmicamente e mantém as imagens:

\begin{abstract}
Mas o princípio geral - admitida essa possibilidade - que nos parece nortear a versão de Bocage é a fluência, vale dizer, o ritmo. Não se trata do compasso, dado aqui pelo decassílabo, que se repete, mas do movimento do sentido e da imagem ao longo do compasso, no dizer de Octavio Paz. O texto de Bocage tem o condão de se fazer ler e ouvir sem que se percam o tom, as imagens e, principalmente, o deleite na compreensão. ${ }^{264}$
\end{abstract}

"Medeia", de Sophia Andresen, assim como Metamorfoses de Ovídio, é um poema narrativo. No recorte feito pela poeta, não há citação do pedido feito por Jasão a Medeia para rejuvenescer seu pai, Esão. Toda a narrativa concentra-se na figura poderosa de Medeia e de seu desejo de compartilhar o temível poder divino de Hecate e os deuses infernais.

Podemos dividir o poema em quatro partes: na primeira, os três versos iniciais descrevem os vários atos ritualísticos praticados por Medeia; na segunda, do quarto ao nono verso, é o momento no qual Medeia assume a voz do poema e enumera vários deuses e elementos naturais com os quais quer compartilhar da força divina; na terceira, do décimo ao

\footnotetext{
${ }^{262}$ Metamorfoses, do poeta romano Públio Ovídio Naso, é um poema narrativo, que mostra o mundo em contínuo processo de mutação. É dividido em 15 livros, e seus 12 mil versos têm como tema a cosmogonia e a história do mundo. Foi escrito em hexâmetro datílico, no século VIII d.C. Verificar Anexo - G.

${ }^{263}$ OVÍDIO, Metamorfoses. Tradução de Bocage. Introdução de João Angelo Oliva Neto. São Paulo: Hedra, 2007 , p. 26.

${ }^{264}$ OVÍDIO, Metamorfoses. Tradução de Bocage. Introdução de João Angelo Oliva Neto. São Paulo: Hedra, 2007, p. 31.
} 
décimo- sétimo verso, descreve o poder assombroso de sua mágica; na quarta, do décimooitavo ao vigésimo quarto e último verso, dá-se a conhecer o meio através do qual todo esse poder se realiza: a palavra.

Nos três primeiros versos ("Três vezes roda, três vezes inunda / $\mathrm{Na}$ água da fonte os seus cabelos leves / Três vezes grita, três vezes se curva"), a repetição da expressão "três vezes", tanto no início quanto no interior do verso, permite uma série de conjecturas ou justificativas para a sua presença no poema.

Primeiramente, a repetição de certas palavras, como por exemplo, a expressão "três vezes" ou o verbo "posso", faz com que o poema ganhe certa musicalidade, um ritmo marcado. Aponta para uma ordenação dos atos ritualísticos de Medeia e impõe um ritmo que permeará todo o poema. A musicalidade é um elemento característico tanto para o poema quanto para o ritual mágico que Medeia inicia. Segundo Clara Rocha, o culto poético, presente na poesia andresiana, "implica um cerimonial composto de espaços próprios, de gestos, de ritmos, de palavras e até duma dicção inconfundível, hierática e solene”265.

O número "três", nesse processo ritualístico, faz uma ligação direta com a imagem da deusa Hécate, por seu epíteto ser "Tripla": "Em suas imagens ela aparecia com três corpos ou

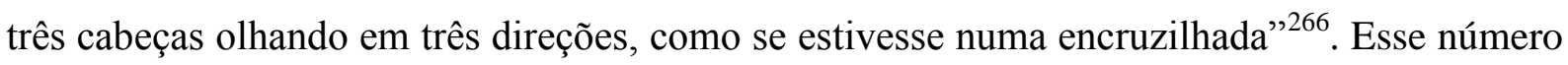
também aponta para a trindade entre o divino, o homem e natureza. Segundo Ernst Cassirer, os números comportam "a peculiaridade do sentimento mítico de espaço” (a fonte de água), "do sentimento mítico do tempo" (três vezes roda) e "do sentimento mítico do eu"267 (três

\footnotetext{
${ }^{265}$ ROCHA, Clara. "Nos 50 anos de vida literária de Sophia. Sophia de Mello Breyner Andresen: poesia e magia". In: Colóquio Letras, n. 132/133. Lisboa, 1994, p. 172.

${ }^{266}$ KURY, Mário da Gama. Dicionário de mitologia grega e romana. Rio de Janeiro: Jorge Zahar Editor, 1999, p. 172.

${ }^{267}$ CASSIRER, Ernst. A filosofia das formas simbólicas, Tradução de Cláudia Cavalcanti. São Paulo: Martins Fontes, 2004, p. 254.
} 
vezes grita, três vezes se curva). Lembramos, também, que a imagem da água da fonte indica purificação além do próprio fluir do tempo.

A partir do quarto verso, o eu lírico cessa sua narrativa e cede a voz para Medeia. Esta inicia a sua invocação aos elementos e aos deuses com os quais compartilha. O primeiro elemento é a figura da Noite, com seu véu de escuridão, que ajuda a ocultar as ações e todas as potencialidades de existência - "E diz: Noite fiel aos meus segredos"; depois, a Lua e os astros, que surgem "após o dia claro", conforme o quinto verso.

Além de fazerem parte da natureza de Medeia, na sua condição de feiticeira, Noite, Lua e astros, são elementos comuns à deusa Hecate. Sua imagem triforme a ligava às três fases da evolução da Lua. Há certa cumplicidade entre as duas, expressa no sétimo e oitavo versos: "Tripla Hecate que sempre me socorres / Guiando atenta o fio dos meus gestos".

O aspecto noturno do ritual também está presente nas características dos “deuses infernais", no nono verso. Hecate era uma deusa ctônia. Seus rituais dos deuses infernais deviam ser realizados no período noturno. O mito também a liga intensamente à natureza.

Ao invocar Hecate, Medeia espera que a deusa seja o elo entre os três níveis do mundo: os infernos, a terra e o céu. É a deusa dos mortos, dos espectros e dos terrores noturnos e monstros que infundem o terror ${ }^{268}$. Na tradução da peça de Eurípedes, Medeia, feita por Sophia Andresen, a feiticeira reconhece sua ligação com a deusa Hecate ao lamentar a traição de Jasão para o corifeu:

Pela deusa tutelar que escolhi, por Hécate que reside no fundo mais profundo do meu lar, juro que nenhum deles se rirá do meu tormento. Eu tornarei amargas e sinistras as suas núpcias, amarga a sua aliança e o exílio que me expulsa. ${ }^{269}$

${ }^{268}$ CHEVALIER, Jean; GHEERBRANT, Alain. Dicionário de Símbolos. Tradução de Vera da Costa e Silva. Rio de Janeiro: José Olympio, 2008, p. 484.

${ }^{269}$ EURÍPEDES. Medeia, Tradução de Sophia de Mello Breyner Andresen. Lisboa: Caminho, 2006, p. 35. 
Retomando o poema "Medeia", o terceiro momento inicia-se com o verso, "Que em mim penetre a vossa força $[\ldots]^{\natural 270}$. Há o pedido para que as forças destas potências divinas sejam incorporadas por ela. Nos sete versos seguintes, temos as descrições do poder de controle que a feiticeira tem sobre dois elementos naturais, a água e o ar:

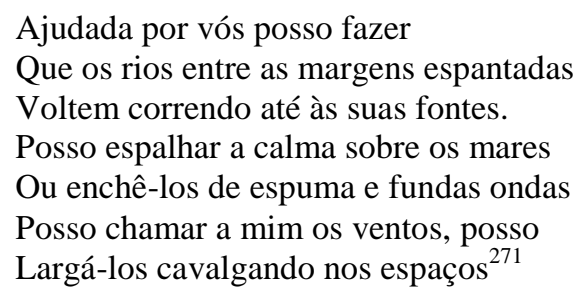

Tudo depende do estímulo ao qual a paixão de Medeia responde. No drama de Eurípedes, a própria feiticeira reconhece que a paixão sobrepõe-se ao desejo quando decide matar: “[...] mas a paixão é mais forte do que o desejo e é da paixão que nasce o pior mal dos homens."272

Nos últimos sete versos, além de Medeia fechar o círculo dos elementos naturais, sobre os quais tem poder, ela nos diz qual o instrumento que permite possuir tal força: "As palavras que digo e cada gesto / Que em redor do seu som no ar disponho"

O pensamento do poder mágico que a palavra possui está muito presente na obra de Sophia Andresen. É através da palavra poética que a poeta busca resgatar do caos e da escuridão os objetos. Ao nomeá-los, ordena o mundo. Octavio Paz, no livro $O$ arco e a lira, de 1956 , lembra que ninguém pode negar o poder mágico das palavras ${ }^{273}$. A palavra poética é mágica com o sentido de que a poesia, como linguagem, é “capaz de transcender o sentido disto e daquilo e de dizer o indizível.,274

\footnotetext{
${ }^{270}$ ANDRESEN, Sophia de Mello Breyner, Dia do Mar, Lisboa: Caminho, 2003, p. 67.

271 ANDRESEN, Sophia de Mello Breyner. Dia do Mar. Lisboa: Caminho, 2003, p. 67.

${ }^{272}$ EURÍPEDES. Medeia, Tradução de Sophia de Mello Breyner Andresen. Lisboa: Caminho, 2006, p. 62.

${ }^{273}$ PAZ, Octávio. O arco e a lira, Tradução de Olga Savary. Rio de Janeiro: Nova Fronteira, 1982, p. 61.

${ }^{274}$ Ibidem. 128.
} 
No poema, somente depois da frase "As palavras que digo [...]" é que Medeia relata o poder de seus atos ${ }^{275}$ :

Torcem longínquas árvores e os homens

Despedaçam-se e morrem no eco.

Posso encher de tormento os animais

Fazer que a terra cante, que as montanhas

Tremam e que floresçam os penedos. ${ }^{276}$

Nos versos anteriores, as imagens que surgiram, através do encanto da palavra poética, foram os rios, mares e vento. Agora, temos a matéria sólida, minerais, árvores, animais e os homens fechando o círculo dos elementos que compõem a natureza. Não há nada que escape ao poder de sua palavra. Ela pode fazer florir, criar vida em um penedo, em uma rocha, mas também pode atormentar, despedaçar e matar.

Existe uma aura tensa e atormentada na relação que Medeia estabelece com a palavra encantada, pois os verbos nos cinco últimos versos carregam um aspecto violento em relação à morte: torcer, despedaçar, atormentar, tremer. Mesmo os verbos "cantar" e "florescer", presentes nos dois últimos versos, mantêm a tensão ao seu redor.

A imagem de homens despedaçados não aparece no poema Metamorfoses, de Ovídio, como aponta Ana Helena Cizotto Belline, no ensaio "Mito e história na obra poética de Sophia de Mello Breyner Andresen”, em Estudos portugueses e africanos ${ }^{277}$. A justificativa para a introdução dessa imagem, no seu entender, poderia ser uma "referência ao irmão de

\footnotetext{
${ }^{275}$ No drama de Eurípedes, Medeia, também é astuciosa ao lidar com a palavra, e tem consciência disso: "Para mim o homem injusto que fala com habilidade merece o castigo mais rigoroso. Pois esse homem sabe que pode esconder a sua injustiça sob o véu das palavras virtuosas e comete sem medo os maiores crimes. Mas a sua habilidade não é total. Não venhas também tu exibir em minha frente a tua eloquência e a tua bela máscara. Com uma palavra te venço [...]" [EURÍPIDES, 2006:40].

${ }^{276}$ ANDRESEN, Sophia de Mello Breyner. Dia do Mar. Lisboa: Caminho, p. 67.

${ }^{277}$ BELLINE, Ana Helena Cizotto. Mito e história na obra poética de Sophia de Mello Breyner Andresen. In: Estudos portugueses e africanos, n. 07 São Paulo, 1986, p. 121-139.
} 
Medéia, Absirto (embora se deva ressaltar que a feiticeira não se serviu da sua arte para o assassinato) ${ }^{, 278}$.

Há outra possibilidade para explicar a violência a partir da presença desses verbos implica nos dois poemas, mas principalmente para o verbo "despedaçar", presente apenas no poema andresiano. É o fio que liga a imagem de Medeia às Bacantes (Mênades) e, indiretamente, ao deus Dioniso.

No artigo do jornal O Estado de S. Paulo, Civilização e barbárie em Medeia, Adriane da Silva Duarte localiza alguns pontos em comum entre a feiticeira da Cólquida e o deus do teatro. Como uma bacante, Medeia se "entrega ao irracional, liberando a natureza selvagem e a violência." ${ }^{279}$ Os homens despedaçados nos remetem à imagem terrível do corpo de Penteu despedaçado pelas bacantes, entre elas, a própria mãe.

Não podemos esquecer também que Medeia é passional. Suas ações são motivadas por Eros, pela paixão cega por Jasão. A mesma paixão que o salvou e o ajudou a edificar seu mito, também o destruiu e da maneira cruel, através da morte dos próprios filhos.

A união entre o divino, a natureza e o ser humano é costurada no poema pelo "fio atento dos gestos" de Medeia. É a cegueira da paixão desmedida pelo objeto de desejo que a impulsiona para o bem ou para o mal. A violência, portanto, está implícita nos três níveis: no humano, no divino e na natureza. Este, ao mesmo tempo que causa assombro, também fascina.

A natureza que permeia todo o poema carrega, em seu excesso, um traço de êxtase, tanto na continuidade da vida ("Fazer que a terra cante, que as montanhas / Tremam e que

\footnotetext{
${ }^{278}$ BELLINE, Ana Helena Cizotto. "Mito e história na obra de Sophia de Mello Breyner Andresen". In: Estudos portugueses e africanos, n. 7. São Paulo, 1986, p. 131.

${ }^{279}$ DUARTE, Adriane da Silva. "Civilização e Barbárie em Medéia". In: O Estado de S. Paulo n.584. São Paulo, 1991, p. 4.
} 
floresçam os penedos") quanto na violência (“Torcem longínquas árvores e os homens / Despedaçam-se e morrem no eco"). Para Bataille, "a própria natureza é violenta". Tanto no homem quanto na natureza há "um movimento que excede os limites e que nunca pode ser reduzido senão parcialmente". 280

Ainda podemos apontar duas possibilidades de leitura deste poema. Uma tem relação com a deusa Hecate e a sua presença no poema através da invocação feita por Medeia. Como já observado antes, há, entre a deusa e a feiticeira, fios que as ligam. Assim, o poema poderia apresentar-se como uma ode à deusa das encruzilhadas e a seu temível poder.

No mundo grego, a virtude do herói sempre estava baseada na relação que este tinha com determinado deus. A partir desse ponto pode-se subentender que, quando a feiticeira da Cólquida enumera as ações extraordinárias e terríveis que pode realizar ao compartilhar o poder de Hecate, tanto para o bem quanto para o mal, celebra a si mesma e demonstra quão grande é o seu poder e o quanto de respeito e temor ela pode inspirar. Pode-se considerar tal possibilidade a partir do momento em que o verbo "posso" aparece cinco vezes nos últimos versos do poema.

O poder que Medeia possui e compartilha de Hecate é uma forma de controle através do medo de sua poderosa magia, que traz intrínseca a ameaça constante da morte. Assim como os outros poemas, verificados até o momento, é o medo da morte, o medo do nada, do vazio, do desconhecido que faz com que o sujeito aprenda algo sobre si mesmo, sobre sua finitude e que, impulsionado pelo próprio medo, permite a transformação de si e de todas as coisas do mundo.

\footnotetext{
${ }^{280}$ BATAILLE, Georges. O erotismo, Tradução de Antonio Carlos Viana. São Paulo: L\&PM, 1987, p. 37.
} 
Ao analisar a presença dos deuses gregos na poesia de Sophia Andresen, Ana Helena Cizotto Belline ressalta que esse resgate não pode, de maneira nenhuma, ser considerado como um movimento de retorno a uma poesia que se quer clássica:

Ao inserir o mito tradicional na sua subjetividade de poeta, modificando-o e unindo-
o aos seus mitos pessoais, de maneira a ser compreendido somente dentro do
contexto da obra, Sophia não está retomando a antiguidade clássica - e daí ser
questionável a sua classificação como poeta clássica - mas acompanha um processo
da poesia moderna, a qual tenta "instituir" um modo de sentir e ver, cuja
universidade, justamente, reconhece como rompida e irreconstituível"281

O poema "Medeia" parece ser um bom exemplo de como a poesia andresiana, ao falar do divino, está tratando do universo humano e de toda a sua complexidade, trazendo para o espaço do poema palavras tão contrárias entre si como luz, sombra, harmonia, equilíbrio, fúria, ira, angústia, vida, morte e dúvida. A presença desses elementos opostos, segundo Octavio Paz, formam a unidade do poema que "só consegue se constituir pela plena fusão dos contrários”282. Essa luta é a sua pulsão de vida, é o que permite que esteja vivo.

Para Octavio Paz, as palavras não estão nem dentro nem fora, pois estas são nós mesmos, "fazem parte de nosso ser" ${ }^{283}$. Porém, ele lembra que a palavra poética nos coloca com o Outro que existe em nós mesmos:

A palavra poética é a revelação de nossa condição original porque por ela o homem, na realidade, se nomeia outro, e assim ele é ao mesmo tempo este e aquele, ele mesmo e o outro. ${ }^{284}$

Essa definição para a palavra poética, de certo modo, também pode estender-se à presença da imagem das Fúrias na poesia andresiana. O medo, o terror, a fúria, a sede de vingança, o pavor e a incompreensão da morte são sentimentos primitivos antigos, tanto

\footnotetext{
${ }^{281}$ BELLINE, Ana Helena Cizotto. "Mito e História na Obra Poética de Sophia de Mello Breyner Andresen”. In: Estudos Portugueses e Africanos, n. 7. São Paulo, 1986, p. 128.

${ }^{282}$ PAZ, Octavio. O arco e a lira, Tradução de Olga Savary. Rio de Janeiro: Nova Fronteira, 1982, p. 234.

${ }^{283}$ Ibidem, p. 217.

${ }^{284}$ Ibidem, p. 217.
} 
quanto as terríveis entidades que as representam: as Fúrias. Mas ao mesmo tempo, são sentimentos tão presentes, tão atuais, mesmo quando fingimos, neste mundo tão contemporaneamente virtual, que a morte seja algo superficial. Ao incorporar imagens contraditórias, o poema revela o lado sombrio, transgressor e complexo da nossa condição humana.

A poesia de Sophia Andresen acolhe não só o dia, a claridade e a razão, mas também a noite, escuridão, a angústia, a transgressão e a violência da morte. Sendo assim, confirmam a frase de Octavio Paz, que diz que o poema nos faz recordar o que esquecemos: o que somos realmente ${ }^{285}$.

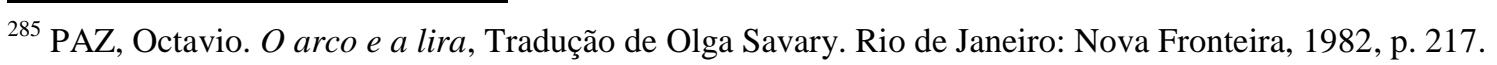




\section{O DEIXAR A CASA}

Este trabalho tinha, como objetivo, analisar as implicações que as variadas imagens do mito de Thânatos (a Morte) assumiam na poesia de Sophia Andresen, a partir da escolha de um determinado corpus de poemas. Apesar das diversas possibilidades que o tema nos proporcionou, chegamos a um ponto fundamental que norteia a poesia andresiana: a constatação, por parte do sujeito, da presença absoluta e concreta da morte no dia-a-dia da vida. Para tal, também foram observados textos de alguns helenistas e filósofos preocupados com essa questão tão antiga, que é o mistério da morte para o ser humano.

No seu diálogo com o mundo clássico, com o grego mais intensamente, é possível levantar alguns pontos: primeiro, que a poesia de Sophia Andresen, em sua relação constante com a cultura clássica, não apresenta nenhuma intenção de retorno a algum modelo poético grego na regularidade da forma estética. A Grécia, que surge na obra de Sophia Andresen, é construída principalmente através do olhar e de um escutar atentos às coisas.

Optamos por selecionar algumas imagens, entre as mais variadas possíveis, que Thânatos assume na obra de Sophia Andresen. Chega-se, assim, a um determinado número de imagens que refletem a presença da morte: no primeiro capítulo, foram as figuras míticas do Tempo (Cronos) e Memória (Mnemosýne); no segundo, a figura da Noite (Nýx) e, no terceiro capítulo, a Ira (Lýssia). Como um "polvo" invertebrado (figura com quem muitas vezes nos deparamos nos poemas andresianos), esse primeiro grupo de imagens desdobrou-se em vários outros sub-grupos, como por exemplo o "jardim", a "casa", o "Minotauro", as "Fúrias" e algumas personagens da tragédia grega, como Electra, Medeia e Clitemnestra, entre outras. 
No primeiro capítulo, pudemos perceber que a poesia de Sophia Andresen, apesar da luminosidade apolínea, também abarca espaços banhados por sombras, implicando uma atmosfera às vezes melancólica e nostálgica. A respeito de seu aprendizado com a cultura grega, a poeta diz: "A Claridade grega é uma claridade que reconhece a treva e a enfrenta.",286

No primeiro capítulo, temos a ação contínua e incessante do fluir do Tempo e todos os efeitos que esta ação suscita: a percepção da morte no passar do tempo, a idealização da infância e da juventude como espaços especiais e sacralizados e, por fim, a constatação e repulsa da terrível decomposição que o corpo sofre, tanto pelo passar do tempo, quanto pela morte. Há o embate de uma poesia que procura uma união eterna entre as coisas e a confirmação da finitude das mesmas.

A poeta compara o tempo linear a um terrível monstro que, de repente, salta por sobre o sujeito. No ato inesperado do saltar, está inscrito o engendrar do dia-a-dia da nossa própria morte, bem como o desconhecimento do quando ela acontecerá. "Terrível monstro" porque, apesar de todo o conhecimento que adquirimos, a morte é ainda o nosso pior medo. Esse Tempo cruel com seus mais variados efeitos encontra-se nestes versos do poema "Tempo", presente em do Livro Sexto, de 1962: “Tempo sem amor e sem demora / Que de mim me despe pelos caminhos fora". O sujeito tem plena consciência da sua fatalidade que é tecida nos limites do tempo: "a e hora da minha morte aflora lentamente / cada dia preparada."287 Joaquim Manuel Magalhães, no livro Rima pobre, sobre o questionamento da finitude e da tentativa de escapar ao desgaste do tempo, presente nos poemas andresianos, diz: "Todavia, ao lermos os seus poemas, mesmo os mais directamente ao serviço do "dia" e do "efêmero",

\footnotetext{
${ }^{286}$ ANDRESEN, Sophia de Mello Breyner. O nu na antiguidade clássica. Lisboa: Caminho, 1992, p. 23.

${ }^{287}$ Idem. Livro Sexto. Lisboa: Caminho, 2003, p.40.
} 
somos confrontados com uma resistência ao desaparecimento das paixões que teriam conduzido ao "tema" $[\ldots]$ ",288.

Da experiência com o real, temos o marcante poema "Meditação do Duque de Gandia sobre a morte de Isabel de Portugal". Constata-se que, mesmo valores absolutos como a beleza e o amor também estão submetidos à finitude da morte. Tudo, no mundo, é transitório e ilusório, tudo muda a todo momento. Daí a necessidade de se eternizar o instante: "É porque cada instante em mim foi vivo / na luta por um bem definitivo / Em que as coisas de amor se eternizassem",289.

A outra imagem ligada à figura do Tempo é a personagem mítica da Memória (Mnemosýne). A ela se relacionará a figura da casa como espaço, onde as lembranças e todas as ausências ganham abrigo, como verificamos nestes versos: A antiga casa que os ventos rodearam / Com suas noites de espanto e de prodígio"290.

Mostra-se oportuno lembrar o que Gaston Bachelardno livro A Poética do Espaço diz sobre a figura da casa:

\footnotetext{
Quando, na nova casa retornam as lembranças das antigas moradias transportamonos ao país da Infância Imóvel, imóvel como o Imemorial. [...] As lembranças do mundo exterior nunca há de ter a mesma tonalidade das lembranças da casa. Evocando as lembranças da casa, adicionamos valores de sonho. ${ }^{291}$
}

A imagem da casa também é local que concentra as memórias de tempos passados, principalmente os da infância. Aqui, simboliza o vazio do peso de ausências afetivas, sempre cercado dos sentimentos de solidão e melancolia: "A noite reúne a casa e o seu silêncio / [...]

\footnotetext{
${ }^{288}$ MAGALHÃES, Joaquim Manuel. Rima pobre. Lisboa. Presença, 1999, p. 41.

289 ANDRESEN, Sophia de Mello Breyner. Poesia. Lisboa: Caminho, 2005, p. 32.

290 Ibidem, p. 51.

${ }^{291}$ BACHELARD, Gaston. A poética do espaço. Traduzido por Antonio de Pádua Danesi. São Paulo: Martins Fontes, 2000, pp. 25-26.
} 
O vazio caminha em seus espaços vivos" (“A Noite e a Casa”), “A casa jaz com mil portas abertas / O interior dos armários é obscuro e vazio" ("Portas da Vila). Há também metáfora do palácio /labirinto, ligada à infância do eu lírico, como espaço de espanto e fascínio: "Era um dos palácios do Minotauro / - O da minha infância para mim o primeiro"292 (“O Palácio”); “[...] O passado é labirinto"293 (“Landgrave ou Maria Helena Vieira da Silva”).

Outro aspecto importante a ser lembrado é a intenção do sujeito em trazer para o poema o seu mundo interior, na tentativa de protegê-lo da ação maléfica do tempo, como verificamos na análise feita no primeiro capítulo com os versos de "No poema" presente em Livro sexto, de 1962: “Transferir o quadro o mudo a brisa / A flor o copo o brilho da madeira / [...] Para o mundo do poema limpo e rigoroso" 294 .

Vimos também que a memória, ao mesmo tempo em que revela, desvela, mergulhando as coisas nas sombras do esquecimento. Para lembrarmos e entrarmos em contato com “outro" mundo, o passado, é necessário esquecer-se do presente. Porém, esse passado que o eu lírico traz é completamente atravessado pela subjetividade do sujeito ao resgatá-lo e reescrevê-lo.

No segundo capítulo, o elemento ligado à Thânatos é a figura mítica da Noite (Nýx). Em seu aspecto físico, com o cair da escuridão e a consequente diminuição da visão, torna-se espaço maravilhoso e fantasmagórico. A representação do jardim noturno pode comportar uma imagem idílica, como também espaço de tensão, com sua vegetação abundante, algumas vezes sufocante, local onde o elemento onírico tem morada.

\footnotetext{
${ }^{292}$ ANDRESEN, Sophia de Mello Breyner. O nome das coisas. Lisboa: Caminho, 2004, p. 21.

${ }^{293}$ Idem. Dual. Lisboa: Caminho, 2004, p. 39.

${ }^{294}$ Idem. Livro sexto. Lisboa: Caminho, 2003, p. 32.
} 
Em alguns poemas andresianos temos a presença mítica da "Grande Noite”, idealizada pelo eu lírico como espaço mágico para a união com todas as coisas, como no poema que foi analisado no segundo capítulo, "O Jardim e a Noite": "Ó grande noite"295.

A noite também é espaço de sentimentos como solidão, melancolia e medo, como vimos nos poemas "Noites das Coisas" 296 e "Noites Sem Nome"297. Silenciosa, ela encobre a todos e a tudo. A imagem da "Grande Noite" também é associada à perda dos limites. O infinito que se abre aos olhos do sujeito possibilita a liberdade de qualquer demarcação e restrição, e faz nascer o desejo de união com as coisas, como verificamos na análise de alguns versos do poema “Luar", do livro Mar novo, de 1958:

Toma-me ó noite em teus jardins suspensos

Em teus pátios de luar e de silêncio

Em teus adros de vento e solidão"298

O sujeito, no poema "Floresta", do livro Dia do mar, de 1947, pode ter uma experiência muito próxima do que poderia ser a morte, a partir de uma vivência do espaço noturno: "Entre o terror e a noite caminhei / [...] Não ao redor das coisas mas morrendo"299;

Maria João Borges ${ }^{300}$ aponta para um caráter negativo que a experiência decorrente da morte dos outros acarreta na poesia andresiana, o que expõe as lacunas e o fracasso existente na aliança existente entre todas as coisas. A noite, portanto, em vez de ser fecunda, demonstra-se esvaziada. É a noite da negação, como, por exemplo, no poema "Nocturno da Graça" do livro Mar novo, de 1958: "Numa noite insone / De luzes fluorescentes / Numa

\footnotetext{
295 ANDRESEN, Sophia de Mello Breyner, Poesia, Lisboa: Caminho, 2005, p. 15.

296 Ibidem, p. 22.

297 Ibidem, p. 24.

298 ANDRESEN, Sophia de Mello Breyner. Mar novo. Lisboa: Caminho, 2003, p. 54.

${ }^{299}$ Idem. Dia do mar. Lisboa: Caminho, 2003, p. 64.

${ }^{300}$ BORGES, Maria João. Em torno do conceito de Poesia pura, Cinatti, Sophia e Eugênio de Andrade. Lisboa: Faculdade de Letras da Universidade de Lisboa, 1996, p. 311.
} 
noite cega surda presa"301 A noite pode adquirir uma conotação perigosa, estranha, assustadora em que a aliança não pode ser concretizada: "Esta é a noite / Densa de chacais / Pesada de amargura"302 (Mar novo, 1958).

A imagem da noite na poesia de Sophia Andresen, como verificamos, também pode ser um ambiente propenso a um doloroso questionamento humano, espaço de indecisão, de terror e espanto.

No capítulo três foram analisados alguns poemas em que se apresentou a imagem mítica das Fúrias e os sentimentos fortes como medo, ira e sede de vingança que elas inspiram.

Em alguns poemas, surgem também os monstros internos do ser humano, amorfos e sem contorno, tirados do caos e trazidos para a luz. O primeiro foi o Minotauro, que nos ensina sobre a violência latente que existe em cada um de nós. Através desse antigo mito desvela-se nossa parte de escuridão. O poema "O Minotauro", do livro Dual, fala exatamente deste outro lado sombrio do qual somos feitos: "Mas no sol dos ${ }^{303}$ meus pátios vazios / A fúria reina intacta / E penetra comigo no interior do mar".

Verificamos que a violência (Bía, em grego) também estava ligada às imagens das Mênades e das Fúrias. Estas últimas ganharam um espaço maior ao estarem presentes em outras figuras marcantes da dramaturgia grega, como Clitemnestra, Electra, Hécate e Medeia.

Ao lidar com sentimentos tão intensos e conflitantes, quer sejam estes trabalhados pelo próprio poema em deslocamento total do eu lírico, quer na assunção da sua voz, estamos diante de nosso caráter humano. Como Joaquim Manuel Magalhães ressaltou, em seu ensaio,

\footnotetext{
${ }^{301}$ ANDRESEN, Sophia de Mello Breyner, Mar Novo, Lisboa, Caminho, 2003, p. 53.

302 Ibidem, p. 53

${ }^{303}$ Idem. Dual. Lisboa: Caminho, 2004, p. 57.
} 
a poesia andresiana, ao retratar as Fúrias, trouxe para o poema um princípio trágico que conseguiu captar:

O salto sociológico que Sophia propõe consiste em discernir nas subversões à humanidade à humilde paz quotidiana as suas vinganças sobre o homem. Construindo um mundo sem atenção à própria humanidade do homem, o homem torna-se vítima de si mesmo. E de novo se encontra sem refúgio. ${ }^{304}$

“Marinheiros Sem Mar” é outro poema que, ao tratar de um tema complexo, também apresenta uma despersonalização do sujeito lírico. Este parte da transgressão de um marinheiro e das variadas formas de expiação pela qual terá que passar, como castigo. É possível perceber certo prazer no processo todo.

O mesmo podemos dizer dos dois poemas que retratam Electra e a sua sede de vingança. A fúria de Electra faz com que ela, dia e noite, seja a lembrança viva do assassinato do pai e uma vingadora feroz, que não descansa enquanto não vingar com sangue a sua morte pelas mãos de Clitemnestra.

O elemento divino, presente nesses poemas, mesmo que possuam uma função estritamente estética, trazem um antigo princípio em que a dor e a ameaça de morte fazem parte dos rituais religiosos. Ao mesmo tempo em que há um senso de medo e de mal diante de forças tão intensas e desconhecidas (como, no caso, a morte), no seu sentido contrário há também, inevitavelmente, sentimentos de fascínio e atração, que impulsionam o sujeito para a beira do abismo. A poesia andresiana alimenta-se desta ambiguidade entre luz e trevas, como podemos verificar no poema "Labirinto" presente em Livro Sexto de 1962: "Sozinha caminhei no labirinto / Aproximei meu rosto do silêncio e da treva / Para buscar a luz de um dia limpo",305.

\footnotetext{
${ }^{304}$ MAGALHÃES, Joaquim Manuel. Rima pobre. Lisboa: Presença, 1999, p. 43.

305 ANDRESEN, Sophia de Mello Breyner. Livro sexto. Lisboa: Caminho, 2003, p. 39.
} 
Na sua interação com o mito, como diz Alberto Lacerda, a poeta cria uma mitologia própria, pois: “[...] apesar da presença do mito que o poder do poeta lhes transmito, o mar, o vento, os pássaros, a noite os jardins - não deixam de ser menos reais." 306

As sociedades antigas eram extremamente guerreiras. No convívio com a morte, descobriram desde cedo quão verdadeira e absoluta é a finitude do ser humano. Os efeitos do passar do tempo também eram motivos de angústias por parte do homem grego que via na beleza do corpo uma representação do divino.

Sophia Andresen, no ensaio $O$ nu na antiguidade clássica $^{307}$, aponta a ambiguidade existente na relação entre o homem e o divino: "Por isso na escultura grega se insinua uma luz de praia. [...] A carnalidade é radiosa, imanente à luz. Mas a relação da vida humana com a felicidade divina é ambígua e complexa." Para o eu lírico, os efeitos do passar do tempo e a decomposição do corpo são verdades extremamente cruéis. No contato com realidades tão duras o sujeito descobre de forma dolorosa a lição de que todas as coisas estão sob o jogo do tempo e que este traz em si a verdade absoluta da morte.

Talvez seja o convívio intenso com a violência da morte um dos motivos para que o homem clássico e, principalmente o grego, valorizasse tanto a beleza, tentando aproveitá-la ao máximo, expressando-a seja na forma da estatuária e da poesia, como do teatro.

Hoje em dia vivemos uma situação um tanto quanto oposta à do homem clássico e à visibilidade da morte. A morte pode ter dois aspectos ambíguos para a nossa sociedade: banalizada virtualmente através dos meios de comunicação ou oculta nos quartos de hospitais, UTI, longe de nossas casas e de nossos olhos. Nos dois sentidos há uma anestesia em relação

\footnotetext{
${ }^{306}$ LACERDA, Alberto. "Sophia de Mello à cerca da sua poesia". In: Távola Redonda - Folhas de Poesia n. 07. Porto: 1950.

${ }^{307}$ ANDRESEN, Sophia de Mello Breyner. O nu na antiguidade clássica. Lisboa: Caminho, 1992, p. 22.
} 
ao seu real poder. Segundo Mauro Maldonato, nossa civilização se priva do contato com esta, desviando os olhos para tal existência. Ele diz:

Os homens procuraram escapar da atração da morte, do fim, construindo civilizações que os mantivessem ocupados na fúria dos negócios, andando depressa, como cada um de nós pode ver naqueles lugares mortais que são as grandes cidades. [...] A civilização contemporânea, portanto, recalca e oculta a morte. Como, aliás, recalca e oculto todo discurso que a ela alude. Embora muitas neuroses individuais carreguem o selo inconfundível da angústia da morte, é no "mal-estar na civilização" que seu poder se expressa, como demonstrou Freud ${ }^{308}$

Percebe-se que a imagem da morte na poesia de Sophia Andresen também tem a função de tirá-la das sombras, iluminando-a através da beleza e do lirismo que a linguagem poética comporta. Ernst Cassirer, no livro Ensaio sobre o homem, analisa a beleza de uma obra de arte:

Em sentido estrito, porém, a beleza de uma obra de arte nunca é "fácil". O gozo da arte não tem origem em um processo de suavização ou de relaxamento, mas de intensificação de todas as nossas energias. [...] Um grande poeta lírico tem o poder de dar uma forma definida aos nossos sentimentos mais obscuros. ${ }^{309}$

Desvelar nossa face mais sombria é humanizar-nos. Maurice Blanchot em $O$ Espaço

Literário fala desta relação de poder entre a morte e a arte de Kafka :

Por que a morte? Porque ela é o extremo, Quem dispõe dela, dispõe extremamente de si, está ligado a tudo o que pode, é integralmente poder. A arte é senhora do momento supremo, é senhora suprema. 310

No poema "Sinto os Mortos" do livro Poesia de 1944 através do contato intenso com a morte há a possibilidade de um aprendizado:

$[\ldots]$

E sei que trago em mim a minha morte.

\footnotetext{
${ }^{308}$ MALDONATO, Mauro. A subversão do ser. Tradução de Luciano Loprete e Roberta Barni. São Paulo: Peirópolis, 2001, p. 147.

${ }^{309}$ CASSIRER, Ernst. Ensaio sobre o homem. Tradução de Tomás Rosa Bueno. São Paulo: Martins Fontes, 2005, p.269-272.

${ }^{310}$ BLANCHOT, Maurice. O espaço literário. Tradução de Álvaro Cabral. Rio de Janeiro: Rocco, 1987, p. 87.
} 
Mas perdi o meu ser em tantos seres,

Tantas vezes morri a minha vida,

Tantas vezes beijei os meus fantasmas,

Tantas vezes não soube dos meus actos

Que a morte será simples como ir

Do interior da casa para a rua. ${ }^{311}$

Nos versos do poema há uma intensificação do contato entre o eu lírico e a morte. Ao lançá-la para o espaço corriqueiro de nosso dia-a-dia, o sujeito procura suavizar seu teor assustador e violento. Através do eufemismo presente nos versos (“que a morte será simples como ir / do interior da casa para a rua") e ao torná-la íntima, tenta fazer com que quando esta chegue, não exista rejeição, estranhamento ou medo, porém acolhimento. E em um movimento contrário de sua chegada, o eu lírico "deixa o interior da casa para rua". Como diz Eduardo Prado Coelho, diz que este ato do eu lírico provoca um "tecer incessante" que "a entrelaça em nós" e tudo é "tão quotidiano e evidente" que a morte "se insinua na trama da vida sem aparente choque ou violência".

Porém, o eu lírico sabe de sua difícil e bela missão e não a renega. O destino, a solidão, a fúria, a morte, revelações de aspectos outros de nossa própria face que o poeta ao mergulhar no caos das trevas desvela para a luz, como nos diz o poema "O poeta Trágico" presente no livro Dual de 1972:

\author{
No princípio era o labirinto \\ O secreto palácio do terror calado \\ Ele trouxe para o exterior o medo \\ Disse-o na lisura dos pátios no quadrado \\ De sol de nudez e de confronto \\ Expôs o medo como um touro debelado ${ }^{312}$
}

Os versos do poema falam da consciência por parte do eu lírico de sua missão. É o registro de um esforço intenso na luta para escapar ao "labirinto" interno, ao terror que nos

\footnotetext{
311 ANDRESEN, Sophia de Mello Breyner. Poesia. Lisboa: Caminho, 2003, p. 59.

312 Idem. Dual. Lisboa: Caminho, 2004, p. 60.
} 
cala, ao medo que nos imobiliza. Mas o exorcizar e o transcender destas forças sombrias só podem ocorrer, como o eu lírico diz, a partir da magia, da beleza que há na arte da palavra poética, "Disse-o...". Assim, "na lisura dos pátios no quadrado / De sol de nudez e de confronto", ele pode reduzir e tornar nulo o medo, "como um touro debelado". 


\section{BIBLIOGRAFIA:}

ALEGRE, Manuel. Perto da pulsação inicial. In: Jornal de Letras, Arte e Ideias, Lisboa, 1999.

ALMEIDA, Rogério Miranda de. Eros e Tanatos: a vida, a morte, o desejo. São Paulo: Edições Loyola, 2007.

AMARAL, Fernando Pinto do. A aliança quebrada. Jornal de Letras, Artes e Ideias. Lisboa, 1999.

ANDRESEN, S. de M. B. A árvore. Porto: Figueirinhas, 1985.

A fada Oriana. Lisboa: Ática, 1958.

A floresta. Porto: Figueirinhas, 1968.

. A menina do mar. Lisboa: Ática, 1958.

A noite de natal. Lisboa: Ática, 1959.

. Contos exemplares. Lisboa: Livraria Morais Editora, 1962.

. Coral 5 ${ }^{\mathrm{a}}$. ed. Lisboa: Caminho, 2005.

. Dia do Mar 5 ${ }^{\mathrm{a}}$. ed. Lisboa: Caminho, 2003.

Dual ed. definitiva Lisboa: Caminho, 2004.

. Geografia ed. definitiva Lisboa: Caminho, 2004. 
Histórias da terra e do mar. Lisboa: Edições Salamandra, 1984.

. Ilhas ed. definitiva Lisboa: Caminho, 2004.

. Livro Sexto ed. definitiva Lisboa: Caminho, 2003.

. Mar Novo edição definitiva Lisboa: Caminho, 2003.

. Musa ed. revista Lisboa: Caminho, 2004.

. Navegações ed. definitiva Lisboa: Caminho, 2004.

. No Tempo Dividido 4a ${ }^{\mathrm{a}}$ ed. Lisboa: Caminho, 2005.

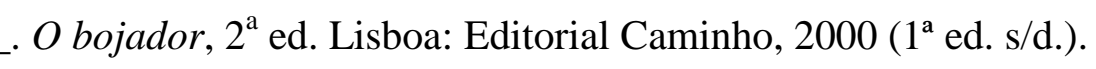

. O Búzio de Cós e outros poemas 3 $3^{\mathrm{a}}$. ed. Lisboa: Caminho, 1999.

. O cavaleiro da Dinamarca. Porto: Figueirinhas, 1964.

. O colar. Lisboa: Editorial Caminho, 2001.

. O Nome das Coisas ed. definitiva Lisboa: Caminho, 2004.

. O Nu na Antiguidade Clássica 3 ${ }^{\mathrm{a}}$. ed. Lisboa: Caminho, 1992.

O rapaz de bronze. Lisboa: Minotauro, 1965.

Poesia 5 ${ }^{\mathrm{a}}$. ed. Lisboa: Caminho, 2005.

ARENDT, Hannah. O Conceito de Amor em Santo Agostinho. Tradução de Alberto Pereira Dinis. Lisboa: Instituto Piaget, 1997. 
AZEVEDO, Luis Carlos de Moura. O quarto: figuração do intimismo na poesia de Sophia de Mello Breyner Andresen. Dissertação de Mestrado de Universidade São Paulo. São Paulo, 2007.

BACKES, Karin Lilian Hagemann. Mar de Poeta - A Metáfora do Oceano nas Líricas de Cecília Meireles e Sophia Andresen. Tese de doutorado da Pontifícia Universidade Católica Rio Grande do Sul. Porto Alegre, 2008.

BACHELARD, Gaston. A Poética do Espaço. Tradução de por Antonio de Pádua Danesi. SãoPaulo: Martins Fontes, 2000.

BARBOSA, Márcia. Sophia Andresen: leitora de Camões, Cesário Verde e de Fernando Pessoa. Passo Fundo: Universidade de Passo Fundo, 2001.

BARRENTO, João. O arco da palavra: ensaios. São Paulo: Escrituras, 2006. Sophia Substantiva. In: Mil Folhas - Público. Lisboa, 2004, p. 25. Um quarto de século de poesia portuguesa. In: Semear, n. 4. Rio de Janeiro: 2000 .

BATAILlE, Georges. O Erotismo. Tradução de Antonio Carlos Viana. Porto Alegre: L \& PM, 1987.

BELCHIOR, Maria de Lourdes. Itinerário poético de Sophia. In: Colóquio-Letras, n. 89. Lisboa, 1986, p. 36-42.

BELLINE, Ana Helena Cizotto. Mito e História na Obra Poética de Sophia de Mello Breyner Andresen. In: Estudos Portugueses e Africanos, n. 7. São Paulo, 1986, p. 121 a 139. 
BENJAMIN, Walter. Obras Escolhidas Magia, Arte e Política. Tradução de Sérgio Paulo Rouanet. São Paulo: Brasiliense, 2010.

BLANCHOT, Maurice. A Conversa Infinita - 1 A Palavra Plural (Palavra de Escrita). Tradução de Aurélio Guerra Neto. São Paulo: Escuta, 2001.

A parte do fogo. Tradução de Ana Maria Scherer. Rio de Janeiro:

Rocco, 1997.

O espaço literário. Tradução de Álvaro Cabral. Rio de Janeiro:

Rocco, 1987.

BOECHAT, Virgínia Bazzetti. Na rota das navegações. Sophia de Mello Breyner Andresen.

Rio de Janeiro: Pontifícia Universidade Católica do Rio de Janeiro, agosto de 2004.

BORGES, Maria João. A Poesia de Sophia: Orientatio, Iniciação. In: Em torno do conceito de "poesia pura": Cinatti, Sophia e Eugênio de Andrade. Universidade de Lisboa, 1996.

BOSI, Alfredo. O ser e o tempo da poesia. São Paulo: Cultrix, 1993.

BRANDÃO, Junito de Souza. Dicionário Mítico-Etimológico da Mitologia Grega. Volume I

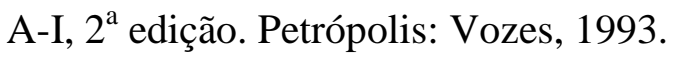

Dicionário Mítico-Etimológico da Mitologia Grega. Volume

II J-Z, Petrópolis: Vozes, 1992.

. Mitologia Grega. Volume I, $8^{\mathrm{a}}$ edição. Petrópolis: Vozes, 1993.

. Mitologia Grega. Volume II, 6 ${ }^{\mathrm{a}}$ edição. Petrópolis: Vozes, 1995. 
Mitologia Grega. Volume III, $14^{\mathrm{a}}$ edição. Petrópolis: Vozes, 2007.

BRUNEL, Pierre. (org.). Dicionário de mitos literários. Tradução de Carlos Sussekind, Jorge Laclette, Maria Thereza Rezende Costa e Vera Whately. Rio de Janeiro: José Olympio, 2000.

BUESCU, Helena Carvalhão. Poesia e realidade. In: Jornal de Letras, Artes e Ideias. Lisboa: 21 de março de 2001.

BURKERT, Walter. Religião Grega na Época Clássica e Arcaica. Tradução de M. J. Simões Loureiro. Lisboa: Fundação Calouste Gulbenkian, 1993.

CALASSO, Roberto. A literatura e os deuses. Tradução de Jônatas Batista Neto. São Paulo:

Companhia das Letras, 2004.

CAMPOS, Haroldo de. O Arco-Íris Branco Ensaios de Literatura e Cultura. Rio de Janeiro: Imago, 1997.

CARMO, José Palla e. Ficção narrativa e alegoria: "Contos Exemplares”, de Sophia de Mello Breyner Andresen. In: Do Livro à Leitura. Lisboa: Europa-América, 1971.

CASSIRER, Ernst. A Filosofia das Formas Simbólicas II - O Pensamento Mítico. Tradução de Cláudia Cavalcanti. São Paulo: Martins Fontes, 2004.

- Ensaio sobre o homem: introdução a uma filosofia da cultura humana. Tradução de Tomás Rosa Bueno. São Paulo: Martins Fontes, 1997.

. Linguagem e Mito. $4^{\mathrm{a}}$ edição. Tradução de J. Guinsburg e Miriam Schnaiderman. São Paulo: Perspectiva, 2006. 
CHEVALIER, Jean; GHEERBRANT, Alain. Dicionário de símbolos. Tradução de Vera da Costa e Silva, Raul de Sá Barbosa, Angela Melim, Lúcia Melim. Rio de Janeiro: Ed. José Olympio, 2008.

CEIA, Carlos. Iniciação aos mistérios da poesia de Sophia de Mello Breyner Andresen. Lisboa: Vega, 1996.

. Monólogo Crítico - Nos 50 anos de vida literária de Sophia de Mello Breyner Andresen. In: Colóquio Letras n. 132-133. Lisboa, 1994, p. 184-187. . O estranho caminho de Delphos. Lisboa: Vega, 2003.

COELHO, Eduardo Prado. A respiração azul das coisas. In: Mil Folhas - Público. Lisboa, 2004, p. 10-11. . O real, a aliança e o excesso na poesia de Sophia de Mello Breyner Andresen. In: A Palavra Sobre a Palavra. Porto: Portucalense, 1972, p. 225-232. . "Sophia, a lírica e a lógica”. In: Colóquio Letras, n. 57, Lisboa, 1980, p. 20-35. . Sophia de Mello Breyner Andresen fala a Eduardo Prado Coelho. In: Revista ICALP n. 6, 1986. . Sophia. Público, 14 de junho de 1999.

COELHO, Jacinto Prado. Sophia de Mello Breyner Andresen: contos exemplares. In: Colóquio-Letras, n. 58. Lisboa: abril de 1970.

COSTA, Alexandre. Heráclito, fragmentos contextualizados. Rio de Janeiro: DIFEL, 2002. 
CUNHA, António Manuel dos Santos. Sophia de Mello Breyner Andresen: Mitos Gregos e Encontro com o Real. Lisboa: Imprensa Nacional - Casa da Moeda, 2004.

DIEL, Paul. O Simbolismo na Mitologia Grega. Tradução de Roberto Cacuro e Marcos Martinho dos Santos. São Paulo: Attar, 1991, p. 34.

DUARTE, Adriane da Silva. “Civilização e Barbárie em Medéia”. In: Jornal O Estado de São Paulo. Ano VIII, n. 584, 1991, p. 4.

ELIADE, Mircea. O Sagrado e o Profano: a essência das religiões. Tradução de R. Fernandes, São Paulo: Martins Fontes, 1922.

ÉSQUILO. Agamêmnon. Tradução de JAA Torrano. São Paulo: Iluminuras, 2004.

. Coéforas. Tradução de JAA Torrano. São Paulo: Iluminuras, 2004.

. Eumênides. Tradução de JAA Torrano. São Paulo: Iluminuras, 2004.

. Orestéia - Agamémnon, Coéforas, Euménides. Tradução de Manuel de Oliveira

Pulquério. Rio de Janeiro: Edições 70, 1992.

EURÍPIDES. Alceste. Tradução de Junito de Souza Brandão. Rio de Janeiro: Bruno Buccini, 1968.

. Electra. In: Electra(s). Tradução de Trajano Vieira. Cotia: Ateliê Editorial, 2009.

Ifigénia em Áulide. Tradução de Carlos Alberto Pais de Almeida. Coimbra:

Fund. Calouste Gulbenkian, s/d.

Íon. Tradução de Frederico Lourenço. Lisboa: Colibri, s/d. 
. Medeia. Traduzido por Sophia de Mello Breyner Andresen. Lisboa: Caminho, 2006. Medéia. Tradução de JAA Torrano. São Paulo: Hucitec, 1991.

FIALHO, Maria do Céu Zambujo. Luz e Trevas no Teatro de Sófocles, Coimbra: Universidade de Coimbra, 1992.

FOLEY, Helene P. Female Acts in Greek Tragedy. New Jersey: Princeton University Press, 2003.

FREUD, Sigmund. Além do princípio de prazer. Tradução de Christiano Monteiro Oiticica. Rio de Janeiro: Imago, 2003.

GASTÃO, Cruz. “Sophia de Mello Breyner Andresen - Dual”. In: Poesia Portuguesa Hoje. Lisboa: Plátano, 1973, p. 107-110.

GIRARD, René. A Violência e o Sagrado. Tradução de Martha Conceição Gambini. São Paulo: Universidade Estadual Paulista, 1990.

GOUlART, Rosa Maria. “O Poema de Sophia: 'Como se os Deuses o Dessem”". In: $O$ Escritor n. 4. Braga, 1994.

GUERREIRO, António. “Mares e Poemas de Sophia”. In: Jornal Expresso, Lisboa, 1998.

GUIMARÃES, Fernando. A poesia contemporânea portuguesa do Final. Dos Anos 50 aos Anos 90. Vila Nova de Famalicão: Quasi, 2002.

. "Imaginação e Intelectualização Rui Cinatti, Sophia Andresen, Eugênio de Andrade, e Jorge de Sena”. In: Linguagem e Ideologia. Porto: Lello: 1996. 
Os Problemas da Modernidade. Lisboa: Editorial Presença, 1994.

HELDER, Herberto. "Paradiso um pouco". In: Mil Folhas - Público. Lisboa, 2004, p. 12.

HESÍODO. Os Trabalhos e os Dias. Tradução de Mary de Camargo Neves Lafer. São Paulo: Iluminuras, 2008.

. Teogonia: a origem dos deuses. Tradução de JAA Torrano. São Paulo: Iluminuras, 1992.

HOMERO. Ilíada, Tradução de Carlos Alberto Nunes. Rio de Janeiro: Ediouro, 1996. . Odisséia. Tradução de Carlos Alberto Nunes. Rio de Janeiro: Ediouro, 2004.

HORTA, Maria de Lurdes. Poetas portugueses contemporâneos. Recife: Pirata, 1985.

KLOBUCLA, Anna. “Sophia escreve Pessoa”. In: Colóquio Letras n. 140/141. Lisboa, 1996, p. $157-176$.

KRISTEVA. Sol negro, depressão e melancolia. Tradução de Carlota Gomes. Rio de Janeiro: 1989.

KURY, Mário da Gama, Dicionário de Mitologia Grega e Romana. $5^{\text {a }}$ edição. Rio de Janeiro: Jorge Zahar Editor, 1999.

LACERDA, Alberto de. "Sophia de Mello Breyner Andresen, à cerca da sua poesia". In: Távola Redonda - Folhas de Poesia n. 07. Porto, 1950, s/p.

LEMOS, Virgílio de. Sophia: "Há forças de destruição na minha poesia". In: ler Livros \& Leitores n. 7, 1989, pp. 21-25. 
LEVY, Tatiana Salem. A experiência do fora: Blanchot, Foucault e Deleuze. Rio de Janeiro: 2003.

LOPES, Óscar. 'Sophia de Mello Breyner Andresen”. In: Os Sinais e os Sentidos: literatura portuguesa do século XX. Lisboa: Caminho: 1986, p. 107-112.

LOPES, Silvina Rodrigues. “A afirmação Silabada”. In: Jornal de Letras, Artes e Ideias. Lisboa, 2004, p. 11.

"Lugar do desejo inextinguível”. In: Mil Folhas - Público.

Lisboa, 2004, p. 14.

LOURENÇO, Eduardo. "Para um Retrato de Sophia". In: Sophia de Mello Breyner Andresen Antologia. Lisboa: Moraes Editores, 1975.

“Um Retrato de Sophia”. In: Mil Folhas - Público. Lisboa, 2004, p.

06-07.

LOURENÇO, Frederico. "Luz cor de amora". In: Mil Folhas - Público. Lisboa, 2004, p. 20. Poesia Grega de Álcman a Teócrito. Organização e tradução de Frederico Lourenço. Lisboa: Cotovia, 2006.

. "Uma Grécia Própria". In: Jornal de Letras, Artes e Ideias.

Lisboa, 2004, p. 11.

LOVECRAFT, H.P. O Horror Sobrenatural em Literatura. Tradução de Celso M. Paciornik. São Paulo: Iluminuras, 2008.

MAGALHÃES, Joaquim Manuel. "Sophia de Mello Breyner Andresen". In: Rima Pobre. Lisboa: Presença, 1999. 
MAIA, Maria. "Sophia de Mello Breyner Andresen, substantiva e concreta". In: Jornal de Poesia, Lisboa, 2000.

MALDONATO, Mauro. A subversão do ser. Tradução de Luciano Loprete e Roberta Barni. São Paulo: Peirópolis, 2001.

MALHADAS, Daisi. Tragédia Grega: O Mito em Cena. Cotia: Ateliê Editorial. 2003.

MARINHO, Maria de Fátima. A Poesia Portuguesa nos Meados do Século XX Rupturas e Continuidades. Lisboa: Caminho, 1989.

MARTINHO, Fernando J. B. "A poesia portuguesa depois de Pessoa". Contrastes n. 42. Outubro/novembro de 2005. Sophia lê Pessoa. In: Persona n. 7, Lisboa, 1982.

MARTINS, Guilherme D’Oliveira. “A Dignidade do Ser”. In: Jornal de Letras, Artes e Ideias. Lisboa, 2004, p. 13-14. . "Homenagem ao Porto". In: Jornal de Letras, Artes e

Ideias. Lisboa, 2001.

MEDINA, Cremilda de Araújo. “Sophia de Mello Breyner Andresen”. In: Viagem à literatura portuguesa contemporânea. Rio de Janeiro: Nórdica, 1983, p. 179-187.

MOURÃO-FERREIRA, David. "Sophia de Mello Breyner Andresen na Publicação de 'No Tempo Dividido"”. In: Vinte Poetas Contemporâneos, Lisboa: Ática, 1960.

NASO, Publio Ovidio. Trechos das Metamorphoses. Traduução de J. C. São Paulo: Livraria Saleziana, 1931. 
O’NEIL, Eugene. Electra Enlutada. Tradução de R. Magalhães Junior e Miroel Silveira. Rio de Janeiro: Edições Bloch, 1970.

OVÍDIO, Publio Nasão. Metamorfoses. Tradução de Bocage. Introdução João Angelo Oliva Neto. São Paulo: Hedra, 2000.

PAES, José Paulo. Poemas da antologia grega ou paladina. Organização e tradução de José Paulo Paes. São Paulo: Companhia das Letras, 2001.

PASSOS, Maria Armanda. “O poeta por trás da poesia”. In: Jornal de Letras, Artes e Ideias. Lisboa, 1999.

PAZ, Octávio. O Arco e a Lira. $2^{\mathrm{a}}$ edição. Tradução de Olga Savary. Rio de Janeiro: Nova Fronteira, 1982.

Os Filhos do Barro: Do Romantismo à Vanguarda. Tradução de Olga Savary. Rio de Janeiro: Nova Fronteira, 1984.

. Signos em Rotação. Tradução de Sebastião Uchoa Leite. São Paulo: Perspectiva, 1996.

PAZ, Sidônio. "Harmonia Perfeita”. In: Jornal de Letras, Artes e Ideias. Lisboa, 1999.

PEREIRA, Maria Helena Rocha. "Em volta das 'palavras aladas"”. In: Colóquio Letras n. 80. Lisboa, 1998, p. 35-48. Motivos clássicos na poesia portuguesa Contemporânea: o mito de Orfeu e Eurídice. Coimbra: Faculdade de Letras da Universidade de Coimbra, 1982. PESSOA, Fernando. Livro do Desassossego Por Bernardo Soares. Organização de Richard Zenith. São Paulo: Companhia das Letras, 2006. 
PLATÃO. O Banquete. Tradução de Carlos Alberto Nunes. Belém: UFPA, 2001.

PROUST, Marcel. Em Busca do Tempo Perdido, No Caminho de Swann. Volume I. Tradução de Mario Quintana. São Paulo: Globo, 2008.

RAGUSA, Giuliana. Fragmentos de Uma Deusa: a representação de Afrodite na lírica de Safo. São Paulo: UNICAMP, 2005.

REIS, Margarida Gil dos. "Um mundo só-lido? Visões do real na poesia de Herberto Helder e Sophia de Mello Breyner Andresen”. In: Revista Texto e Pretextos n. 1. Lisboa: Centro de Estudos Comparatistas da Faculdade de Letras da Universidade de Lisboa, 2002, p. 14-15.

RILKE, Rainer Maria. Os Poemas As Elegias de Duino e Sonetos a Orfeu. Tradução de Paulo Quintela. Porto: O Oiro do Dia, 1983.

ROCHA, Clara. "Nos 50 Anos de Vida Literária de Sophia. Sophia de Mello Breyner Andresen: poesia e magia". In: Colóquio Letras, n. 132/133. Lisboa, 1994.

ROCHA, Clara Crabbé. A Poesia de Sophia de Mello Breyner Andresen ou o Culto do Canto Mágico de Orfeu. Coimbra: Faculdade de Letras Universidade de Coimbra, s/d.

ROZÁRIO, Denira. Palavra de poeta Portugal. Rio de Janeiro: Civilização Brasileira, 1994.

SAFO. "Poemas e Fragmentos de Safo". In: Poesia e Prosa. Volume II. Tradução de Eugênio de Andrade. Lisboa: O Jornal, 1990.

SAINT-VICTOR, Paul de. As Duas Máscaras. Tradução de Gilson César Cardoso de Souza. São Paulo: Germape, 2003.

SCLIAR, Moacyr. Saturno nos Trópicos. São Paulo: Companhia das Letras, 2003.

SEIXO, Maria Alzira. Ética da Poesia. In: Jornal de Letras, Artes e Ideias. Lisboa, 2001. 
SERRA, José Pedro. Electra ou a voz do Hades. In: Lisboa MITE'06. Lisboa: <http://www.teatro-dmaria.pt/media/pdf/JORNAL_02_SITE.pdf.>. Acesso em 28.10.2010.

SHAKESPEARE, Willian. Hamlet, o príncipe da Dinamarca. Tradução de F. Carlos de Almeida Cunha Medeiros e Oscar Mendes. São Paulo: Victor Civita, 1981.

SILVA, Sofia Maria Sous. Reparar brechas: a relação entre as artes poéticas de Sophia de Mello Breyner Andresen e Adília Lopes e a tradição moderna. Tese de Doutorado. Rio de Janeiro: Pontifícia Universidade Católica, 2007.

. Sobre a paisagem em Sophia de Mello Breyner Andresen. São

Paulo: Universidade de São Paulo, 2008.

."Sobre Pessoa e Sophia". Revista Semear, n. 6, Rio de Janeiro. . Um viés da ética na obra de Sophia de Mello Breyner Andresen.

Tese de Mestrado. Rio de Janeiro: Pontifícia Universidade Católica, 2003.

SIMÕES, João Gaspar. Literatura, Literatura, Literatura... Lisboa: Portugália, 1964. . "Sophia de Mello Breyner Andresen". In: Crítica II - Poetas Contemporâneos (1946-1961). Lisboa: Delfos, 1963.

SNELL, Bruno. A Cultura Grega e as Origens do Pensamento Europeu. Tradução de Pérola de Carvalho. São Paulo: Perspectiva, 2001.

SÓFOCLES. Aias. Tradução de Fernando Ribeiro de Oliveira. São Paulo: Iluminuras, 2008. . Édipo Rei. $2^{\text {a }}$ edição. Tradução de Trajano Vieira. São Paulo: Perspectiva, 2009. 
Electra. In: Electra(s). Tradução de Trajano Vieira. Cotia: Ateliê Editorial, 2009.

Electra. Tradução de Mário da Gama Kury. Rio de Janeiro: Civilização Brasileira, 1965.

SOUSA, João Rui. “Dual”. In: Colóquio-Letras, n. 12. Lisboa, 1973, p. 85-86. . “Sophia de Mello Breyner Andresen - Navegações”. In: Colóquio Letras n. 77, Lisboa, 1984, p. 89-90.

VATTIMO, Gianni. A Sociedade Transparente. Tradução de Hossein Shooja e Isabel Santos. Lisboa: Relógio D’Água, 1992.

VIEIRA, Alice. “Evocação”. In: Jornal de Letras, Artes e Ideias. Lisboa, 2004, p. 22.

VERNANT, Jean-Pierre. Entre Mito e Política. Tradução de Cristina Murachco. São Paulo: EDUSP, 2002.

. Mito e pensamento entre os gregos. $2^{\mathrm{a}}$ edição. Tradução de Haiganuch Sarian. São Paulo: Editora Paz e Terra, 2002. Mito e religião na Grécia antiga. Tradução de Joana Angélica D’Avila. São Paulo: Martins Fontes, 2006.

O Universo Os Deuses Os Homens. $5^{\text {a }}$ reimpressão. Tradução de Rosa Freire d'Aguiar. São Paulo: Companhia das Letras, 2005.

VIDAL-NAQUET, Pierre. VERNAT, Jean-Pierre. Mito e tragédia na Grécia antiga. Tradução de Anna Lia A. de Almeida e Filomena Yoshie Hirata Garcia. São Paulo: Perspctiva, 2008. 
WILLIAMS, Raymond. Tragédia Moderna. Tradução de Betina Bischof. São Paulo: Cosac \& Naify, 2002.

WOOLF, Virginia. Mrs. Dalloway. Tradução de Mario Quintana. Rio de Janeiro: Nova Fronteira, 2006. 


\section{ANEXOS}

\section{ANEXO A - THÂNATOS}

Segundo Junito de Souza Brandão Thânatos tem como raiz o indo-europeu *dhwen, “dissipar-se, extinguir-se" e o sentido de "morrer" seria uma inovação do grego: "O morrer, no caso significa ocultar-se, ser como sombra, uma vez que na Grécia o morto tornava-se eídolon, um como que retrato em sombras, um "corpo insubstancial”313. Do ponto simbólico, Thânatos é aspecto perecível e destruidor da vida.

Segundo a Teogonia, do poeta Hesíodo, era filho de Nix (a Noite) e irmão de Hipnos (o Sono): "Noite pariu hediondo Lote, Sorte negra / e Morte, pariu Sono e pariu a grei de Sonhos" ${ }^{\text {314 }}$. Thânatos é descrito como uma divindade que tinha coração de ferro e entranhas de bronze. Hesíodo também descreve as diferenças entre ele e seu irmão Hipnos:

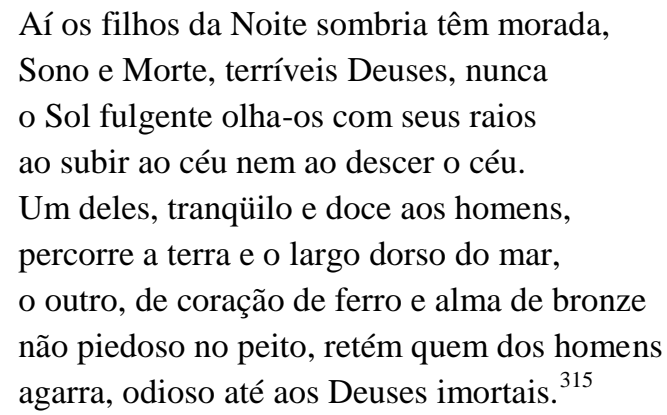

Thânatos não possui um mito propriamente seu. Na tragédia grega, surgiu como personagem pela primeira vez na obra de Frínico (século VI a.C.) ${ }^{316}$, mas, na realidade, só se afirmou a partir da tragédia de Eurípides, Alceste. Neste trecho do drama de Eurípides percebemos o quanto Thânatos incomodava os demais deuses:

THÂNATOS: De matar a quem devo? Pois este é o meu ofício. APOLO: Não! Mas de apressar a morte dos que tardam a morrer... THÂNATOS: Compreendo tuas razões e desejos. APOLO: Haveria um meio de Alceste chegar à velhice? THÂNATOS: Não. Fica sabendo que também eu gosto de honrarias.

\footnotetext{
${ }^{313}$ BRANDÃO, Junito de Souza. Mitologia Grega Vol. I, Petrópolis: Vozes, 1993, p. 225-226.

${ }^{314}$ HESÍODO, Teogonia, trad. JAA Torrano, São Paulo, Iluminuras, 1992, p. 117.

${ }^{315}$ HESÍODO, Teogonia, trad. JAA. Torrano, São Paulo, Iluminuras, 1992, p. 147-148.

${ }^{316}$ BRANDÃO, Junito de Souza. Mitologia Grega Vol. I, Petrópolis: Vozes, 1993, p. 226.

${ }^{317}$ EURÍPIDES, Alceste, trad. Junito de Souza Brandão, Rio de Janeiro, Bruno Buccini, 1968, p. 84-85.
} 
$\mathrm{Na}$ peça, Hércules descreve outras características de Thânatos momentos antes resgatar Alceste do Hades: "Irei espreitar Tânatos, soberano dos mortos, vestido de preto e penso surpreendê-lo no momento de beber, junto ao túmulo, o sangue das vítimas"318

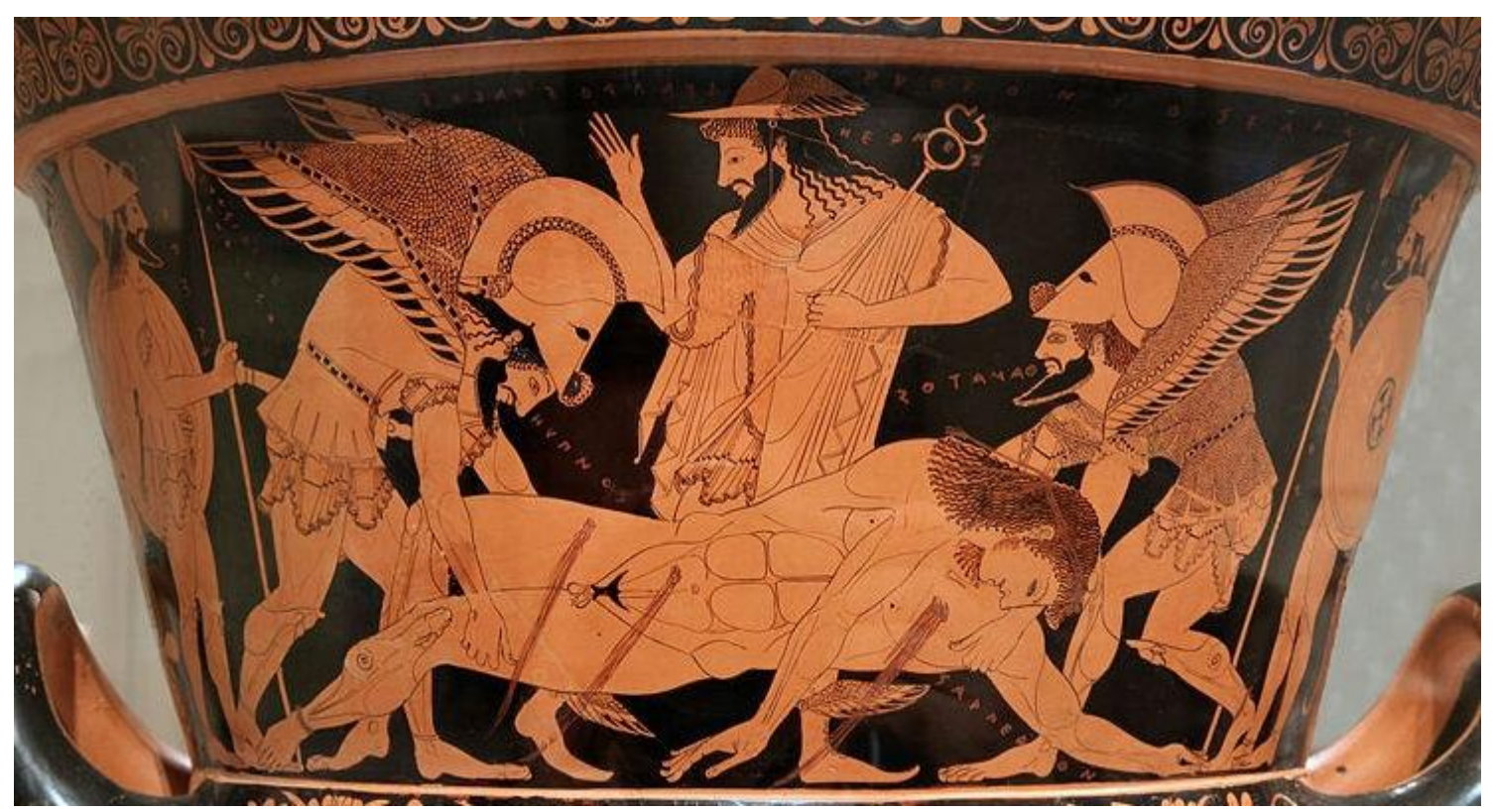

Fig. 1 - Hermes, Hipnos e Thânatos

\section{Hermes, Hipnos e Thânatos}

Detalhe de cálice-cratera ática de figuras vermelhas de Eufrônio (pintor) e Euxíteos (ceramista)

Data: c. -515

New York, The Metropolitan Museum of Art

Créditos: "Howcheng", 2008

A cena se refere ao famoso episódio da Guerra de Tróia em que Zeus ordena que o sono (Hipnos) e a morte (Thânatos), aqui representados com asas, recolham o cadáver de Sarpédon (Il. 16.666-75), filho que teve com Laodâmia, filha do herói Belerofonte. Hermes, no centro da cena, usa um pétasos, o chapéu dos viajantes, e tem nas mãos o kerikeion, símbolo dos arautos e mensageiros gregos; por baixo do corpo de Sarpédon vê-se as sandálias aladas. Exceto pelas asas, Hipnos e Thânatos se assemelham a qualquer outro guerreiro. Na Fig. 0110a, a cena vista de longe. ${ }^{319}$

\footnotetext{
${ }^{318}$ EURÍPIDES, Alceste, trad. Junito de Souza Brandão, Rio de Janeiro, Bruno Buccini, 1968, p. 124 e 125.

${ }^{319}$ RIBEIRO, W. A., Hermes, Hipnos e Thânatos. Portal Graecia Antiqua, São Carlos.

Disponível em WWW.greciantga.org/ima/index.asp?num=011o. Consulta: 12/10/2009.
} 


\section{ANEXO B - MITO, THÂNATOS E PSICOLOGIA}

$\mathrm{Na}$ década de 30, Freud irá estabelecer, em Além do princípio de prazer ${ }^{320}$, uma conexão entre os princípios antagônicos Thânatos e Eros, sendo o primeiro considerado como pulsão de morte, e o segundo, pulsão de vida. Na psicanálise freudiana, um mito completa o outro.

Ao falar sobre os elementos estruturais do mito, no livro Ensaio sobre o homem, Ernst Cassirer se posiciona contrariamente à teoria psicanalítica de Freud, quando esta declara que “todas as produções míticas são variações e disfarces de um único e mesmo tema psicológico - a sexualidade" ${ }^{321}$. Cassirer ressalta que, desde o início, o mito combina um elemento teórico e um elemento de criação artística, estabelecendo a sua "íntima" ligação com a poesia:

O que nos impressiona, em primeiro lugar, é a sua íntima associação com a poesia. "O mito antigo", disseram, "é a 'massa' a partir da qual a poesia moderna cresceu lentamente mediante os processos que os evolucionistas chamam de diferenciação e especialização. A mente do criador do mito é o protótipo; e a mente do poeta... ainda é essencialmente mitopoética". ${ }^{322}$

Ernst Cassirer lembra Kant quando este diz que, na contemplação estética, é indiferente à existência ou não-existência de seu objeto, mas que na "imaginação mítica está sempre implicado um ato de crença". Ressalta ainda uma importante colocação sobre a visão do mito que dos que o consideram como:

(...) tipicamente etiológicos ou explicativos (...) Não podemos reduzir o mito a certos elementos estáticos fixos; devemos esforçar-nos par apreendê-los em sua vida interior, em sua mobilidade e versatilidade, em seu princípio dinâmico ${ }^{323}$.

\footnotetext{
${ }^{320}$ FREUD, Sigmund. Além do princípio de prazer. Trad. Christiano Monteiro Oiticica. Rio de Janeiro: Imago, 2003.

${ }^{321}$ CASSIRER, Ernst. Ensaio sobre o homem. Trad. Tomás Rosa Bueno. São Paulo: Maritns Fontes, 2005, p. 126.

${ }^{322}$ Ibidem. p. 126.

${ }^{323}$ Ibidem. p. 127.
} 


\section{ANEXO C - POLVO NA CERÂMICA GREGA.}

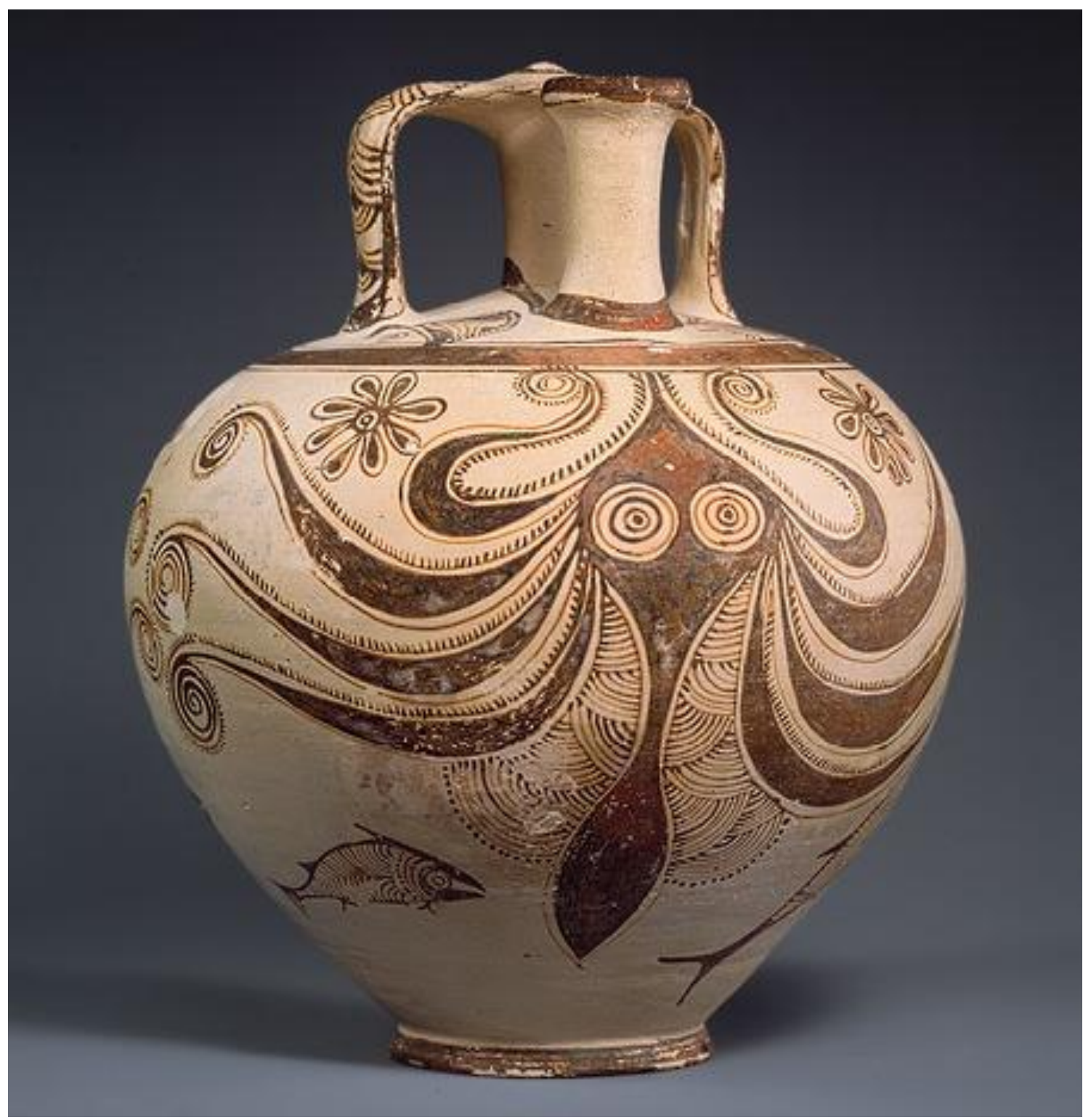

\section{Jarro micênico com polvo estilizado}

Data: $-1200 /-1100$

New York, The Metropolitan Museum of Art

http://greciantiga.org/img/index.asp?num=0638 acesso em 08/10/2010.

Uma das possíveis representações do desenho de um polvo na cerâmica minóica retratada pela poeta Sophia Andresen no poema "Epidauro" do livro Geografia ${ }^{324}$, analisado no capítulo terceiro.

$\overline{324}$ ANDRESEN, Sophia de Mello Breyner. Geografia. Lisboa: Caminho, 2004, p. 65. 


\section{ANEXO D- O HOMEM VITRUVIANO}

Leonardo Da Vinci teria feito o desenho no ano de 1490, e faz parte da coleção “Gallerie dell'Accademia", na cidade de Veneza, Itália. A união dos interesses de Leonardo pela ciência e pela arte da proporção é representada neste famoso desenho, em que duas imagens sobrepostas de um homem nu estão contidas em um círculo e um quadrado. No desenho, as posições dos braços e pernas expressam quatro posturas diferenciadas inscritas em círculo, sendo o centro da figura o umbigo. ${ }^{325}$

A inspiração para este desenho veio do tratado De Architectura, do arquiteto romano Marcus Vitruvius Pollio. A obra defendia que os edifícios deveriam se basear na simetria e proporção da forma humana. Segundo o arquiteto, o corpo humano, com os braços e pernas estendidos, se ajustava perfeitamente ao círculo e ao quadrado.

Muitos artistas da Renascença tentaram traçar o ideal de Vitruvius, façanha plenamente realizada por Leonardo. O desenho talvez seja um dos mais famosos de seu legado. Nele, ele insere suas próprias observações sobre a forma humana, corrigindo algumas medidas inconsistentes de Vitruvius.

O conceito elabora a noção a respeito da divina proporção através do raciocínio matemático, sendo um modelo ideal para todo o ser humano. As proporções do "homem vitruviano" são perfeitas e inserem o conceito clássico e divino de beleza.

As descrições de Vitrúvio foram se perdendo no decorrer dos anos e as cópias fugindo do traço original, dentre tantos desenhos, ficando a representação gráfica de Da Vinci a mais difundida no momento atual.

\footnotetext{
${ }^{325}$ <http://www.infoescola.com/desenho/o-homem-vitruviano/>. Acesso em 08/10/2010.
} 


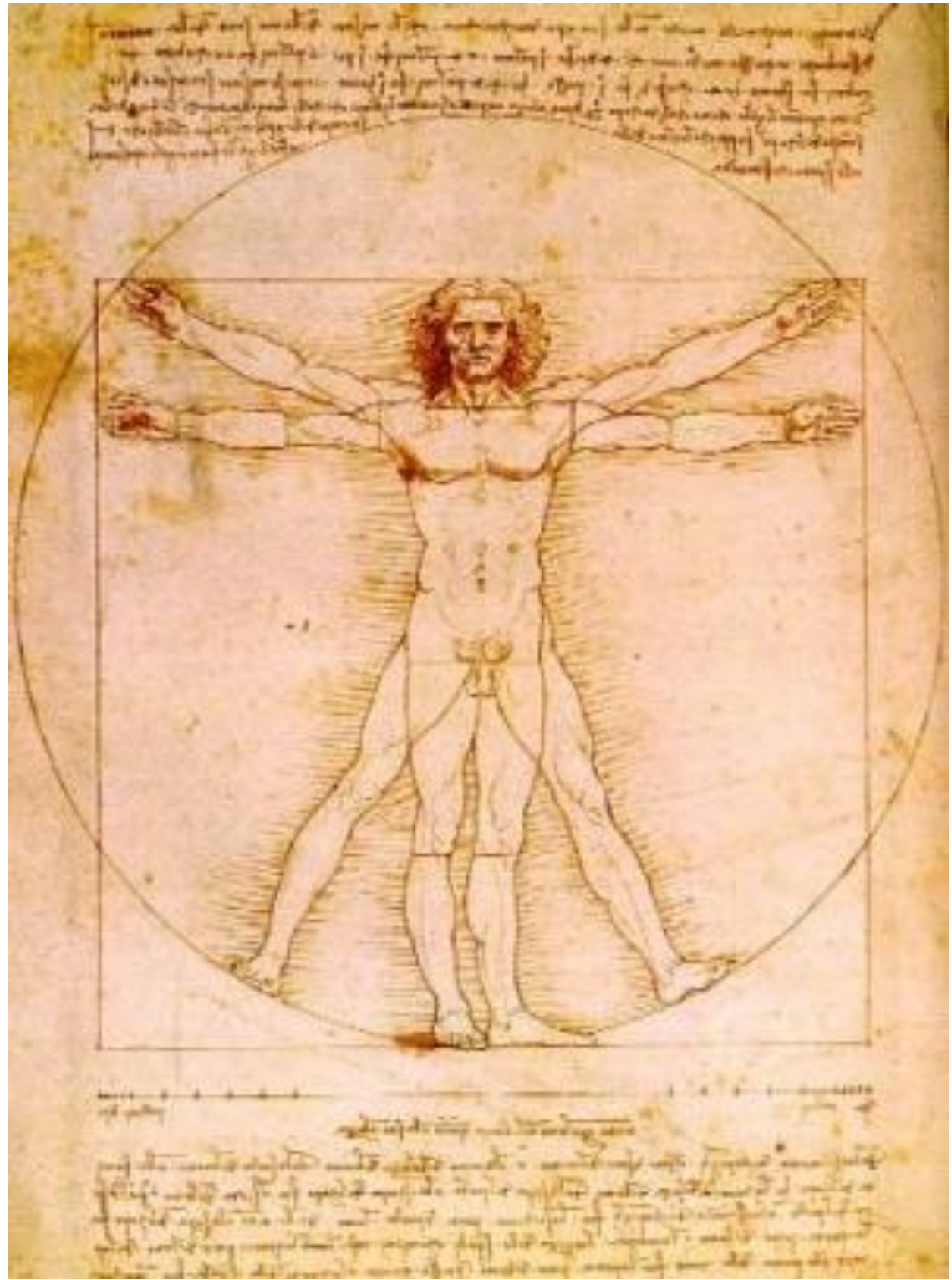

O Homem Vitruviano - Leonardo da Vinci

Data - 1490

Gallerie dell'Accademi

Veneza, Itália.

http://commons.wikimedia.org/wiki/File:Anatomia_homem_leonardo.jpg acesso em $13 / 11 / 2010$. 


\section{ANEXO E - CLITEMNESTRA}

Segundo Junito de Souza Brandão ${ }^{326}$ Clitemnestra (g. Klytaimnestra) era filha de Tíndaro e de Leda, irmã de Helena. Clitemnestra desposou primeiro Tântalo, filho de Tieste, porém Agamêmnon matou-o assim como a um filho do casal. Casou-se contra a sua vontade com ele e teve desse casamento Ifigênia, Electra, Crisôtemis e Orestes.

Após o sacrifício de Ifigênia em Áulis, para proporcionar os ventos, por ocasião da partida das naus gregas para Tróia, ela que jamais perdoou ao marido o assassinato de Tântalo e de seu filho, Clitemnestra passou a odiar Agamêmnon. Durante a ausência do marido tornou-se amante de Egisto. Os dois tramaram o assassinato do rei de Esparta, "Na versão épica da lenda (a mais antiga), Clitemnestra não participou do crime, praticado exclusivamente por Egisto"327. Na tragédia, além de Agamêmnon, Clitemnestra também matou (ou ajudou a matar) Cassandra, no dia da chegada de ambos a Micenas, após a guerra de Tróia. Astuta, recebeu o rei com todas as honras devidas a um herói. Na belíssima recriação poética de Ésquilo (...), a rainha acolhe o esposo com palavras perpassadas de cinismo, fazendo-o caminhar por sobre um tapete púrpura. O ódio de Clitemnestra estendeuse aos filhos tidos com Agamêmnon, principalmente Orestes e Electra. Sete anos após o crime de sua mãe, Orestes assassinou-a e matou Egisto, com a ajuda de Electra.

Clitemnestra tinha o dom e o domínio da palavra conforme nos indicam os seguintes trechos:

CORIFEU: "Senhora, aos deuses dirigirei mais tarde as minhas preces. Entretanto gostaria de ouvir e admirar de novo a história que acabas de contar, do princípio ao fim." [...] "Senhora, falas com a sensatez de um homem sábio".

CLITEMNESTRA: "De prazeres adúlteros ou sequer má reputação sei tanto como de temperar o bronze." [...] "Estai a experimentar-me como se eu fosse uma mulher insensata, mas falo-vos, comum coração que, como sabeis, não conhece o medo.”

CLITEMNESTRA: “Sim, mas um homem que não é invejado não é invejável. [...] Cede. És tu, afinal, que vences, se a vitória me for dada por ti”. ${ }^{328}$

\footnotetext{
${ }^{326}$ BRANDÃO, Junito de Souza. Mitologia Grega Vol. III. Petrópolis: Vozes, 2007, p. 330.

327 KURY, Mário da Gama, Dicionário de Mitologia Grega e Romana, 4a ed., Rio de Janeiro:Jorge Zahar Editor, 1991, p. 87.

328 ÉSQUILO, Agamémnon, trad. Manuel de Oliveira Pulquério, Rio de Janeiro: Edições 70, 199., p. 38; 40; 49; $88 ; 62$.
} 


\section{ANEXO F - ELECTRA}

Segundo Junito de Souza Brandão, em grego "Eléktra, da raiz indo-européia ulek, sânscrito ulkã, 'meteoro, incêndio', é a brilhante, a que se incendeia de ódio" ${ }^{329}$. Filha de Agamêmnon e Clitemnestra. Após a morte de Agamêmnon por Egisto e Clitemnestra, Electra, com seu temperamento forte, rebelou-se contra a mãe. Foi transformada em escrava do palácio por Egisto. Ela salvou o irmão, Orestes, da morte, entregando-o ao velho preceptor da família. Mais tarde, com palavras cheias de ódio, Electra incentivou Orestes a matar Egisto e "guiou-lhe o punhal contra o seio da própria mãe." 330

Jean-Pierre Vernant descreve Electra como um duplo de Clitemnestra:

(...). Ocupando junto do seu jovem irmão o lugar dessa mãe de quem herdou a natureza viril e dominadora, Electra 'duplo' de Clitemnestra, é ao mesmo tempo o seu oposto. Virgem (...) ela quer ser tanto mais casta quanto mais sensual e desavergonhada lhe parece sua mãe. Ama seu pai de modo tão apaixonado quanto Clitemnestra odeia o seu esposo. ${ }^{331}$

Trechos do drama Electra de Esquilo:

ELECTRA: Pode haver ponderação no desespero?

Dizei: é justo negligenciar os mortos.

CRISÔTEMIS: Não Percebestes que és mulher, que não és homem?

CORO: Electra, abandonada, enfrenta só a tempestade,

(...) A própria morte não lhe causa medo. ${ }^{332}$

Trechos do drama Electra de Eurípides:

ELECTRA: Pois sofro; mas em breve a fúria amaina. (...)

Sou responsável pelo horror do excesso.

A fúria me incendiou ${ }^{333}$

\footnotetext{
${ }^{329}$ BRANDÃO, Junito de Souza. Mitologia Grega Vol.III, Petrópolis: Vozes, 2007, p. 342.

${ }^{330}$ Idem. Dicionário Mítico-Etimológico da Mitologia Grega. Petrópolis: Vozes, 1993, p. 325.

331 VERNANT, Jean-Pierre. Mito e Pensamento Entre os Gregos. Trad. Haiganauch Sarian. São Paulo: Paz e Terra, 2002, p. 205.

${ }^{332}$ SÓFOCLES. Electra. Trad. Mario da Gama Kury, Rio de Janeiro, Civilização Brasileira, 1965, p. 8-39-44.

${ }^{333}$ EURÍPIDES. Electra. Trad. Trajano Vieira, São Paulo: Ateliê Editorial, 2009, p. 123-125.
} 


\section{ANEXO G - METAMORPHOSES}

Este é trecho do poema "Metamorphoses" de Ovídio (aqui com a tradução datada de 1931 de J. C.), do qual Sophia Andresen adaptou o poema "Medeia", analisado no capítulo terceiro:

\section{II - Jasão pede a Medêa que remoce Eson, seu pae}

As mães hemonias (da Thessalia) e os Paes (já) velhos levam presentes por terem recuperado seus filhos, e queimam (derretem) na chamma o incenso amontoada e a victima votada, os chifres cobertos de ouro tombou. Mas Esón já mais perto da morte e fatigado de annos, está ausente da multidão que o felicita. Então o filho de Eson falla assim: O' minha esposa, a quem confesso dever minha salvação, ainda que me deste tudo, e que o conjunto dos teus serviços excedeu a minha esperança, comtudo se os encantamentos podem obter isto (de facto o que não podem elles?) tira dos mues annos e dá a meus paes estes annos tirados. E não conteve as suas lagrimas. Ella foi abalada pelo amor filial de quem pedia, e Eeta por ella abandonado apresentou-se a seu coração differente, sem contudo confessar seus affectos (seus sentimentos). O' meu esposo, disse ella, que crime sahiu da tua bocca? Parace-te então que eu possa prolongar a quem quer que seja o espaço da sua vida? Hecate não permitiria isto, nem tu pedes cousa justa, mas, ó Jasão, experimentarei dar-te um presente maior do que este que me pedes. Tentarei dar ao sogro uma longa existência por meio da minha arte, não por meio dos teus annos: só que a deusa de três formas (Hecate) nos ajude e propicia favoreça esta grande empreza. Tres noite faltavam para que os chifres inteiros se reunissem e formassem um globo perfeito ( $a$ lua cheia). Depois que a lua (estando) muito cheia brilhou e olhou as terras com sua face inteira, ella (Medêa) sahe da sua habitação, vestida de um roupa não cingida, descalça dum pé, sendo espalhado sobre os hombros seus cabellos soltos, e sem ser acompanhada leva seus passos errantes pelos profundos silêncios da meia noite. Profundo somno havia extendido os homens e as aves e as feras; s sebes com nenhum murmúrio e as folhas immoveis e o ar humido calam-se; só as estrellas brilham. E ella estendendo seus braços para ellas voltou-se três vezes, três vezes banhou o seu cabello com água tirada do rio e abriu sua boca com taes urros e abaixou seu cotovello sobre a dura terra.

\section{III. - Invocação de Medêa. Eson é rejuvenecido}

O' noite, diz Ella, muito fiel aos mysterios, e vós, ó astros áureos que succedeis com a lua aos fogos do dia, e tu, ó Hecate de três cabeças, que vens como cúmplice e ajudante das nossas empresas; e vós, ó encantamentos e artes das magas, e tu, ó terra que forneces ás magas hervas poderosas, e vós, todos, ó deuses das florestas, e vós todos, ó Deuses da noite, vinde em meu soccorro; vós, com o auxílio dos quaes, 
quando eu quis, os rios voltaram para suas nascentes admirando-se as margens; eu acalmo com meus encanntamentos os mares encapelados, agito (os mares) immoveis, eu trago as nuvens, afungento e chamo os ventos, quebro com minhas palavras e com meus cantos as gargantas das víboras, e movo os rochedos inteiros e os carvalhos arrancados das usas terras, e as florestas; eu faço tremer as montanhas e mugir o solo e cahir os manes dos sepulcros; vós me amortecestes as chamas dos touros e opprimistes com a charrua curva seu pescoço intolerante de todos peso; vós destes aos homens nascidos da terra guerras cruéis contra si mesmos e vós adormecestes o guarda falta somno, e enviastes o ouro (o velocino de ouro) para a cidade da Grécia, tendo enganado o guarda (deste ouro).

Agora há necessidade se succos, para que com elles a velhice torne á flor (da edade), e retome seus primeiros annos. E vós ( $m$ ’os) dareis; pois os astros não brilharam em vão, nem chega em vão o carro puxado pelo pescoço dos alados dragões. O carro descido do céu havia chegado. E assim que (Medêa) montou nelle (no carro) e que afagou o pescoço dos dragões enfreiados e que com suas mãos sacudiu as leves rédeas, é levada pelos ares e avista do alto a Tempe da Thessalia, collocada debaixo della, e dirige os dragões da Thracia na direcção destas regiões, e examina as ervas que produziu o Ossa; as que produziram o alto Pelion e o Othrys, e o Pindo e o Olympo maior que o Pindo e arranca pelas raízes umas que lhe agradam, corta outras com a curvatura da sua foice de bronze. E o nono dia e a nona noite já a tinham visto percorrer todos os campos sobre o carro e sobre as azas dos dragões, quando ella regressou e os dragões não tinham sido tocados, senão pelo cheiro das hervas e comtudo depuzeram a pelle da sua antiga velhice. ${ }^{334}$

${ }^{334}$ NASO, Publio Ovidio. Trechos das Metamorphoses. Trad. J. C. São Paulo: Livraria Salesiana, 1931, p. 181187. 